\title{
Abstention In Constitutional Cases: The Scope of the Pullman Abstention Doctrine
}

\section{Citation}

Martha A. Field Abstention In Constitutional Cases: The Scope of the Pullman Abstention Doctrine, 122 U. Pa. L. Rev. 1071 (1974).

\section{Published Version}

http://scholarship.law.upenn.edu/penn_law_review/vol122/iss5/1/

\section{Permanent link}

http://nrs.harvard.edu/urn-3:HUL.InstRepos:12956311

\section{Terms of Use}

This article was downloaded from Harvard University's DASH repository, and is made available under the terms and conditions applicable to Other Posted Material, as set forth at http:// nrs.harvard.edu/urn-3:HUL.InstRepos:dash.current.terms-of-use\#LAA

\section{Share Your Story}

The Harvard community has made this article openly available.

Please share how this access benefits you. Submit a story.

Accessibility 


\title{
University of Pennsylvania
}

\section{Law Review}

\section{FOUNDED 1852}

\section{Formerly}

American Law Register

\begin{tabular}{lll}
\hline \hline VOLUME 122 & MaY 1974 & Number 5 \\
\hline \hline
\end{tabular}

\section{ABSTENTION IN CONSTITUTIONAL CASES: THE SCOPE OF THE PULLMAN ABSTENTION DOCTRINE}

\author{
Martha A. Field $\dagger$
}

TABLE OF CONTENTS

INTRODUCTION 1074

I. The Background of the Pullman Doctrine ...... 1074

II. The PUllmaN CASE ........................................... 1077

III. The ENGLAND Procedure .................................. 1078

PART ONE: THE CASES IN WHICH PULLMAN ABSTENTION IS PROPER .................................. 1080

I. Allowing State Courts to Rule on Federal Constitutional Issues-An Improper Purpose FOR ABSTENTION

II. Allowing State Courts to Decide State Issues -A Proper Purpose in Some Instances

$\dagger$ Associate Professor of Law, University of Pennsylvania. A.B. 1965, Radcliffe College; J.D. 1968, University of Chicago Law School. Member, District of Columbia Bar.

I wish to express my appreciation to Ms. Susie Millman for her extensive assistance with this article. 
A. The Advantages of Abstaining for State Court Decision of State Issues and Its Costs 1084

B. The Proper Application of Existing Requirements That State Law Be Unclear and Be Susceptible to an Interpretation That Will Avoid a Federal Constitutional Question

1. The Importance of a Significant Lack of Clarity in the State Law Issue

2. An Analysis of the Reasons for Abstaining for State Court Decision of Unclear State Issues

a. Avoiding Interference With a Legitimate State Program

b. Avoiding Unnecessary Decision of Federal Constitutional Issues

3. The Operation of These Policies in "Authorization Cases"

a. The Importance of Identifying the Policy That Abstention Will Serve in the Particular Case

b. Cases in Which Abstention Serves to Avoid Disrupting a Legitimate State Program ... 1104

c. Cases in Which Abstention Serves to Avoid Unnecessary Federal Constitutional Adjudication

d. Cases Involving Clear and Nonsensitive Federal Constitutional Questions

4. The Justification for Requiring Federal Decision of the State Law Issue Prior to the Abstention Decision

5. The Application of the Abstention Principles to "Construction Cases"

a. The Need to Decide the State Law Issue Prior to the Federal Issue

b. The Interaction of the Abstention Policies in Construction Cases

c. Abstention in Cases of Clear Federal Unconstitutionality to Allow the State to Save Its Program

d. The State's Ability to Correct Some Erroneous Decisions Through Administrative Action 
6. The Application of the Abstention Policies in Cases Apparently Involving Construction in Which Conduct Under Authority of the Ambiguous Provision Is Also at Issue

7. Summary of Suggested Rules for Applying Current Requirements That State Law Be Unclear and That It Be Susceptible to an Interpretation That Would Avoid a Federal Constitutional Question

a. Authorization Cases

b. Construction Cases

c. Construction Cases in Which Conduct 1128 Under the Ambiguous Enactment Is Also at Issue

C. A Countervailing Factor-The Relevance of a Public Interest in Swift Adjudication of the Federal Constitutional Issue

D. Conclusion Regarding Proposed Application of Existing Factors Relating to Unclear State Law and the Nature of the Federal Constitutional Issue .....

E. A Proposal to Abandon the Requirement That the Case Must Contain a Federal Constitutional Issue

F. Possible Additional Pullman Requirements

1. A Requirement That the Suit Be One to Enjoin State Action

2. The State's Consent as a Precondition of Abstention

a. A Requirement That State Officials Consent to Abstaining in the Particular Case

b. A Requirement of Adequate State Remedies

PART TWO: THE RELATION OF PULLMAN ABSTENTION TO OTHER TYPES OF ABSTENTION

I. "ThIBODAUX ABSTENTION"

II. Administrative Abstention

III. The Dombrowski-Younger Line of Cases 


\section{INTRODUCTION}

\section{The Background of the PulLMan Doctrine}

The eleventh amendment to the United States Constitution provides:

The Judicial power of the United States shall not be construed to extend to any suit in law or equity, commenced or prosecuted against one of the United States by Citizens of another State, or by Citizens or Subjects of any Foreign State. ...

Though the amendment does not in terms so state, it has been established that states are similarly protected against suits by their own citizens. ${ }^{1}$ Moreover the protection extends beyond suits against states as such to cover actions in which persons acting as state officials are named as defendants. ${ }^{2}$ Thus it would appear that individual litigants may never sue a state without its consent.

In 1908, however, in Ex parte Young, ${ }^{3}$ the Supreme Court severely qualified this protection ${ }^{4}$ by holding that a suit against a state officer alleged to be acting unconstitutionally. is not a suit against the state. Its "reasoning" was that a state official cannot be acting on behalf of the state when he acts unconstitutionally. ${ }^{5}$ The same rationale would seem to exempt the

' Hans v. Louisiana, 134 U.S. 1 (1890).

2 Governor of Ga. v. Madrazo, 26 U.S. (1 Pet.) 110, 122-23 (1828) (Marshall, C.J.). Chief Justice Marshall had earlier held that the eleventh amendment protects the state only when the state is the named defendant, Osborn v. Bank of the United States, 22 U.S. (9 Wheat.) 738, 846, 857 (1824), but his position in Madrazo, apparently altering that aspect of Osborn, has since been settled doctrine. The amendment would be of little avail if it did not apply to suits against state officials. The case law is less than clear, however, on when an individual acts as a state official and when he acts in his private capacity. See, e.g., Georgia R.R. v. Redwine, 342 U.S. 299 (1952); In re Ayers, 123 U.S. 443 (1887).

3209 U.S. 123 (1908).

- Although Young is the case that has come to symbolize the doctrine, there were earlier cases tending in the same direction. See, e.g., Prout v. Starr, 188 U.S. 537 (1.903); Smyth v. Ames, 169 U.S. 466 (1898); Reagan v. Farmers' Loan \& Trust Co., 154 U.S. 362 (1894).

s In Ex parte Young the Court said:

[T] he use of the name of the State to enforce an unconstitutional act to the injury of complainants is a proceeding without the authority of and one which does not affect the State in its sovereign or governmental capacity. It is simply an illegal act upon the part of a state official in attempting by the use of the name of the State to enforce a legislative enactment which is void because unconstitutional. If the act which the state Attorney General seeks to enforce be a violation of the Federal Constitution, the officer in 
states from the prohibitions of the fourteenth amendment and other constitutional provisions regulating only state action. ${ }^{6}$ Nevertheless, the Court has held that acts of state officials can violate those constitutional provisions as acts of the state. ${ }^{7}$ The two doctrines in combination enabled individual litigants to question the constitutionality of state actions in federal court, even where the state had not consented to suit. They thereby significantly facilitated enforcing state compliance with federal constitutional standards. ${ }^{8}$ At the same time, the

proceeding under such enactment comes into conflict with the superior authority of that Constitution, and he is in that case stripped of his official or representative character and is subjected in his person to the consequences of his individual conduct. The State has no power to impart to him any immunity from responsibility to the supreme authority of the United States. ...

209 U.S. at $159-160$.

${ }^{6}$ Another difficulty with the rationale is how, given the usual principles for construing the statutory federal question jurisdiction, see Louisville \& N.R.R. v. Mottley, 211 U.S. 149 (1908), these cases are deemed to "arise under" the Constitution when the official character of the action is raised only as justification and the invalidity of the statutory authority only by reply to that justification.

${ }^{7}$ Home Tel. \& Tel. Co. v. Los Angeles, 227 U.S. 278 (1913). The Court there said:

[I] may not be doubted that where a state officer under an assertion of power from the State is doing an act which could only be done upon the predicate that there was such power, the inquiry as to the repugnancy of the act to the Fourteenth Amendment cannot be avoided by insisting that there is a want of power. That is to say, a state officer cannot on the one hand as a means of doing a wrong forbidden by the Amendment proceed upon the assumption of the possession of state power and at the same time for the purpose of avoiding the application of the Amendment, deny the power and thus accomplish the wrong. To repeat, for the purpose of enforcing the rights guaranteed by the Amendment when it is alleged that a state officer in virtue of state power is doing an act which if permitted to be done prima facie would violate the Amendment, the subject must be tested by assuming that the officer possessed power if the act be one which there would not be opportunity to perform but for the possession of some state authority.

227 U.S. at 288-89. Home Tel. \& Tel. thus goes beyond contradicting the Young rationale-which seemingly would exempt states from the fourteenth amendment even when the state instigates or directs the unconstitutional action and its courts expressly approve it-and deems even actions that the state apparently prohibits to be state action within the fourteenth amendment. Some actions on the part of officials, however, are considered individual rather than state conduct. See note 2 supra. See also United States v. Raines, 362 U.S. 17, 25-26 (1960); Mosher v. City of Phoenix, 287 U.S. 29 (1932).

${ }^{8}$ If one were not permitted to sue state officers for violating the Constitution, the most obvious way to raise constitutional issues would be in defense of a criminal prosecution. For a discussion of that and other possible methods of enforcing the Constitution against the states, see H. Hart \& H. Wechsler, The Federal Courts and the Federal System 936-37 (2d ed. 1973) and C.A. Wright, Federal Courts, 185-86 (2d ed. 1970). See also Louisiana v. Jumel, 107 U.S. 711, 750-52 (1883) 
doctrines made possible substantial federal court interference with state programs by making every program, whether it was longstanding or newly enacted and not yet launched, subject to constitutional attack in the federal courts and to issuance of an injunction against its execution or continuation. Even if the federal system ultimately sustained the validity of the program, interlocutory orders delaying its enforcement could cause irreparable damage to state policy. ${ }^{9}$

Congress rejected legislative proposals to overturn entirely the new federal jurisdiction. ${ }^{10}$ But over a period of years it passed a number of bills designed to cut down on the adverse effects on the execution of state policy that Ex parte Young had made possible. The most significant of these bills took from the federal courts all power to enjoin state rate orders and tax collections so long as "a plain, speedy and efficient remedy" is available in the courts of the state; ${ }^{11}$ and required a district court of three judges to pass upon attempts to enjoin state statutes or administrative orders on constitutional grounds, with direct Supreme Court review of their decisions. ${ }^{12}$

The courts joined with Congress in imposing limitations upon the situations and the manner in which injunctions against state officials should issue. One of the most important court-imposed limitations has come to be known as "the Pullman doctrine" from the case in which it was first fully articulated. ${ }^{13}$ The doctrine concerns the federal courts' abstention in certain constitutional cases from the exercise of jurisdiction that Young and ensuing congressional statutes would seem to allow to them.

(Harlan, J., dissenting). Professor Wright concludes that "in perspective the doctrine of Ex parte Young seems indispensable to the establishment of constitutional government and the rule of law." C.A. WRIGHT, supra at 186.

${ }^{9}$ In an era when state economic regulation was often found vulnerable to due process attack, the new federal jurisdiction was especially disruptive.

${ }^{10}$ See, e.g., 45 Cong. REc. 7256 (1910) (remarks of Senator Overman); 42 Cong. Rec. 4848-49 (1908); F. Frankfurter \& J. Landis, The Business of the Supreme Court 143 (1928). (1970).

${ }^{11}$ Johnson Act, 28 U.S.C. $\S 1342$ (1970); Tax Injunction Act, 28 U.S.C. § 1341

12 The original three-judge court act applied only to state statutes and not administrative orders. 36 Stat. 557 (1910). It was codified as $\$ 266$ of the 1911 Judicial Code. The provision has been modified in several respects over a period of years. See H. HART \& H. WECHSLER, supra note 8 at 967-68. The current version is 28 U.S.C. $\$ 2281$ (1970).

${ }^{13}$ Railroad Comm'n v. Pullman Co., 312 U.S. 496 (1941). Cases that might be deemed precursors to Pullman can be found in H. HART \& H. WECHSLER, supra note 8 at $988-89$. 


\section{The Pullman Case}

Railroad Commission of Texas v. Pullman Co. ${ }^{14}$ involved a challenge to an order of the Texas Railroad Commission that all sleeping cars operated by railroads in Texas must be in the charge of a Pullman conductor. Prior to the Commission's order, trains with only one sleeping car had been in the charge of a porter instead of a conductor. Porters were black, conductors white. The order was attacked ${ }^{15}$ on the grounds that it violated the commerce, due process and equal protection clauses $^{\mathbf{1 6}}$ of the Federal Constitution and that it was invalid under Texas law. A three-judge district court held that the Texas statute which gave the Commission power over railroads and which made it "the duty of the said Commission ... to correct abuses and prevent unjust discrimination in the rates, charges and tolls of such railroads ... . and to prevent any and all other abuses in the conduct of their business . . ."17 did not authorize the Commission to issue the order as the correction of an "abuse," and the court enjoined enforcement of the Commission's order on that ground. ${ }^{18}$ On direct review the Supreme Court held, in an opinion by Justice Frankfurter, that the district court should have abstained from deciding the case.

Although Pullman was within the original federal jurisdiction as a federal question case, jurisdiction also extended to the ancillary state issue. ${ }^{19}$ In fact, the Supreme Court had suggested that in such cases federal courts should decide the state questions first if, as in Pullman, doing so might avoid a federal constitutional decision. ${ }^{20}$ The difficulty in Pullman was that, according to Justice Frankfurter, Texas law was "far from clear."21 It is true that the language of the Texas statute did not permit a confident determination whether or not the

14312 U.S. 496 (1941).

15 The complainants were the Pullman Company and the affected railroads. The porters intervened as complainants and the conductors intervened in support of the order. $I d$. at 498 .

${ }^{16}$ The fourteenth amendment challenges were both that the order was unjust and arbitrary and that it discriminated against Blacks.

17312 U.S. at 499 n.1.

${ }^{18}$ Pullman Co. v. Railroad Comm'n, 33 F. Supp. 675 (W.D. Tex. 1940).

${ }^{19}$ See Siler v. Louisville \& N.R.R., 213 U.S. 175, 191 (1909).

${ }^{20}$ See. e.g., Cincinnati v. Vester, 281 U.S. 439 (1930); Greene v. Louisville \& Interurban R.R., 244 U.S. 499, 508, 519 (1917); Siler v. Louisville \& N.R.R., 213 U.S. 175,193 (1909).

21312 U.S. at 499. 
Commission's order was within its purview. ${ }^{22}$ Justice Frankfurter said as well that Texas decisions interpreting the statutory language did not clarify the issue. ${ }^{23}$ On that assumption, a federal court that follows the policy of deciding state issues first runs a high risk of deciding those questions erroneously. If it erroneously holds the order authorized, it will needlessly reach the federal constitutional questions. ${ }^{24}$ If it erroneously holds that the order is unauthorized, it will avoid for the moment deciding the constitutional questions, but only at the risk of improvidently enjoining an ostensibly valid state program. Moreover, if the state courts subsequently expose the error by deciding the state question differently, the federal decision will be subject to reopening. ${ }^{25}$ If it is reopened, the federal constitutional questions may then have to be litigated. Therefore, although the Supreme Court in Pullman did not find the district court's "forecast of Texas law" unreasonable, it concluded that only the course of abstaining in favor of the state judicial system could "avoid [both] the waste of a tentative decision [and] . . . the friction of a premature constitutional adjudication." 26

\section{The ENGLAND Procedure}

The Pullman Court indicated its belief that abstention would not prejudice the complainants' federal constitutional claims, ${ }^{27}$ but it did not make explicit whether those claims would ultimately be decided in state or in federal court. ${ }^{28}$

${ }^{22}$ The statutory language provides little guidance concerning the limits of the Commission's power to correct "abuses." Justice Frankfurter also raised the possibility that the order might be authorized under the Commission's power to correct "discrimination." It seems plain on the face of the statute, however, that the power to prevent "unjust discrimination" is limited to railroads' "rates, charges and tolls"-although in quoting from the statute in the body of the opinion the Justice omitted the reference to "rates, charges, and tolls." 312 U.S. at 498 \& n.1, 499.

${ }^{23}$ In fact such decisions, which the district court had relied upon, were relatively unambiguous, indicating that to be correctible by the Commission an "abuse" must be defined as such by law. Pullman Co. v. Railroad Commission, 33 F. Supp. 675, 676-77 (W.D. Tex. 1940).

${ }^{24}$ If the court then held the order constitutional, the ultimate disposition of the controversy would also be erroneous.

${ }^{25}$ See, e.g., Lee v. Bickell, 292 U.S. 415 (1934); Glenn v. Field Packing Co., 290 U.S. 177 (1933).

26312 U.S. at 500 .

${ }^{27}$ Id. at 501 .

${ }^{28}$ There are suggestions in the opinion, however, that a return to the federal forum was contemplated. Justice Frankfurter speaks of the state setcling "the issue 
For a period after the Pullman decision, it remained unsettled whether the parties remanded to a state court should submit their federal as well as their state claims for the determination of that tribunal or whether they could reserve their federal claims for initial determination by the federal district court in case the state law questions did not in fact dispose of the controversy. ${ }^{29}$ In 1964 in England $v$. Louisiana State Board of Medical Examiners, ${ }^{30}$ the Supreme Court settled most questions about the procedure to be followed when Pullman abstention is ordered. It held that a litigant remanded to state court under that doctrine cannot be compelled to submit his federal claims for state court disposition; abstention may not be used to deprive him of the benefits of an initial federal determination of the federal issues and of the facts on which disposition of those issues depends. ${ }^{31}$ Although the litigant must inform state courts of the nature of his federal claims so that they may construe state law in light of them, he need not litigate the issues in state court. ${ }^{32}$ While prior to 1964 it was not clear whether the original federal forum was preserved for the litigants, and while that uncertainty may possibly have affected the disposition of some pre-1964 cases, the evaluation of the Pullman doctrine that follows, and the discussion of which cases require abstention, will proceed on the assumption that the England procedure is and was the rule. ${ }^{33}$

of state law." Id. at 501. Moreover, he directs the district court to retain jurisdiction over the controversy pending the state adjudication. Id. at 501-02.

${ }^{29}$ See, e.g., Wechsler, Federal Jurisdiction and the Revision of the Judicial Code, 13 Law \& Contemp. Prob. 216, 229 (1948). The later case of Government Employees v. Windsor, 353 U.S. 364 (1957), which held that litigants remitted to state courts must present their federal constitutional contentions so that state courts can interpret their law in the light of the constitutional claims, contributed to an impression that once the federal court has abstained, the state court to which the issue is delegated has jurisdiction of the whole controversy.

30375 U.S. 411 (1964).

31375 U.S. at 416-17. Accordingly, the federal district court should retain jurisdiction rather than dismiss when it orders abstention. See American Trial Lawyers Ass'n v. New Jersey S. Ct., 409 U.S. 467 (1973).

${ }^{32}$ A litigant may, however, submit his federal along with his state claims for decision in the state courts. If he does that, he is bound by the state court's decision and can have it overturned only by seeking review in the Supreme Court of the United States. 375 U.S. at 417-19. See NAACP v. Button, 371 U.S. 415, 427 (1963).

${ }^{33}$ One cannot sensibly discuss the proper scope for an abstention doctrine without making an explicit assumption concerning the abstention procedure, for the scope of the doctrine should vary with the procedure contemplated. Abstention for state court adjudication of federal as well as state claims, for example, might well be invoked in fewer or in different cases than abstention for state court determination of state issues alone. Under the American Law Institute's proposal regard- 


\section{PART ONE: THE CASES IN WHICH PULLMAN ABSTENTION IS PROPER}

\section{Allowing State Courts to Rule on Federal CONSTITUTIONAL ISSUES-AN IMPROPER Purpose For ABstention}

An abstention policy could serve several different purposes in cases involving the federal constitutionality of state enactments; the purpose intended will define the range of cases appropriate for abstention. One possible approach would allow state courts to rule on the validity of state enactments even when the only issues at stake were federal. The Pullman doctrine rather clearly does not adopt this approach. ${ }^{34}$ Nonetheless, it is necessary to examine its validity in order to deter-

ing abstention, for example, a case in which abstention is ordered will not, in the normal course, return to federal court, but instead will be fully decided within the state system subject only to possible review in the United States Supreme Court. The Institute recognizes that this fact makes abstention appropriate only when the district judge finds, inter alia, "that the parties' claims of federal right, if any, including [any] issues of fact material [thereto], can be adequately protected by review in the Supreme Court of the United States." AMERICAN Law Instrtute, Study of the Division of Jurisdiction Between State and Federal Courts 289 (1969) [hereinafter cited as ALI Study]. This limitation, according to the ALI commentary, will "ordinarily" bar abstention "[i]f there is a genuine issue of fact material to the federal contentions in the case." Id. 290. The conception then of the ALI procedure is to allow courts to remove entirely from the original federal jurisdiction cases that, though falling within a category of cases for which Congress has deemed federal jurisdiction necessary, do not on their facts show any need for federal jurisdiction. That conception is sufficiently different from the Pullman-England one, which allows each forum to adjudicate its own legal issues, that the ALI approach could supplement the current concept as readily as it could replace it.

Another change in procedures which would affect the proper scope of abstention would be the removal of some of the burdens abstention presently imposes on parties wishing to invoke federal jurisdiction. If, for example, a procedure were available for certification of a disputed state issue to the highest state court and if that procedure adequately met the needs for state court input in the particular case, then abstention might be more readily ordered than under the more cumbersome England procedure of requiring the plaintiff to initiate an action at the lowest state court level and to appeal the result through the state system before returning to the federal forum. Cf. Lehman Bros. v. Schein, 42 U.S.L.W. 4603 (U.S. Apr. 29, 1974).

${ }^{34}$ The Court has stated that "abstention cannot be ordered simply to give state courts the first opportunity to vindicate the federal claim." Zwickler v. Koota, 389 U.S. 241, 251 (1967). See also id. at 247, (quoting F. Frankfurter \& J. Landis, The Business of the Supreme Court 65 (1928)); McNeese v. Board of Educ. 373 U.S. 668, 672, 674 (1963). Cf. England v. Louisiana State Bd. of Medical Examiners, 375 U.S. 411, 415-16 (1964). Moreover, the England holding that parties may withhold federal issues from state tribunals when abstention is ordered clearly demonstrates that the purpose of abstention cannot be state decision of federal issues. That will nonetheless be an effect of abstention when the remanded party chooses to present his federal claims in state court. 
mine whether Pullman is undesirably narrow in this respect, especially since some members of the present Supreme Court appear to favor abstaining in some instances for state court determination of federal issues. ${ }^{35}$

A policy of abstaining for state adjudication of federal constitutional challenges to state action would be grounded in a concern both to relieve federal courts of congestion ${ }^{36}$ and to "steer around head-on collisions with the States by avoiding unnecessary constitutional decisions." 37 It would rest on the propositions that state courts are as capable of deciding these controversies as are federal courts, ${ }^{38}$ and that Supreme Court review would adequately protect federal rights.

Such a policy would undoubtedly reduce the workoad of the lower federal courts. It is less clear that federal-state comity would be promoted to any significant degree, since the premise of the policy is that transferring jurisdiction to state tribunals for decision of federal issues would not change the result of litigation. If federal, instead of state, tribunals void state legislation, doing simply what state tribunals would have been required to do had they heard the case, the harm to state interests, if any, is not any tangible damage but rather a harm to state pride. $^{39}$ Certainly any friction a federal court might create by properly deciding an issue of federal law is

${ }^{35}$ In Wisconsin v. Constantineau, 400 U.S. 433 (1971), Chief Justice Burger, in a dissenting opinion that Justice Blackmun joined, objected to the Court declaring a state statute unconstitutional without giving the Wisconsin courts the first opportunity to invalidate it under the state or federal constitutions. Id. at 440 . But see Lake Carriers' Ass'n v. MacMullan, 406 U.S. 498 (1972) (Burger, C.J., dissenting). See note 167 infra.

${ }^{36}$ See Wisconsin v. Constantineau, 400 U.S. 433, 443 (1971) (Burger, C.J., dissenting).

${ }^{37}$ Id. at 442 (Burger, C.J., dissenting).

${ }^{38}$ In Constantineau the Chief Justice said:

[N]o one could reasonably think that the judges of Wisconsin have less fidelity to due process requirements of the Federal Constitution than we do ....

Id. at 440 .

${ }^{39}$ And it is not in keeping with the current legal environment to expect a great blow to state pride from federal courts instead of state ones telling the states of the limitations the Federal Constitution imposes. It is true that there was an outcry in 1908 when Ex parte Young was decided. See 2 C. WARren, The Supreme Court in United States History 717 (1926). Today, however, people are accustomed to the notion that the federal government places limits upon the states. Moreover Young did more than say that federal courts rather than state ones could enjoin state officials' actions: Without its doctrine, state action often could not be invalidated at all (for the exceptions, see note 8 supra), for the eleventh amendment would protect the state from suit in both state and federal court. Young therefore affected tangible state interests, not solely state pride. 
far less serious than the friction that would result from it mistakenly deciding an issue of state law and, as a result, possibly voiding a state program that did not in fact transgress either state or federal bounds.

Moreover, using abstention to allow state courts to rule first on federal constitutional issues seems directly inconsistent with the general federal question jurisdiction ${ }^{40}$ and with Congress' rejection of proposals to delete from it suits challenging state enactments after it became clear that such suits were deemed within the jurisdiction. ${ }^{41}$ The subject under discussion is not whether it would be wise for Congress to alter jurisdictional statutes ${ }^{42}$ but rather how courts should apply the judgemade abstention doctrine. Congress' withdrawal from the federal jurisdiction of limited classes of suits against the statethose to enjoin state rate orders and tax collections, given "a plain, speedy and efficient remedy" in state court ${ }^{43}$ - supports the argument that using abstention to enlarge the exception would impinge upon Congress' domain.

A more limited extension of the congressionally enacted exceptions would call for deferral to a state system only when it had never passed on the constitutionality of the state statute at issue. ${ }^{44}$ While that use of abstention may seem a less direct repudiation of Congress' jurisdictional scheme than deferring to state courts for all constitutional challenges to state enactments, it would still remove some cases within congressional jurisdictional grants and would rest upon premises contrary. to those underlying current federal question jurisdiction. ${ }^{45}$

${ }^{40}$ Under the operative statutes the jurisdiction is concurrent with state jurisdiction, and either the plaintiff or the defendant may opt for the federal forum. See 28 U.S.C. $\S \S 1331 \&$ 1441(b) (1970).

${ }^{41}$ See note 10 supra \& accompanying text.

42 Some commentators have suggested that Congress confine challenges to state enactments to state fora. See, e.g., Wechsler, supra note 29 , at 229 . One reason that course may have once seemed unsatisfactory lacks validity today. Earlier in the century it was often impossible to challenge state enactments in state court without violating them, and irreparable damage often resulted from the violation that was necessary in order to test the law. See, e.g., Ex parte Young, 209 U.S. 123, 131, 144-48 (1908). Now, however, the vast majority of states have adopted the federally enacted declaratory judgment procedure.

${ }^{43}$ Johnson Act, 28 U.S.C. § 1342 (1970); Tax Injunction Act, 28 U.S.C. \$ 1341 (1970).

${ }^{44}$ Such a procedure appears to be the one advocated by Chief Justice Burger in his dissent in Wisconsin $v$. Constantineau, 400 U.S. at 440 , though there is some indication that the Chief Justice would require abstention only in cases considered "non-urgent." See id. at 443 . But cf. id. at 442 n.2.

${ }^{45}$ Chief Justice Burger appeared to recognize a conflict between this approach, which he advocated in Constantineau, see note 44 supra, and the congressional juris- 
Congress' grant of original federal question jurisdiction allows for federal factfinding and federal determination of legal issues on the hypotheses that federal judges are more capable of deciding questions of federal law and are more sympathetic to federal constitutional claims than are state court judges. ${ }^{46}$ Federal judges are primarily responsible for mastering federal law, while state judges concentrate on state law. And it has been argued that federal courts, trial and appellate, accord greater deference to Supreme Court pronouncements, produce a more unified system of national law, and are more independent of local pressures than state tribunals on issues of fact as well as of law. ${ }^{47}$ Bias against federal claims may not be widespread among state court judges, but the ease with which the judge who finds the facts can alter the ultimate result in a case ${ }^{48}$ makes such a bias particularly difficult to guard against without original federal jurisdiction. Since bias may be especially likely when state law provisions are claimed to transgress federal constitutional bounds, ${ }^{49}$ the fact that the state interest is particularly great in this group of cases can cut in favor of original federal jurisdiction rather than cutting in favor of original state jurisdiction. Nor would the possibility of Supreme Court review as the sole federal input in these cases adequately protect the federal interests embodied in the jurisdictional statute. That tribunal has a limited capacity which is already overtaxed.50 It is by no means certain that it could or would hear every case in which it would ultimately determine the federal claim to be a deserving one. ${ }^{51}$ More-

dictional arrangement when he called that arrangement "unwise" and "unwarranted." 400 U.S. at 443 (Burger, C.J., dissenting). The quoted adjectives were directed toward the use of three-judge courts and direct Supreme Court review of their decisions, rather than to the existence of federal jurisdiction as such, and the Chief Justice's comments in general seem influenced by a distaste for the threejudge court procedure, which is applicable to many Pullman challenges. See 28 U.S.C. $\$ 2281$ (1970). If the procedure is unwise, Congress should remedy its shortcomings rather than the judiciary using abstention to sidestep it.

${ }^{46}$ Mishkin, The Federal "Question" in the District Courts, 53 Colum. L. REv. 157, 158-59 (1953) [hereinafter cited as Mishkin].

${ }^{47}$ Id. $158-59,175$.

${ }^{48}$ See, e.g., England v. Louisiana State Bd. of Medical Examiners, 375 U.S. 411 , 416-17 (1964); Townsend v. Sain, 372 U.S. 293, 312 (1963); Prentis v. Atlantic Coast Line Co., 211 U.S. 210, 228 (1908); Osborn v. Bank of the United States, 22 U.S. (9 Wheat.) 738, 822 (1824).

${ }^{49}$ See ALI STUDY, supra note 33, at 282.

so Burger, Report on the Federal Judicial Branch, 94 S.Ct. 3, 11-12 (1973).

${ }^{51}$ See C.A. WRIGHT, supra note 8, at 494. Though appeals of right inhere in the defeat in state court of constitutional challenges to state statutes, 28 U.S.C. $\S$ 
over, when the Court does grant a full hearing it typically will not review the factual determinations that state courts have made, ${ }^{52}$ even though such determinations dictate the resolution of the federal constitutional claims.

\section{Allowing State Courts to Decide State Issues-A Proper Purpose in Some Instances}

\section{A. The Advantages of Abstaining for State Court Decision of State Issues and Its Costs}

The Court has consistently used the abstention doctrine as a means of allowing state courts to resolve state law issues in particular types of cases. ${ }^{53}$ This use of the Pullman doctrine, in combination with the England procedure, would appear an - effective solution to some central problems of federalism. In a system in which federal courts are the final authority on questions of federal law and state courts are final on questions of state law, ${ }^{54}$ but where the two legal systems are often intertwined in a particular case, ${ }^{55}$ prior allocation to the state or federal forum would logically (except where there is some competing interest at stake $)^{56}$ be made according to the prob-

1257(2) (1970), the same is not true of challenges to other state action. Moreover, the Court disposes of many appeals on the basis of the jurisdictional statement, without a full hearing. While those dispositions are technically on the merits, they seem as similar to discretionary certiorari dispositions as to adjudication on the merits after full briefs and oral argument. See A. Bicked, The Least Dangerous BRANCH 126 (1962); address of Chief Justice Warren, ALI Annual Meeting, May 19, 1954 (quoted in Weiner, The Supreme Court's New Rules, 68 HARv. L. REv. 20, 51 (1954). But see Gunther, The Subtle Vices of the "Passive Virtues"-A Comment on Principle and Expediency in Judicial Review, 64 CoLum. L. Rev. 1, 11 (1964).

${ }^{52}$ See, e.g., Watts v. Indiana, 338 U.S. 49, 50-51 (1949) (citing Norris v. Alabama, 294 U.S. 587, 589-90 (1935)). This is not to intimate that the Court has no power to review such factual determinations, but simply to suggest that as a practical matter it is rarely exercised. For a discussion of the Court's power in that regard see Mishkin, supra note 46, at 173-74.

${ }^{53}$ See, e.g., Lake Carriers' Ass'n v. MacMullan, 406 U.S. 498, 510-12 (1972); Zwickler v. Koota, 389 U.S. 241, 249 (1967); Harman v. Forssenius, 380 U.S. 528, 534-35 (1965); Davis v. Mann, 377 U.S. 678, 690-91 (1964); England v. Louisiana State Bd. of Medical Examiners, 375 U.S. 411,416 n.7 (1964); Harrison v. NAACP, 360 U.S. 167, 176-78 (1959).

${ }^{54}$ Murdock v. City of Memphis, 87 U.S. (20 Wall.) 590, 618-33 (1875).

${ }^{55}$ See H. HaRT \& $\mathrm{H}$. WeChSLER, supra note 8 , at 470-71.

${ }^{56}$ The most obvious example is diversity jurisdiction. See 28 U.S.C. $\S 1332$ (1970). Its purpose is often deemed to be protecting out-of-staters from state court discrimination, actual or feared. See Guaranty Trust Co. v. York, 326 U.S. 99, 111 (1945); Erie R.R. v. Tompkins, 304 U.S. 64, 74 (1938); Bank of United States v. 
ability that a particular forum's law will be the more important to the disposition of the controversy. ${ }^{57}$ The probability obviously is not always fulfilled. If state courts are left with a case that turns, either entirely or in part, upon a federal question, state courts are under a duty, imposed by the supremacy clause, to decide the case in accordance with Supreme Court decisions. ${ }^{58}$ Similarly, if a case within the federal jurisdiction requires resolution of a question of state law, federal judges are under a duty to decide that question as they believe the highest court of the state would decide it. ${ }^{59}$

Despite its limitations, ${ }^{60}$ the availability of Supreme Court review does afford some protection against error or bias when state courts decide federal issues. When federal courts decide questions of state law, however, there is no possibility of any review within the authoritative state judicial system of their prediction of how state tribunals would rule. The abstention doctrine, by contrast, allows a case to be divided so that federal tribunals can make the final decision on the federal issues and the facts on which they are based, while state tribunals have the final decision on state issues, thereby apparently providing a means of securing the most correct possible decision on every issue. If it were costless, one would wonder why that approach would not be embraced in every case involving both state and federal issues.

The advantages of abstention, however, are obtained only at a high price. Parties who have chosen to litigate in federal court are shuttled into state court for prior determination of a state law issue, involving them in considerable delay and expense. ${ }^{61}$ The England case, for example, was decided on

Deveaux, 9 U.S. (5 Cranch) 61, 87 (1809). Cf. Friendly, The Historic Basis of Diversity Jurisdiction, 41 HARv. L. REv. 483, 495-97, 510 (1928).

${ }^{57}$ Mishkin, supra note 46, at 164-65. See Iowa-Des Moines Bank v. Bennett, 284 U.S. 239 (1931); Ward v. Love County, 253 U.S. 17 (1920); Hart, The Relations Between State and Federal Law, 54 Colum. L. REv. 489, 507 \& n.56 (1954); Comment The State Courts and the Federal Common Law, 27 Albany L. Rev. 73 (1963).

${ }^{58}$ See Free v. Bland, 369 U.S. 663 (1962); Local 174 v. Lucas Flour Co., 369 U.S. 95, 102-104 (1962).

59 Erie R.R. v. Tompkins, 304 U.S. 64, 78 (1938). See Hart, supra note 57, at 510; Kurland, Mr. Justice Frankfurter, the Supreme Court and the Erie Doctrine in Diversity Cases, 67 YALE L.J. 187, $204-218$ (1957). See also C.A. WRIGHT, supra note 8 at 236-41.

${ }^{60}$ See notes 50-52 supra \& accompanying text.

${ }^{61}$ E.g., Harrison v. NAACP, 360 U.S. 167, 180 (1959) (Douglas, J., dissenting); see Clay v. Sun Ins. Office, 363 U.S. 207, 228 (1960) (Douglas, J., dissenting). 
the merits only after nine years of litigation; final decision came five years after abstention was ordered. ${ }^{62}$ The decision in Spector Motor Service, Inc. 0. O'Connor, which followed the procedure England later endorsed, was rendered nine years after the action began and seven years after abstention was ordered. $^{63}$ And an order of abstention may cause a case never to reach final decision; the added delay may moot the controversy, ${ }^{64}$ or the plaintiff out of frustration may abandon the suit. ${ }^{65}$

The burden that abstention places on the litigants raises the question whether transferring jurisdiction from federal to state court is consistent with federal jurisdictional statutes. Abstention for state decision of state law issues is less troublesome in this regard than abstention for state decision of federal questions. A traditional justification for Pullman abstention is that even if federal courts should not decline congressionally accorded jurisdiction, ${ }^{66}$ this kind of abstention "does not ...

${ }^{62}$ England v. Louisiana State Bd. of Medical Examiners, 375 U.S. 411 (1964). Suit was brought in 1957. Id. at 413 \& n.1. Abstention was ordered in 1960. 180 F. Supp. 121 (E.D. La. 1960). Final decision came in 1965. 246 F. Supp. 993 (E.D. La. 1965).

' ${ }^{63}$ Suit was apparently brought in 1942. See Spector Motor Service, Inc. v. McLaughlin, 47 F. Supp. 671, 673 (D. Conn. 1942). Abstention was ordered in 1944. 323 U.S. 101 (1944). Final decision came in 1951. 340 U.S. 602 (1951).

${ }^{64} \mathrm{See}$ United States v. Leiter Minerals, Inc., 381 U.S. 413 (1965), which was dismissed as moot 11 years after the litigation commenced and 8 years after abstention was ordered. See Leiter Minerals, Inc. v. U.S., 352 U.S. 220 (1957); Leiter Minerals Inc. v. U.S., 329 F. 2d 85 (5th Cir. 1964).

${ }^{65} \mathrm{See}$ Government \& Civic Employees Organizing Comm'n, CIO v. Windsor, 353 U.S. 364 (1957), remanding a case to state court a second time, after which the plaintiff abandoned suit, having failed to obtain a decision on the merits after four years of litigation, including one trip to the Alabama Supreme Court and two to the United States Supreme Court. Abstention was ordered in 1953. 116 F. Supp. 354 (N.D. Ala. 1953). See 353 U.S. at 365-66.

${ }_{66}$ See Cohens v. Virginia, 19 U.S. (6 Wheat.) 264, 404 (1821) (Marshall, C.J.). See also Willcox v. Consolidated Gas Co., 212 U.S. 19, $39-40$ (1909). In Pullman Justice Frankfurter found authority for abstaining in the equitable discretion of the chancellor and in the policy of avoiding "needless friction with state policies." 312 U.S. at 500 . Yet there is no statutory basis for declining jurisdiction in this situation out of a "regard for public consequences," as there is under the Tax Injunction Act and the Johnson Act. 28 U.S.C. $\$ \S 1341-42$ (1970). Moreover, at the time of the Pullman decision, the federal question statute provided that federal courts should have jurisdiction over "all civil actions, at law and in equity, wherein the matter in controversy exceeds the sum or value of $\$ 3,000$, exclusive of interest and costs, and arises under the Constitution, laws, or treaties of the United States," with no indication that in equity cases the courts were free in their discretion to refuse to exercise the jurisdiction thus granted. Act of March 3, 1911, ch. 231, § 24, par. 1, 36 Stat. 1091, as amended, 28 U.S.C. $\$ 1331$ (a) (1970). And in another context Justice Frankfurter has denied that courts' equitable discretion allows them to remand to the states 
involve the abdication of federal jurisdiction, but only the postponement of its exercise." 67 Under the England procedures, federal questions can eventually be resolved by federal tribunals. ${ }^{68}$ The postponement that abstention entails and its requirement that the parties undergo two trials may, however, effectively deter litigants from exercising their right to federal jurisdiction. ${ }^{69}$ One possible rationale for the rules the federal courts have formulated delimiting pendent jurisdiction oyer state claims ${ }^{70}$ is that the right to choose a federal forum should not be burdened by the necessity of either abandoning related state law claims or vindicating them in a separate lawsuit. The practical effect of abstention seems inconsistent with that rationale.

Nevertheless the courts have deemed it within their power to "restrain their authority because of 'scrupulous regard for the rightful independence of the state governments' and for the smooth working of the federal judiciary". ${ }^{71}$ Even if one can accept federal court power to abstain for state court decision of state issues, there remains the difficulty of deciding how the competing interests should be reconciled. In view of the costs of abstention, it should be strictly limited to situations

cases Congress has placed within federal jurisdiction. Alabama Public Serv. Comm'n. v. Southern Ry., 341 U.S. 341, 355 (1951) (Frankfurter, J., concurring in result). But see id. at 345-51; Burford v. Sun Oil Co., 319 U.S. 315, 317-18 (1943); Great Lakes Dredge \& Dock Co. v. Huffman, 319 U.S. 293, 297-98 (1943); Pennsylvania v. Williams, 294 U.S. 176, 185 (1935).

${ }_{67}$ Harrison v. NAACP, 360 U.S. 167, 177 (1959), quoted with approval in England v. Louisiana State Bd. of Medical Examiners, 375 U.S. 411, 416 (1964).

${ }^{68}$ The assumption is that federal decision of the federal issues in a case is a sufficient exercise of jurisdiction. The federal question statute is not explicit in conferring jurisdiction to decide state issues, though the Supreme Court has consistently so interpreted the federal question power. See UMW v. Gibbs, 383 U.S. 715 (1966); Osborn v. Bank of the United States, 22 U.S. (9 Wheat.) 738 (1824). And federal courts' renunciation of decision of state issues theoretically should not affect the substance of the -ultimate decision since they are bound to follow state courts' reading of state law. Abstaining can therefore be viewed as a means for allowing federal courts better to decide cases rather than as a renunciation of their power to decide.

${ }^{69}$ There are two-levels on which the deterrent effect may operate. The possibility of being remanded to state court may cause the litigants at the outset to forego their right to a federal forum. Or litigants remanded to state court may decide to present all of their claims, state and federal, to that court rather than undergo the additional delay and expense of a subsequent hearing on the federal issues.

70 Pendent jurisdiction exists if "considered without regard to their federal or state character, a plaintiff's claims are such that he would ordinarily be expected to try them all in one judicial proceeding. ..." UMW v. Gibbs, 383 U.S. 715, 725 (1966).

${ }^{71}$ Railroad Comm'n. v. Pullman Co., 312 U.S. 496, 501 (1941) (citing DiGiovani v. Camden Fire Ins. Ass'n. 296 U.S. 64, 73 (1935)). 
in which real harms are likely to result from federal exercise of jurisdiction and in which deferring to state adjudication is likely to avert those harms. The Supreme Court has made clear that state courts should not be given an opportunity to rule on state issues in every case, ${ }^{72}$ or even in all cases involving challenges to state enactments they have never construed. ${ }^{73}$ The standards the Supreme Court has adopted for limiting the situations in which Pullman abstention can be ordered are that state law must be unclear and that it must be subject to an interpretation that will avoid the federal constitutional question. ${ }^{74}$ There is little judicial analysis, however, of how unclear state law must be, ${ }^{75}$ though without resolving that question we know little indeed about the scope of abstention. ${ }^{76}$ If a state

${ }^{72}$ See, e.g., Reetz v. Bozanich, 397 U.S. 82, 86 (1970); Zwickler v. Koota, 389 U.S. 241, 248 (1967); Harman v. Forssenius, 380 U.S. 528, 534-35 (1965); Propper v. Clark, 337 U.S. 472 , 492 (1949).

${ }^{73}$ See note 78 infra.

${ }^{74}$ See, e.g., Lake Carriers' Ass'n v. MacMullan, 406 U.S. 498, 510 (1972); Reetz v. Bozanich, 397 U.S. 82,86 (1970); Harman v. Forssenius, 380 U.S. 528, 534-35 (1965). Though cases applying the Pullman doctrine consistently enunciate these requirements, the Chief Justice's dissent in Wisconsin v. Constantineau, 400 U.S. 433 (1971), indicated that he and Justice Blackmun may wish to depart from current standards for abstention, not only in allowing it so that state courts can pass first on federal issues, see note 35 supra \& accompanying text, but also by not requiring ambiguity in state law; the Chief Justice referred with approval to the abstention in Reetz v. Bozanich, 397 U.S. 82 (1970), although he thought that the state provisions there "could not have been more plain, or less susceptible of a limiting construction." 400 U.S. at 442.

In addition to the requirement of an unclear state law on which a federal constitutional issue depends, there must be available an adequate state remedy for obtaining a resolution of the state law issue. See Railroad Comm'n v. Pullman Co., 312 U.S. 496, 501 (1941). That requirement is discussed infra, text accompanying notes 199-204. For other possible requirements, see text accompanying notes 155-66, 177-98 infra.

${ }^{75}$ Similarly there is little analysis of how great the likelihood of avoiding the federal constitutional question must be. The likelihood of avoiding the constitutional issue in these cases will, however, turn on the clarity of state law; there is more likelihood in Pullman cases of avoiding the constitutional question if a state issue is very ambiguous than if the state issue is less ambiguous.

${ }^{76}$ The indications of the necessary probabilities in the cases range from the totally uninformative formulations of the recent decision in Lake Carriers' Ass'n v. MacMullan, 406 U.S. 498 (1972), ordering abstention because the unconstrued state provisions at issue were "susceptible of 'a construction ... that would avoid or modify the .. . constitutional question," "id. at 510 , and because the Court was "satisfied that authoritative resolution of the ambiguities in the [state] law is sufficiently likely to avoid or significantly modify the federal questions . . . to warrant abstention,' id. at 512 (emphasis added); to the statement in Harman v. Forssenius. 380 U.S. 528, 534-35 (1965), that "[i]f the state statute in question, although never interpreted by a state tribunal, is not fairly subject to an interpretation which will render unnecessary or substantially modify the federal constitutional question, it is the duty of the fed- 
issue were considered "unclear" whenever there was any possibility that the state judiciary might resolve the issue in a way other than that which appeared most likely to the federal court, that requirement could allow abstention almost automatically in cases containing a federal constitutional claim that is dependent upon the resolution of state law. ${ }^{77} \mathrm{Or}$, at the opposite extreme, the requirement could limit abstention to cases in which the state law issue is utterly ambiguous. ${ }^{78}$ To

eral court to exercise its properly invoked jurisdiction" (emphasis added); to the statement in Reetz v. Bozanich, 397 U.S. $82,86-87$ (1970), that the federal court should abstain because "a state court decision here . . . could conceivably" avoid the necessity for the federal courts to decide the federal constitutional issues (emphasis added).

${ }^{77}$ The verbal formulations of the abstention prerequisites that the Court uses would, in fact, most often indicate that the amount of state law unclarity needed is slight indeed. In Fornaris v. Ridge Tool Co., 400 U.S. 41, 44 (1970), the Court ordered abstention because it was "conceivable" that the Puerto Rican statute "might be judicially confined to a more narrow ambit which would avoid all constitutional questions" (emphasis added); and in Harrison v. NAACP, 360 U.S. 167, 177 (1959), the Court abstained because it was "unable to agree that the terms of these three statutes leave no reasonable room for a construction by the [state] courts which might avoid in whole or in part the necessity for federal constitutional adjudication, or at least materially change the nature of the problem" (emphasis added). See also cases quoted in note 76 supra. Since there is almost always a possibility that a state court in a Pullmantype case might construe state law to affect or avoid the federal constitutional issue, the above language could be deemed to impose a rule of exhaustion of state remedies on state law issues.

For stricter formulations of the degree of unclarity required, see Chicago v. Atchison, T. \& S.F. Ry., 357 U.S. 77, 84 (1958); Burford v. Sun Oil Co., 319 U.S. 315 , 339 (1943) (Frankfurter, J., dissenting).

${ }^{78}$ Favoring such a reading are statements that abstention is proper "only in narrowly limited 'special circumstances,'" Zwickler v. Koota, 389 U.S. 24I, 248 (1967), cited with approval in Reetz v. Bozanich, 397 U.S. 82, 86 (1970), and the many Supreme Court cases not ordering abstention despite the presence of state law issues that the state judiciary could resolve, see, e.g., Harman v. Forssenius, 380 U.S. 528 (1965); Davis v. Mann, 377 U.S. 678, 690 (1964).

The abstention doctrine could also be applied so that enactments that the state courts have never construed are deemed necessarily "unclear." Such a rule could explain cases like Reetz v. Bozanich, 397 U.S. 82 (1970), and Harrison v. NAACP, 360 U.S. 167, 178 (1959), in which unconstrued enactments seemed relatively unambiguous. See Wisconsin v. Constantineau, 400 U.S. 433, 442 (1971) (Burger, C.J., dissenting) (discussing the clarity of the state provisions in Reetz). See also Lake Carriers' Ass'n v. MacMullan, 406 U.S. 498, 512 (1972). Other cases, however, make clear that there is no special rule for unconstrued enactments. In Harman v. Forssenius, 380 U.S. 528, 534-35 (1965), the Court said, "The [Pullman] doctrine . . contemplates that deference to state court adjudication only be made where the issue of state law is uncertain. If the state statute in question, although never interpreted by a state tribunal, is not fairly subject to an interpretation which will render unnecessary or substantially modify the federal constitutional question, it is the duty of the federal court to exercise its properly invoked jurisdiction." (Emphasis added). See also Chicago v. Atchison, T. \& S.F. Ry., 357 U.S. 77 (1958); Doud v. Hodge, 350 U.S. 485, 487 (1956); Toomer v. Witsell, 334 U.S. 385 (1948). In any event, it would appear 
be functionally justifiable, the prerequisites to abstention should reflect a special need for state court input on the state issues involved. Properly applied, the requirements the Court has adopted can, in large part, ${ }^{79}$ accord with that rationale.

\section{B. The Proper Application of Existing Requirements That}

State Law Be Unclear and Be Susceptible to an Interpretation

That Will Avoid a Federal Constitutional Question

1. The Importance of a Significant Lack of

Clarity in the State Law Issue

The Pullman doctrine is impelled by a fear that federal court decision of some state law issues risks improvident interference with a valid state program or unnecessary decision of a federal constitutional question, or both. It is important to notice that such risks can arise only when the federal court would err in deciding a state issue in the sense that the highest state court would contradict its holding. ${ }^{80}$ Consequently, a federal court should abstain only when the chance of error is reasonably great. Even then, it should order abstention only if that course significantly reduces the likelihood of error occurring.

It is usually the case that the federal judiciary is capable of determining state law with accuracy. If there are precedents, the court can read and construe them. If there are none, but there are analogous decisions, it may be able to determine

more in keeping with the Pullman standard to differentiate between issues according to whether they have passed through the state judicial system than to differentiate between enactments that state courts have or have not construed, since a state court may have considered an enactment without reaching the specific issue facing a federal court.

${ }^{79}$ The exception is treated in my proposal to abandon the requirement of a federal constitutional issue in certain cases. See text accompanying notes 169-76 infra.

${ }^{80}$ In fact, not even every case in which the federal court makes such an error will result in one of these two consequences. In a case, like Pullman, in which the state law contention is that a particular provision is not authorized, one abstention policy-avoiding unnecessary constitutional decisionmaking-is transgressed if the federal court holds the provision authorized when the state courts would disagree. And if the federal court mistakenly holds that state law does not authorize the provision in question in a case in which, if the federal court did reach the constitutional issue, it would hold the provision constitutionally valid, it violates the other abstention policy by unjustifiably interfering with a legitimate state program. If, however, in the latter instance the federal court would in any event hold the state program violative of the Federal Constitution, the result it reaches, though the grounds are erroneous, is the proper one, and the federal mistake has not caused the court to transgress either policy behind the abstention doctrine. 
from them the way a state court is likely to rule. ${ }^{81}$ Even if there is no case law to guide the court, the wording of an unconstrued statute may be sufficiently clear on the point at issue. ${ }^{82}$

Of course, there is always a possibility that the federal court will err in deciding the state law issue. Even if the issue is referred to the state court system, however, there is a possibility of error. The tone of abstention discussions seems frequently to reflect an assumption that if a state issue is remanded to the state courts, their disposition will necessarily be the correct one. ${ }^{83}$ This attitude is supported by the fact that the "correct" disposition in this context means the one that the state judiciary would make. The standard, however, refers to the highest court of the state. ${ }^{84}$ And many lower state court decisions will not be reviewed by the state's highest court. Since that tribunal alone has "the last word" 85 on state law, such decisions will be tentative in much the same way that federal determinations are. ${ }^{86}$ If in Pullman, for example, the lower

${ }^{81}$ Cf. Mason y. American Emery Wheel Works, 241 F.2d 906 (1st Cir. 1957) (state court indicated its intent in dictum).

${ }^{82}$ See Harman v. Forssenius, 380 U.S. 528, 534-35 (1965). But see Harrison v. NAACP, 360 U.S. 167, 178 (1959).

${ }^{83}$ See, e.g., Louisiana Power \& Light Co. v. City of Thibodaux, 360 U.S. 25, 30 (1959); Spector Motor Service, Inc. v. McLaughlin, 323 U.S. 101, 105 (1944); Meredith v. Winter Haven, 320 U.S. 228, 236 (1943) (dictum); Chicago v. Fieldcrest Dairies, 316 U.S. 168,172 (1942).

${ }^{84}$ See Vandenbark v. Owens-lllinois Co., 311 U.S. 538, 543 (1941); West v. American Tel. \& Tel. Co., 311 U.S. 223 (1940); 1A Moore, Federal Practice 10.309 , at 3327 \& n.5 (1965); cf. Bernhardt v. Polygraphic Co. of America, 350 U.S. 198, 211 (1956) (Frankfurter, J., concurring); Union Bank \& Trust Co. v. First Nat'l Bank, 362 F.2d 311 (5th Cir. 1966).

${ }^{85}$ Railroad Comm'n v. Pullman Co., 312 U.S. 496, 499 (1941).

${ }^{86}$ Even apart from the possibility of review by the highest state tribunal, state courts are arguably more likely than federal courts to decide state law. in accordance with what the highest tribunal would rule. Federal judges may be less adept with state precedent and practice than are members of the state judiciary, since a lesser part of their work concerns state law and a greater familiarity with federal law is expected of them than of state court judges. $C f$. text accompanying note 46 supra. In some state systems an offsetting factor may be that the holders of positions on the highest state court are more like federal judges in background and training than they are like lower state court judges. Cf. Mishkin, supra note 46, at 158-59. Moreover, most federal district judges are drawn from the local bar of the area in which they usually sit, a factor noted by Justice Frankfurter in Pullman. 312 U.S. at 499. See also Propper v. Clark, 337 U.S. 472, 486-87, 489 (1949); Clay v. Sun Ins. Office, 363 U.S. 207, $227-$ 28 (1960) (Douglas, J., dissenting). This factor is also responsible for frequent deference in federal appellate decisions to the experience of the district judge on local matters. See, e.g., Bernhardt v. Polygraphic Co. of America, 350 U.S. 198, 204 (1956); Huddleston v. Dwyer, 322 U.S. 232, 237 (1944); MacGregor v. State Mut. Life Assur. Co., 315 U.S. 280, 281 (1942). Nevertheless abstention was ordered in Pullman and in Reetz v. Bozanich, 397 U.S. 82 (1970), where two members of the three-judge panel 
Texas courts held the Commission's order authorized and the highest state court did not review the decision, but several years later in another case held the order unauthorized, its determination would control, and the federal court in Pullman would have had needlessly to decide the federal constitutional question. ${ }^{87}$

Even if a remand to state tribunals does increase the likelihood of correct disposition of state issues, there is no sharp dichotomy between the state and federal systems in this regard; both systems face the possibility of error, and both are capable of arriving at "correct" decisions in most cases. One might conclude that the increment in the likelihood of arriving at a correct conclusion by abstaining is simply not great enough to justify abstention's costs. That conclusion would be correct, I submit, if the abstention doctrine were applied indiscriminately to obtain the state courts' state law solutions in all cases in which state enactments were attacked as violative of the Federal Constitution. One can, however, narrow the pool of cases for abstention in such a way that the difference in likelihood of correct adjudication between state and federal judicial systems increases.

Limiting abstention to cases in which the state law issue is extremely unclear accomplishes that result. The more unclear the state issue is, the more likely federal error would appear to be. Of course, the same ambiguity would contribute to a likelihood of error on the part of the lower courts in the state judicial system. And theoretically the relevant criterion for abstention should not be the intrinsic likelihood of federal error but the likelihood of federal error in relation to the likelihood of state error. The chances of state error are related in large part, however, to the chances of review by the highest state court, which normally will be incalculable at the time the federal court is deciding whether to abstain. The authoritative state tribunal may be more likely to exercise its discretion to review "important" cases, if they can be selected out, than others. But the decisions that the lower state courts render will also be influential; when an important state program is

which decided the case under state law "feeling sure of its grounds on the merits" were former Alaska lawyers. Id. at 86.

${ }^{87}$ Indeed, there may be some uncertainty whether a ruling is definitive even when the highest state court does speak, especially if the court is closely divided or if the area of law is a rapidly evolving one. 
held invalid, the chances of review are probably greater than when it is upheld.

When the likelihood of review by the highest state tribunal is not calculable, the federal court should decide whether to abstain on the assumption that the likelihood of state review is constant, and should base its decision solely on the likelihood of federal error in the particular case. This approach is justifiable because the factors that maximize the chances of federal and lower state court error-that the state law is unclear and has never been construed by the highest state tribunal, for example-probably do not decrease the chances of full state review. Consequently, it is justifiable to assume that the ambiguity of state law increases not only the intrinsic likelihood of federal error but also the degree to which the state judicial system is more likely to reach a correct result than are the federal courts. The greater the ambiguity, the greater is the difference in the capacities of the state and federal systems to reach the "correct" result, and the more warranted is abstention.

Even if abstention is limited to instances in which state law is extremely unclear, the question must be faced whether increasing the chances of obtaining the correct state law result is worth abstention's costs. The answer is a function not only of the likelihood of federal error but also of the seriousness of its two possible consequences-interference with a legitimate state program and unnecessary federal constitutional adjudication.

\section{An Analysis of the Reasons for Abstaining for State Court Decision of Unclear State Issues}

\section{a. Avoiding Interference With a Legitimate State Program}

It may be argued that when state enactments are challenged as federally unconstitutional, federal error in deciding a state law issue cannot lead to serious interference with a state program. If a federal court holds that state law does not authorize the state statute or order under attack, or if it construes a state enactment differently than the highest state court would, state officials who believe that the federal court's state law decision is erroneous can usually ${ }^{88}$ correct the federal 
holding by obtaining a state ruling on the question in dispute. ${ }^{\mathbf{8 9}}$ Despite principles of res judicata, a federal court will reopen the controversy and modify the decree in accordance with the state court's decision. ${ }^{90}$ Such a procedure bears a marked

will harm the state most conspicuously, for the federal courts will have not only the preliminary but also the permanent decision on questions of state law.

${ }^{89}$ If the issue is the validity of a particular statute or order on its face, as it was in Pullman, but the federal court has enjoined its enforcement only against the party who brought the action challenging it in federal court, the state attorney general can obtain a state ruling on the issue by bringing an enforcement proceeding against another party in state court. It is not settled whether a federal judge should confine an injunction to the named plaintiff-whether an individual or a class-or should derive the scope of an injunction from the substantive issues in a case and allow it to apply to parties other than plaintiffs. Compare Martin v. Creasy, 360 U.S. 219, 223 n.4 (1959) with Potts v. Flax, 313 F.2d 284, 288-90 (5th Cir. 1963). See generally O. Fiss, Injunctions 484-509 (1972). If a federal judge follows the latter approach and issues an injunction against enforcement of the statute generally, the attorney general would seem to risk contempt of court by bringing an enforcement proceeding. He should, however, be able to proceed under a state declaratory judgment procedure, naming as defendant any person against whom he wishes to enforce the statute.

The most problematic situation arises when the disputed federal ruling applies peculiarly to the plaintiffs in the federal suit. If, for example, the federal holding is not that the statute is generally void but instead that it should be construed as inapplicable to the particular plaintiffs, there may be no similarly situated person against whom the attorney general can bring a proceeding to test the issue. In that situation the federal court, in order to avoid assuming for itself the final authority to decide the state law issue, should permit the attorney general to name as deferidant, in a state declaratory judgment proceeding, the successful plaintiff in the federal suit. Such a procedure does force a party to face two lawsuits because he has chosen to litigate in federal court; therefore it should be permitted only when no other means of obtaining a state forum are available to the attorney general. In that situation, however, the burden on the litigant may be justifiable. He is less prejudiced than when abstention is ordered: Though he must bear the cost of a subsequent state proceeding, he does not suffer the delay involved in abstention, for he obtains a federal ruling pending the state determination of its law.

Similar reasoning might support allowing an enforcement proceeding against the same party involved in the federal action in those few states lacking a declaratory judgment procedure or a procedure for issuing advisory opinions, in situations in which no other means of obtaining a state ruling exists. But such a procedure should not be allowed, since it would fully deprive the party of the benefits of his federal court victory. It seems preferable to require states to provide a declaratory judgment procedure as the price of correcting federal errors on state issues in cases in which there is no appropriate defendant other than the person who was plaintiff in the federal suit. $C f$. text accompanying notes 143, 202-04 infra.

${ }^{90}$ When a federal court rests its decision on a state question and thereby avoids a federal constitutional question, the decree will often include a provision expressly authorizing reopening in the event that the question of state law is subsequently decided differently in the state court. See Lee v. Bickell, 292 U.S. 415 (1934); Wald Transfer \& Storage Co. v. Smith, 290 U.S. 602 (1933); Glenn v. Field Packing Co., 290 U.S. 177 (1933). Even if the federal judge neglects to insert such a provision, the decree can be modified when the state court has authoritatively spoken. It is this possibility of modification that led Justice Frankfurter to fear in Pullman that a federal ruling on the state issue would be "tentative." See 312 U.S. at 500. 
resemblance to abstention. There are two law suits, possibly between the same parties, and each forum speaks with final authority on its own law. It may involve as much delay as abstention before the controversy is ultimately resolved, but nonetheless it should be preferable to the claimants. Under such a procedure, the federal court will rule on the validity of the challenged state enactment before any state court ruling, and any relief may issue immediately, to be disturbed only after a corrective state judgment. Under the abstention procedure, relief cannot issue until the state court has ruled. ${ }^{91}$

For precisely that reason, however, a refusal to abstain can be much more harmful to state interests than is abstention, even though the state can ultimately correct an erroneous federal ruling on state law. Depending upon the speed of the state judicial system, it may take several years to correct an erroneous federal interference with a state program. The delay will be exacerbated if the federal court is unwilling to modify its decree until the state's highest court has passed upon the issue. ${ }^{92}$ During this period the state will lose the benefit of the program it enacted, and, depending on the nature of the program, the damage to state interests may not be compensable if the program is ultimately ruled valid. ${ }^{93}$ Indeed, the state program may be such that the postponement involved effectively defeats the interests that the program was designed to protect. A program limiting fishing rights with the purpose of preventing a particular species from becoming extinct, for

${ }^{91}$ Another reason the claimants should prefer this procedure is that in many circumstances they will not have to be party to the lawsuit that the state commences. See note 89 supra.

${ }_{92}$ The Court's disposition in Fornaris v. Ridge Tool Co., 400 U.S. 41 (1970), suggests that federal courts may so act. Lower Puerto Rican courts had spoken on the state law question at issue but the United States Supreme Court ordered abstention because the Supreme Court of Puerto Rico had not authoritatively construed the statute.

${ }^{93}$ See generally Lockwood, Maw \& Rosenberry, The Use of the Federal Injunction in Constitutional Litigation, 43 Harv. L. REv. 426 (1929). A procedure whereby the federal court at the outset of the case grants interlocutory relief to a party it feels will ultimately prevail on the merits can have the same effect. As in abstention cases and those involving erroneous federal decision of state issues, the potential harm is the damage that is done to the claimants or to the state pending ultimate resolution of the issue. If the interlocutory relief is issued in favor of the party who ultimately prevails, no harm is done. But if the interlocutory relief is later held to have been erroneous, state programs might already have suffered irreparably. See generally Hutcheson, A Case for Three Judges, 47 HARv. L. Rev. 795, 803-05 (1934); Note, The Three-Judge District Court: Scope and Procedure Under Section 2281, 77 Harv. L. REv. 299 (1963). 
example, may have its object defeated by a few years' delay. A lake may become polluted beyond the possibility of a recreational use while the federal court postpones enforcement of a state's anti-pollution program designed to preserve the lake for recreational purposes.

The interference with state programs that an erroneous federal decision can cause therefore usually takes the form of delaying the state program, not ultimately forbidding it. A court should take special care to avoid such interference when dealing with a program that is of some importance to the state and that serves purposes which are especially vulnerable to delay. Conversely, if the program is of minimal importance or if the delay an erroneous decision would cause would be compensable after the fact, the interests in making certain that the federal court does not erroneously void it sharply decrease.

\section{b. Avoiding Unnecessary Decision of Federal Constitutional Issues}

If the only consequence feared from failure to abstain were improper interference with state programs, abstention would seem unnecessary in cases in which state law appeared to validate the challenged state action. Indeed, a federal court could abstain in fewer cases still by simply presuming in favor of the state on the state law issue and proceeding directly to the federal constitutional question. ${ }^{94}$ In cases in which the federal constitutional issue was dispositive-where the state action presumed valid under. state law would be federally unconstitutional-the issue of abstention would not need to be reached, and the parties would enjoy immediate relief. In cases in which the federal court held it was not dispositive, the court could then decide whether it should abstain or should itself rule on the state law issue. ${ }^{95}$

Neither approach has been utilized because either would

94 The suggested approach would reduce significantly the occasions for abstention although it could operate in far fewer cases in which the meaning of the challenged state enactment is at issue than it could in those in which the state issue is whether state law authorizes the challenged state action. See text accompanying notes 129-31 infra.

95 Continued presumption in favor of the state on the stadte issue in lieu of abstention would seem undesirable. It would deprive the private litigants of the usual rules of pendent jurisdiction, allowing them to have their state as well as federal claims decided in federal court, and would thereby deter some from invoking federal jurisdiction. 
transgress the other policy that underlies the abstention doctrine-that of avoiding unnecessary decision of federal constitutional questions. That long-standing federal policy ${ }^{96}$ affects the disposition of Pullman abstention cases in two ways. First, it prevents a federal court from presuming initially in favor of the state in order to avoid a possibility of erroneous interference with a state program and instead encourages it first to decide the state law question. Second, the policy encourages a federal court that would decide the state issue in such a way that the federal constitutional issue would remain to abstain in order to ensure the correctness of its view of state law; ${ }^{\mathbf{9 7}}$ if abstention would alter its state law ruling, the constitutional question might not have to be reached.

The policy of avoiding unnecessary constitutional decisions is not, however, absolute; while "usually" pursued, a court can depart from it for "important reasons." 98 It might therefore be argued that the policy does not sanction Pullman abstention at all on the ground that the burden that abstention places on the parties constitutes an "important reason" for not applying the rule of avoidance. But even if one believes that it sometimes can be more important to avoid the constitutional issue than to respect the parties' interests, it should be recognized that the balance does not always favor avoidance and that it is more important to avoid unnecessary pronouncements concerning some constitutional issues than others. Some of the Court's language in Pullman suggests the propriety of abstaining to avoid only "sensitive" constitutional issues, ${ }^{99}$ but

${ }^{96}$ See Ashwander v. Tennessee Valley Authority, 297 U.S. 288, 346-47 (1936) (Brandeis, J., concurring). The purpose of avoiding unnecessary constitutional adjudication, while less self-evident than the purpose of not striking down valid state enactments, derives from the doctrine of Marbury $v$. Madison and the essentially antidemocratic nature of judicial review. See generally A. Bickel, supra note 51, at 111-33. In its classic form at least, the policy of avoiding constitutional decisionmaking speaks only to the desirability of avoiding that basis for decision when other grounds for decision exist; it does not support avoiding decision of the case itself. See Gunther, supra note 51, at I6-17, \& 22. But see A. BICKEL, supra at 69-72, 127-33, \& 174.

${ }^{97}$ The first effect of the policy, but not the second effect, has little operation when the state law issue is the challenged enactment's meaning instead of its validity. See text accompanying notes $129-31$ infra.

${ }^{98}$ Siler v. Louisville \& N.R.R., 213 U.S. 175, 193 (1909). But see A. BICKEL, supra note 51 at $127-33$.

${ }^{99}$ Although the case involved several constitutional challenges, Justice Frankfurter's explanation of why the district court should not have acted referred to the need for avoiding only one issue, that involving racial discrimination, which Frank- 
other decisions have not articulated any such limitation. ${ }^{100}$ It is difficult, of course, to ascertain with any confidence which constitutional issues are "sensitive," but one can imagine factors that might be relevant: ${ }^{101}$ the question might be sufficiently novel that the court is uncertain of the answer it would give; the issue might have particularly far-reaching consequences, not all of which the court is satisfied it foresees; the decision might be one that congressional action will soon make unnecessary; or the court might not be satisifed that the particular controversy presents the issues in a realistic light. Conversely, if a constitutional issue is a particulary easy one that does not involve any of the above factors, the interests in avoiding its decision may be sufficiently minimal to warrant relief to the parties from the delay and expense that abstention entails.

Although the Supreme Court did not articulate this reasoning in its recent decision in Wisconsin $v$. Constantineau, ${ }^{102}$ that case might be explained in terms of the absence of reason to avoid the particular constitutional issue involved. The case concerned the constitutionality of a Wisconsin statute that provided for a one-year prohibition of the sale or gift of intoxicating liquor to any person who by "excessive drinking" had exposed himself or his family "to want," injured his health, endangered the safety or property of another, or become "dangerous to the peace of any community." 103 The local chief of police applied the statute to Ms. Constantineau by posting a notice in all retail liquor stores in her community forbidding all persons to sell or give her liquor for one year. The statute contained no provision for notice or hearing prior to the posting, and Ms. Constantineau had not in fact been given those procedural protections. ${ }^{104}$ A three-judge court enjoined enforcement of the statute on the ground that it violates federal due process so to expose an individual to "public embarrassment and ridicule" without giving him "notice of the intent

furter said "touches a sensitive area of social policy upon which the federal courts ought not to enter unless no alternative to its adjudication is open." 312 U.S. at 498 .

${ }^{100}$ See, e.g., Zwickler v. Koota, 389 U.S. 241, 249 (1967); Harrison v. NAACP, 360 U.S: 167, 177 (1959); Chicago v. Fieldcrest Dairies, 316 U.S. 168, 173 (1942).

${ }^{101}$ For a thorough discussion of possible factors, see A. BICKEL, supra note 51, at $345-48$.

102400 U.S. 433 (1971).

${ }^{103}$ See WIS. STAT. $\$ 176.26 \& 176.28$ (1967) (repealed 1971).

104400 U.S. at 435 . 
to post and an opportunity to present his side of the matter."105

The Supreme Court affirmed, ruling that the Wisconsin statute was unambiguous in its failure to provide for notice and hearing, and that "abstention should not be ordered merely to await an attempt to vindicate the claim in a state court."106 It did not address the dissenting assertion of the Chief Justice that a provision of the Wisconsin constitution might be sufficient to dispose of the case. ${ }^{107}$ Instead, it ruled on the dispositive federal constitutional issue without invoking the policy in favor of avoiding such issues, which would have encouraged it first either to decide the state issue itself or to refer it to state courts by abstaining.

The opinions did not discuss whether the state constitutional provision invoked by the Chief Justice was sufficiently clear, or the case law respecting it sufficiently developed, that the federal court could itself have applied it; or whether, instead, the state issue would have required abstention. ${ }^{108}$ When

${ }^{105}$ Constantineau v. Grager, 302 F. Supp. 861,864 (E.D. Wis. 1969).
${ }^{108} 400$ U.S. at 439 .

107400 U.S. at $440-43$. There was another abstention issue as well in the case, which is discussed infra at text accompanying notes 128-43.

${ }^{108}$ The majority simply ignored the state constitutional provision. The Chief Justice did not have to address whether abstention would be proper on the basis of the classic Pullman requirements because it was his view that the state courts should necessarily have the first opportunity to pass on state law. See note 107 supra \& accompanying text.

It would not in any event have been proper to abstain for state court decision of the state issue the Chief Justice found in Constantineau because of the reason the Chief Justice gave for believing the Wisconsin constitution would invalidate the challenged enactment. This ground for abstention was not mentioned by the parties but was raised by the Chief Justice on his own initiative because he discovered a state constitutional provision that had "been held by the Wisconsin Supreme Court to be substantially equivalent to the limitation on state action contained in the Due Process and Equal Protection Clauses of the Fourteenth Amendment." 400 U.S. at 440 n.l. If the Chief Justice was correct in believing that the Wisconsin courts would invalidate the challenged enactment under their constitution because it was the equivalent of federal constitutional guarantees, that fact should not support abstention. As a general rule, a federal court should not abstain to let state courts determine whether a challenged enactment is authorized under state law when the state law provision that is claimed to invalidate the enactment is identic with a federal counterpart. An identic state law provision in this context may or may not be identical in its wording to the federal counterpart. Its important characteristic is that state courts interpreting it are motivated primarily by a desire that it conform to the federal counterpart. $C f$. Minnesata v. National Tea Co., 309 U.S. 551 (1940).

It may be difficult for a federal court to determine when a state provision is in fact identic in this sense. When it appears probable that it is, however, the federal court should not abstain so that the challenged state enactment can be invalidated under the state provision, since by hypothesis the federal court will be more adept at arriving at the correct result than a state court would be. Moreover, when the 
state law is truly clear and when ruling on it would dispose of the case, it would seem appropriate for the federal court to rule on the state issue even if the federal constitutional question also is clear and nonsensitive. But if the state issue is not so clear that federal courts deciding it can be confident of their result, or if it is less clear than the federal constitutional issue, or if the state law ruling the federal court would make would not be dispositive, then a federal court is justified in proceeding directly to a decision of the federal constitutional issue if that issue is nonsensitive, clear, and dispositive. ${ }^{109}$ In that situation, the interests in favor of avoiding the federal constitutional issue are minimal; they do not warrant either making the parties suffer the costs of abstention or taking a risk that the federal court through a state law ruling will erroneously interfere with a state program.

The Court apparently considered the dispositive federal constitutional issue in Constantineau a clear and nonsensitive one. ${ }^{110}$ On that hypothesis, as long as the state issue was not more clear than the federal one, the Court's failure to consider the state constitutional provision was justified. ${ }^{111}$ But the great-

state enactment in question is a constitutional provision that the federal court deems identic to a federal constitutional provision, the court should decide the federal question before the state question, since an initial decision on the state issue is necessarily a decision on the federal issue, and thus will not avoid federal constitutional decisionmaking.

It is true that the Wisconsin Supreme Court had termed the state provision the Chief Justice invoked only "substantially," but not precisely, equivalent to the due process and equal protection clauses of the fourteenth amendment. 400 U.S. at 440 n.1 (Burger, C.J., dissenting). But that does not support abstention because the only reason the Chief Justice gave for believing the state provision might be relevant at all was that holding on the part of the Wisconsin court; there was nothing to indicate that any nonidentic aspect of the state provision might invalidate the challenged ordinance. Moreover, one might argue that federal application of a "substantially equivalent" state provision raises no greater risk of federal error than the application of any state enactment which is substantially unambiguous.

${ }^{109}$ The proper treatment of cases involving federal constitutional issues that are clear and nonsensitive but not dispositive is discussed infra at text accompanying notes 121-24.

110 Every member of the Court agreed that notice and hearing must be provided in the circumstances involved, and no Justice appeared to regard that federal decision as groundbreaking or as one that there was any special need to avoid.

11 The clarity of a dispositive federal constitutional question could, however, support an argument in favor of abstention, for it may increase the likelihood that state tribunals, if given an opportunity to pass on state issues, will dispose of them in a manner that will avoid the constitutional infirmity; if abstention had been ordered in Constantineau, the very clarity of the federal constitutional issue would increase the likelihood that Wisconsin courts would prohibit the challenged procedure under their law, thereby making decision of the federal issue ultimately unnecessary 
er the sensitivity of a federal constitutional question, the more important it is first to decide a state issue that might be dispositive, and the more justifiable it is to abstain to ensure the accuracy of an uncertain reading of state law that leaves the federal issue to be decided. ${ }^{112}$

\section{The Operation of These Policies in "Authorization Cases"}

Since each of the foregoing reasons for abstention is operative only in some situations, a court should ascertain whether the reasons can operate before it abstains in a particular case. Otherwise the parties may needlessly be subjected to the delay and expense of a second lawsuit. There are differences in the ways the abstention policies operate between cases in which the state issue is whether state law authorizes the challenged state enactment and those in which the state issue is, instead, the meaning of the challenged state enactment. I will refer

to the case. Even so, that fact should not encourage abstention. Abstaining out of confidence of thereby avoiding a federal constitutional decision when the reason for that confidence is that the outcome of the federal decision is clear to all is hardly a wise allocation of the resources of either the parties or the courts, at least when no affirmative reason appears for avoiding the particular federal constitutional decision. In a situation like Constantineau in which the outcome of the case was certain, it would seem unreasonable to require the institution of a second lawsuit when the most that abstention could accomplish is that the challenged enactment would be stricken under state law instead of under settled federal doctrine. $C f$. text accompanying notes 135-39 infra. But cf. text accompanying notes 140-43 infra.

${ }^{112}$ Arguably, a federal court should abstain in cases involving extremely sensitive constitutional questions, even if it is relatively certain that the question will have to be reached. It is always possible that the state court will dispose of the case on state law grounds, or that the case will be mooted or settled before it returns to federal court; and even if the federal question must ultimately be reached, the postponement of sensitive adjudication can serve the same delaying function as avoiding it altogether in a particular case.

The argument that it would be proper to abstain to postpone federal constitutional adjudication though it appears ultimately unavoidable in the particular case is distinct from the two reasons for abstaining discussed in the text and states a third rationale which departs from the premise that abstention is a device to guard against federal error on state law issues; that reason would apply though the federal court views state law just as the highest court of the state would. But abstaining for the purpose of delaying adjudication of the particular case seems unfair and improper. If delay is the purpose, a federal court could effect it with less cost to the parties merely by postponing its decision. The inappropriateness of the abstention device is made apparent, moreover, by the arbitrariness of delaying because of sensitive constitutional issues only in those cases which happen to embrace as well issues of state law. If delay in constitutional decisionmaking is ever by itself a valid judicial objective, see Wechsler, Toward Neutral Principles of Constitutional Law, 73 HARv. L. REv. 1, 7-8 (1959), it should be limited in cases containing state issues, as in other cases, to doctrines such as standing, ripeness, and political question," which isolate particular deficiencies in the constitutional questions at issue or in the pleadings of the parties. See generally A. BickeL, supra note 51, 111-98. 
to the first category as "authorization cases" and to the latter as "construction cases" and will discuss separately the operation of the abstention policies in each category. ${ }^{113}$

\section{a. The Importance of Identifying the Policy That Abstention Will Serve in the Particular Case}

In cases in which the state issue is the validity of a challenged enactment, an order of abstention will serve only one of the two policies behind the abstention doctrine. When a state statute is challenged as invalid under both the state and federal constitutions, for example, ${ }^{114}$ and the federal court considers the state issue unclear, the policy that abstaining furthers necessarily depends upon the nature of the state law error the federal court seeks to avoid. If, in the absence of abstention, the federal court would hold that state law authorizes the statute, it would reach the issue of the statute's constitutionality under federal law, and if its state law holding were erroneous, the federal constitutional decision would be unnecessary. Whenever a federal court abstains, instead of itself upholding the state law validity of a challenged enactment, it therefore does so in service of the policy to avoid unnecessary federal constitutional adjudication. But if the federal court, in the absence of abstention, would rule that the enactment were not authorized, abstention serves instead

${ }^{113}$ Of course a case can contain issues concerning both the state law validity of a challenged enactment and its meaning. And a case can contain several authorization issues or several construction issues. But each authorization or construction issue should be analyzed separately to see whether a federal court is warranted in abstaining for state court decision of that issue.

${ }^{114}$ It need not be a state statute that is challenged for a case to be an authorization case; the same analysis applies when any state enactment is challenged on grounds that some provision of state law-whether or not it is the state constitution -renders it invalid. Moreover, this Article takes the position that the analysis of attacks on state action other than enactments should be similar. See text accompanying notes 146-51 infra. Pullman is an authorization case; the state issue was whether the Commission's order was within its statutory powers; the issue was not the meaning of the enactment being attacked but rather the meaning of the provision claimed to invalidate it. See notes 14-23 supra \& accompanying text. And the issue the Chief Justice raised in Constantineau, see notes 107-08 supra \& accompanying text, was an authorization issue, though the case contained a construction issue as well, see text accompanying notes 128-29 infra. The Chief Justice's authorization issue should not in any event warrant abstention, however, because the state constitutional provision that might possibly have invalidated the challenged statute was deemed to derive its content from federal constitutional provisions. See note 108 supra. 
to avoid erroneous interference with a state program. ${ }^{115}$ In this situation, the court would not reach the federal constitutional question even if it were in error; but if in error, it would invalidate the statute though it is in fact valid under state law, and the state program might suffer without justification.

In any given authorization case, then, a judge who knows how he would rule on the state law issue can identify which of the policies behind abstention he would serve if he abstained. Such a determination can prevent pointless abstention. For example, a case may arise in which it is crucial not to interrupt the state program erroneously, ${ }^{116}$ but only minimally important to avoid a pronouncement on the federal constitutional issue at stake. If the federal judge would hold that the state law program were authorized, so that the interest abstention served would be avoidance of the constitutional issue, abstention would not seem worth its costs; but if the federal court would hold the program unauthorized, abstention might be justifiable to avoid erroneous interruption of the state program. ${ }^{117}$

The advantages of first determining what policy abstention would serve in a particular case are thus evident. But difficulties arguably exist in a rule requiring the federal courts to determine before abstaining which way they would rule on questionable state law issues. The propriety of such a requirement will be discussed shortly, ${ }^{118}$ but the extent of the difficulties it imposes can be better evaluated after analyzing precisely how the factors thus far articulated would interact if the federal court did prejudge each abstention decision in the functional manner suggested.

115 This in fact was the only policy abstention could serve in Pullman itself, for the district court had held that the Commission lacked power to issue the challenged order and the Supreme Court, pointing out that the district court included "an able and experienced circuit judge of the circuit which includes Texas and . . . two capable district judges trained in Texas law," said that if there were "no choice in the matter but to decide what is the law of the state, [the Court] should hesitate long before rejecting their forecast of Texas law." 312 U.S. at 499.

${ }^{116}$ See examples given, text accompanying note 93 supra.

117 Conversely, a case might involve sensitive constitutional issues concerning a state program that interruption would not irreparably harm; if so, there would be more justification for abstention if the federal court would otherwise hold the statute authorized.

${ }^{118}$ See text accompanying notes 125-27 infra. 
b. Cases in Which Abstention Serves to Avoid Disrupting a

Legitimate State Program

If the federal court would otherwise hold that state law does not authorize a challenged state program, abstention should not be ordered unless the state program could be expected to suffer irreparable harm from delay. That rule does not furnish precise guidance for the decision of most cases, however, for delay will often involve at least some degree of irreparable harm, and the amount of damage caused by an erroneous interruption of a state program will vary with the facts of each case. Moreover, the amount of threatened harm that is required for abstention should vary with the degree of ambiguity of the state issue and, thus, with the likelihood that a federal court deciding the issue would err. A federal court might not be willing to run even a fairly slight risk of erroneously holding that state law does not authorize a program if the error would seriously frustrate important state policy; it might abstain in that situation even though the state law were clear enough not to warrant abstention if the consequences of error were slighter.

Conversely, if the amount of harm from error is not tremendous, but is of some consequence, and the chances of error are very great, a court might justly abstain. It may abstain even though it would not do so in a case in which the same amount of harm could be caused by an erroneous ruling but the chance of error were slighter. It should be noted, however, that if a federal judge is in good faith attempting to decide state issues as he believes the highest state court would, then the chances of error as the federal judge perceives them cannot exceed fifty percent. If the federal judge sees the state law as absolutely ambiguous, so that it is wholly unclear to him whether the state judiciary would hold the challenged enactment authorized or not, he runs a fifty-fifty chance of deciding the question correctly. If state law is not wholly ambiguous, so the federal judge sees some indication that the highest state court would agree with his holding, the chances of error decrease. Since the chances of federal error cannot exceed fifty percent, and since even when federal error is most likely it is also possible that the state system will erroneously dispose of the state issue, ${ }^{119}$ the potential error must threaten 
significant harm to the state program for abstention to warrant its costs.

\section{c. Cases in Which Abstention Serves to Avoid Unnecessary Federal Constitutional Adjudication}

Similarly when, absent abstention, the federal court would hold the challenged enactment authorized, so that the interest abstention serves is avoiding federal constitutional adjudication, a significantly sensitive federal constitutional question should be requisite to abstention, and the more sensitive the constitutional question to be avoided, the more likely abstention is to remain warranted as the uncertainty of the state issue-and thus the chance of federal error-decreases. Even when the federal question is extremely sensitive, however, there may be reason not to abstain when it is fairly clear that state law authorizes the challenged state provision. Of course, as state law becomes increasingly clear in whatever direction, abstaining becomes increasingly purposeless, for the likelihood of federal error decreases; a significant lack of clarity is thus a general prerequisite to abstention. ${ }^{120}$ But slightly less ambiguity arguably is required when an enactment appears to be unauthorized than when it appears to be authorized, even if the policies underlying abstention-avoiding erroneous interference with a state program in one case and avoiding unnecessary constitutional adjudication in the other-are implicated to an equal extent. One reason is the greater likelihood of obtaining a definitive state answer to the state law question when indications are that the challenged enactment is unauthorized and that lower state courts would strike down the program; overturning a state program probably maximizes the likelihood of a definitive answer from the authoritative state tribunal. A less speculative and more fundamental reason is that the costs of abstention may be less when state law suggests that the enactment is unauthorized: If the federal court is correct that abstention will result in the state court definitively disposing of the case on the state issue-and the clearer the state law is, the more likely it is that the court is correct-no return to the federal court will be necessary because the federal constitutional issue will not have to be reached. If the federal court believes

${ }^{120}$ The one possible exception to this principle is discussed at text accompanying notes 135-39 infra. That exception, however, is qualified by the principle discussed at text accompanying notes 140-43 infra. 
correctly that the enactment is authorized, however, the case will return to the federal court in precisely the same posture as when it was sent to the state court, and the federal court will have to decide the federal constitutional issue. Abstention will have fulfilled none of its objectives.

This analysis suggests simply a slight difference in the degree of state law ambiguity requisite to abstention between the situation in which an enactment appears authorized and that in which it appears unauthorized. Alternatively, if the degree of ambiguity is constant in the two situations, it suggests a slight difference in the degree to which the relevant policy must call for abstention: The federal court should abstain slightly less readily in authorization cases involving the avoidance of constitutional questions than in those involving the avoidance of harm to state programs.

\section{d. Cases Involving Clear and Nonsensitive Federal Constitutional Questions}

As was discussed earlier, there is no important interest in avoiding adjudication of clear and nonsensitive federal constitutional questions; accordingly if such an issue is dispositive-if the challenged enactment is clearly unconstitutional-abstention is improper. ${ }^{121}$ Even when the federal constitutional issue does not call for avoidance, however, considerations of efficient decisionmaking may cut in favor of abstention in some cases in which that federal issue is not dispositive-in some cases, that is, in which the federal court would uphold the constitutionality of the challenged enactment: When the federal court believes a case to contain a clear and nonsensitive, nondispositive federal constitutional issue, and in addition the state issue is sufficiently unclear for abstention, but in the absence of abstention the federal court would hold the challenged enactment unauthorized, the court should not first decide the federal constitutional issue. ${ }^{122}$ Since the state issue

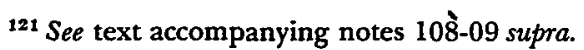

${ }^{122}$ The facts of Constantineau can be varied to provide an example in which the challenged state enactment is quite clearly constitutional (rather than clearly unconstitutional) and in which the federal court, though uncertain concerning state law, would hold it does not sanction the challenged provision. Suppose the provision relating to posting the names of "excessive drinkers" clearly does provide for notice and hearing and that the federal constitutional challenge is, instead, that it violates due process and equal protection for the state to deprive "excessive drinkers" of liquor. Let us assume as well that "excessive drinkers" is defined with sufficient pre- 
is appropriate for abstention in such a case, ruling first on the constitutional issue would require abstaining after the constitutional ruling-a course that in all likelihood would prove more costly to the litigants than abstaining on the state issue at the outset. Since, by hypothesis, the state issue is more likely to be dispositive of the controversy than is the federal issue, abstaining at the outset would settle the case more expeditiously than would having the litigants first go through the federal system on the nondispositive federal issue. ${ }^{123}$ If, however, the

cision to escape charges of unconstitutional vagueness and, further, that it seems to the federal court that the constitutional challenge, while not frivolous, is fairly clearly erroneous on the merits. The challenged posting provision is not a state statute but a city ordinance, and the state issue is whether the city may enact such an ordinance despite state legislative regulation of the distribution of liquor, which is arguably preemptive. A perusal of relevant state law leaves the federal court without confidence concerning the proper resolution of the state question. This hypothetical states a case in which, if the federal court, absent abstention, would hold the ordinance preempted, judicial efficiency would call for abstaining at the outset, before decision of the federal constitutional question.

${ }^{123}$ The soundness of this analysis is clearest if the district courts' orders of abstention will not in the normal course be appealed through the federal system. If they will be appealed, it might not significantly increase the costs of abstention for the district judge to decide the clear and nonsensitive constitutional question concurrently with the abstention issue and for the appellate courts to review the correctness of both rulings. Such a procedure would require more time at the district court level in cases in which factual findings were necessary to the constitutional ruling but not in other cases.

The appealability of orders to abstain is not definitively settled. In Idlewild Bon Voyage Liquor Corp. v. Epstein, 370 U.S. 713, 715 n.2 (1962) (per curiam), the Court held reviewable an order of abstention, but in that case the district court, contrary to the later announced England procedure, had referred the federal as well as state issues to state court. The Supreme Court's explanation of the appealability of the order-that the order was final because the "[a]ppellant was effectively out of court", id. at 715 n.2 (quoting 289 F.2d 426, 428 (2d Cir. 1961))-is not necessarily applicable in situations in which the district court, under the England procedure, retains jurisdiction. In Lake Carriers' Ass'n v. MacMullan, 406 U.S. 498 (1972), the Court, without discussing appealability, reviewed a district court decision to abstain; in that case as well, however, the district court had dismissed the complaint and had apparently referred federal along with state issues to state courts. 336 F. Supp. 248, 253-54 (E.D. Mich. 1971); see NAACP v. Bennett, 360 U.S. 471 (1959) (per curiam) (vacating, without discussion, pre-England order to abstain); County of Allegheny v. Frank Mashuda Co., 360 U.S. 185 (1959). In Louisiana Power \& Light Co. v. City of Thibodaux, 360 U.S. 25 (1959), the Supreme Court compounded the confusion by reviewing an order of abstention although it limited its grant of certiorari to exclude the question of the appealability of the order! Id. at 26 n.1. No federal issues were involved in that case, but the district court had retained jurisdiction, and the Court indicated that a state issue might return to the federal forum. Id. at 29; see notes 219-20 infra.

The American Law Institute apparently concludes from the case law that abstention orders are not reviewable, for it explains its failure to provide expressly for appellate review in its abstention proposals to Congress by saying "[s]uch review is ordinarily undesirable .... In the unusual case where appellate relief from an absten- 
federal court in the absence of abstention would hold the enactment authorized, but all other facts were the same, the court should not order abstention at the outset or at any later stage. Neither of the purposes of abstention could be served in such a case. There is no significant interest in avoiding decision of a clear and nonsensitive federal constitutional question, and the state program, since it will be upheld, cannot be harmed. ${ }^{124}$

\section{The Justification for Requiring Federal Decision of the State Law Issue Prior to the Abstention Decision}

This interplay of the abstention factors reveals that abstention will not be limited to instances in which state law is entirely ambiguous, a fact that is relevant in assessing the burden to federal courts of identifying in advance the policy abstaining would serve. In many cases in which a federal court knows which way it would rule on the state issue, the court will nevertheless consider abstaining because it is not confident that its conclusion is correct and because the harm error would entail is sufficiently great. In those situations it places no bur-

tion order is required, there should be no difficulty in working out a remedy under the All Writs Statute ...." ALI STudY, supra note 33 at 291-92. The hardship to litigants wrongfully ordered into state court militates against a conclusion that appeal is available only in extraordinary cases; instead the undesirability of review would seem to support the need for clear standards for abstention, a need met neither by current law nor by the proposals contained in this Article.

The inequities to litigants in not being able to have erroneous orders of abstention overturned may well render abstention orders "final" and appealable under 28 U.S.C. § 1291. Cf. Gillespie v. United States Steel Corp., 379 U.S. 148, 152-54 (1964); Mercantile Nat'I Bank v. Langdeau, 371 U.S. 555, 557-58 (1963); Construction Laborers v. Curry, 371 U.S. 542, 548-52 (1963); Cohen v. Beneficial Indus. Loan Corp., 337 U.S. 541, 54547 (1949); Forgay v. Conrad, 47 U.S. (6 How.) 201, 204 (1848). But cf. Catlin v. United States, 324 U.S. 229, 233 (1945); Schoenamsgruber v. Hamburg Am. Line, 294 U.S. 454, 456 (1935). Moreover, in cases in which interlocutory injunctions are requested, $c f$. Goldstein v. Cox, 396 U.S. 471 (1970), an order of abstention might be reviewable under 28 U.S.C. $\S 1292(\mathrm{a})(1)$ as a refusal of an interlocutory injunction. See Glen Oaks Util., Inc. v. City of Houston, 280 F.2d 330, 333 (5th Cir. 1960). The same reasoning could allow Supreme Court review of three-judge court decisions. See 28 U.S.C. $\S 1253$ (1970). And, of course, certification under 28 U.S.C. $\$ 1292(\mathrm{~b})$, and mandamus or prohibition under 28 U.S.C. $\S 1651$, would in any event be available in cases to which they are applicable. If abstention orders generally are considered appealable-as they would be if the finality rationale were applied despite the absence of a dismissal and despite the possibility of return to the federal court-then judicial efficiency would be served by not first deciding the federal issue in the cases discussed in the text only if the federal constitutional issue were significantly more likely to be appealed than the abstention issue, or if the constitutional issue required significant factfinding.

${ }^{124}$ When the federal constitutional issue is clear, nonsensitive and nondispositive, and the state issue is clear enough not to warrant abstention, abstention is also improper since a significant lack of clarity in the state issue is a consistent prerequisite to abstention. See text accompanying notes 80-87 supra; $c f$. note 120 supra. 
den. whatsoever on the federal court to take account of its view of the state issue in making its abstention decision.

When it is not clear to the court which way it would rule on the state issue, however, the suggested approach requires it to make that decision in order to identify which policy abstention would serve. To some extent even the current approach to abstention requires a federal court to address the merits of state issues in order to make an abstention decision, for the court is supposed to abstain only if state law is unclear. Since current decisions are uninformative concerning exactly how unclear state law must be, ${ }^{125}$ that standard may not, in practice, require the court to make an exacting determination. The absence of an ascertainable standard should not, however, be deemed a virtue; a federal judge operating conscientiously under current doctrine should first decide how unclear state law is supposed to be for abstention to be ordered and should then determine whether the state issue before it is that unclear. The extent to which that process will reflect a determination of the merits will depend upon how much ambiguity is requisite to abstention. If it were required that state law be utterly ambiguous for abstention to be ordered, the federal court would have to decide whether there were any indications concerning the outcome of the state issue before deciding whether to abstain. The federal court in effect would thereby decide how it would rule on the merits in the vast majority of the cases-that is, in all cases other than those which were utterly ambiguous.

If current standards do permit abstention only in cases of utter ambiguity, the suggested approach, then, would require an advance ruling on the merits only in a relatively small number of additional cases: those in which the state issue is utterly ambiguous. But to the extent that current standards sanction abstention when the state issue is less than altogether ambiguous, the number of cases increases in which the suggested approach requires a pre-abstention decision of the state issue that the current approach does not require. ${ }^{126}$

${ }^{125}$ See notes 76-78 supra \& accompanying text.

126 The following diagrams illustrate the point. In each the state issue is charted from clearly authorized to clearly unauthorized with utter ambiguity at the midpoint. If, as in Diagram \# 1 , the court is required to decide the issue unless it is utterly ambiguous, then in placing the case on the spectrum it effectively decides all state issues except the utterly ambiguous ones. But if, as in Diagram \#2, it can abstain when 
Even when the state issue is entirely unclear, it is not troublesome to require the federal court to identify the policy abstention would serve by determining how it would rule on the unclear state issue. The notion of requiring prior determination of an issue in order to analyze functionally the proper forum for its ultimate decision has analogues in modern conflict-of-laws analysis, which often requires a prior determination of one forum's law in order to analyze whether the law of the forum governs. ${ }^{127}$ In the abstention context the suggested procedure is justified because it enables the federal court to avoid abstention in cases in which it would not serve a valid purpose. As a general matter, then, the added burden of making the advance determination seems justified by the burdens it would avoid.

There may be individual cases, however, in which the balance of advantage differs. If the state issue is such that the federal court cannot know how it would rule without undertaking a complex factual hearing, it may sometimes be wiser to forego the advance determination and simply to abstain. Since, by hypothesis, the state issue is extremely unclear in such a case, less harm to a state program and a less sensitive federal constitutional question are necessary to justify abstention than when state law is less ambiguous. If the federal court can determine that an error would cause the requisite amount

state law is not wholly unclear, the court is not required to determine the placement on the spectrum of cases falling within the circle demarcating the area appropriate for abstention. Hence, it need not determine its ruling on the merits in that group of cases. The less ambiguity required, the fewer rulings on the merits the federal court will need to make as part of its abstention decision.

$\left\{\begin{array}{l}\text { clearly authorized } \\ \text { utterly ambiguous } \\ \text { clearly unauthorized }\end{array}\right.$

Diagram \#1

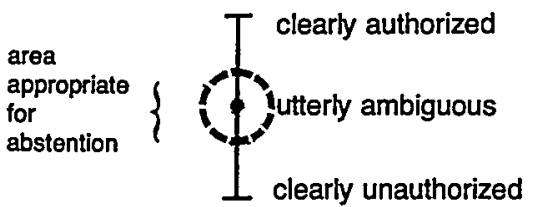

Diagram \#2

${ }^{127}$ The Restatement (Second) of the Conflict of Laws takes the position that the state with the dominant interest on each particular issue should generally have its law applied on that issue. It recognizes that "the content of the relevant local law rule of a state may be significant in determining whether this state is the state with the dominant interest. So, for example, application of a state's statute or common law rule which would absolve the defendant from liability could hardly be justified on the basis of this state's interest in the welfare of the injured plaintiff." 1 RESTATEMENT (SECOND) OF CONFLICT OF LAWS $\& 6$ at 15 (1971). 
of each of the harms then, of course, there is no need to decide the state issue before abstaining. Even if only one of the policies underlying abstention calls for abstention, however, it is conceivable that the resources expended on determining whether abstaining would serve that policy would be greater than the resources expended by abstaining. If such a case arose, abstention should be ordered although it could only serve one policy and that policy might not be at issue in the case.

\section{The Application of the Abstention Principles to "Construction Cases"}

In construction cases the state law issue is the meaning of a challenged state enactment, rather than its validity. For example, Constantineau involved an issue of construction as well as an authorization issue. While the challenged statute did not on its face provide for notice and hearing, Justice Black took the position in a dissenting opinion that "notice and hearing might be provided by principles of state administrative procedure law similar to the federal Administrative Procedure Act." ${ }^{128} \mathrm{He}$ agreed with the other members of the Court that the statute would be unconstitutional if it did not allow for notice and hearing, but he thought the Wisconsin courts should be given an opportunity to construe the statute so as to avoid both state and federal defects. The case is somewhat unusual for a construction case because the ambiguity was not evident on the face of the challenged statute but rather was found by Justice Black in other state law; that distinction, however, does not affect the abstention analysis.

Construction cases involve the same policies as authorization cases, but they operate in somewhat different ways. In construction cases it is generally not possible for the federal court to determine what constitutional issue to decide without passing upon the state law issue. Moreover, it may be much less obvious than in authorization cases which of the abstention policies abstaining in a particular case may serve. And there is a possibility in construction cases that does not exist in authorization cases: In certain cases an erroneous federal decision will not seriously threaten a state program because of the state's ability to correct it without any delay. 


\section{a. The Need to Decide the State Law Issue Prior to the Federal Issue}

Whether the ambiguity in the challenged state enactment arises from its language or from other state legislation, a federal court in the usual construction case must pass on the issue of the enactment's meaning-or abstain to have the state system do so-prior to adjudicating the federal constitutional question. This provides an important difference from authorization cases, in which it is possible for the federal court to decline to decide the state law issue and proceed to the federal one, as the majority did on the authorization issue in Constantineau. The Court did not purport to pass upon the construction issue in Constantineau any more than the authorization one; it did not mention that either point was "at issue" at all. But the opinion for the Court did say that on its face the statute did not require notice and hearing, and the Court had to pass on the construction issue, whether it recognized it as an issue or not, simply because the federal constitutional question posed was dependent upon that issue's prior resolution: If the Court had adopted the view that Wisconsin law did require notice and hearing, it would hardly have held the statute unconstitutional for failure to provide those procedural safeguards.

It is the very rare construction case in which the state issue need not be resolved first. The federal constitutional question will not require prior resolution of the state issue only if all possible meanings of the challenged state law are alleged to violate the same federal constitutional provision in precisely the same way..$^{129}$ In that situation there is no interest in a ruling on the state issue, either by the federal court or by state courts through abstention, prior to a ruling on the federal constitutional question. Much more commonly, however, the possible state law meanings will pose different federal constitutional questions, whether under the same constitutional provision or not; ${ }^{130}$ or one or more possible meanings will pose a significant

${ }^{129}$ Even if both of two possible meanings present questions under the same constitutional provision, the issues may be different: For example, if both are attacked as violative of equal protection, the equal protection argument against each meaning may differ.

${ }^{130}$ An example based on Constantineau illustrates the situation in which two possible meanings pose different constitutional problems. Suppose that the state alleged there was a Wisconsin enactment requiring notice and hearing that should be read with the posting provision, but it required notice of only five days and explicitly stated that there was no right to present witnesses at the hearing. If the posting provision were construed to mean that no notice and hearing were necessary, 
constitutional issue while the other or others do not. ${ }^{131}$ In those situations it is necessary to decide the state law issue prior to the federal one, implicitly if not explicitly, because the constitutional question will be dependent upon the resolution of the state law question.

\section{b. The Interaction of the Abstention Policies in Construction Cases}

In many construction cases it is not possible to isolate in advance one policy to be served by abstaining. If in Constantineau the construction issue is the one Justice Black describedwhether Wisconsin law provides for notice and hearing-and a constitutional issue is raised only on the theory that it does not so provide, then if the federal court would rule that notice and hearing are not provided but abstains because it is unsure of that view, abstention will serve the interest of avoiding a federal constitutional question. But such abstention may also avoid illegitimate interference with a state law program, since if the federal court's holding that state law does not require notice and hearing is erroneous, the court may possibly strike down as violative of federal due process a state enactment that properly construed is constitutional. A state court holding that notice and hearing are required, therefore, would avoid the federal constitutional issue and might, as well, prevent the state statute from being stricken down erroneously.

In some factual contexts, however, abstention in construction cases will serve only one of the abstention policies. If in Constantineau the federal court would rule that the statute does require notice and hearing, and if no constitutional issue were raised with respect to the adequacy of notice and hearing, the federal court would avoid the only constitutional question without abstaining. In that case the only policy that abstaining could serve would be avoiding unwarranted interference with the state program. If the federal court were in error in holding that state law provided for notice and hearing, and if its decision were taken to mean that the state must there-

the federal constitutionality of the failure to provide notice and hearing would be at issue. If, on the other hand, it were read in conjunction with the notice and hearing provision that the state argued for, the federal issue would be the constitutionality of the particular notice and hearing provided.

${ }^{131}$ Constantineau itself was a case in which there was a serious constitutional problem if one meaning of the statute was adopted, and no constitutional problem -at least none that was raised-if the other meaning (that notice and hearing were necessary) was chosen. 
after provide them, the federal decision might unduly and illegitimately interfere with a state program. For if the state statutory scheme in fact did not so require and if that statutory scheme were constitutionally proper-and we cannot assume it would not be proper since we have, by hypothesis, avoided deciding that federal constitutional question-then the federal court would have imposed an unwanted and unwarranted condition upon the statute's operation.

In the Constantineau example, therefore, a federal judge can learn something about which policies abstention may serve by ascertaining which way he would rule upon the state construction issue. As in authorization cases, abstention will serve no purpose unless he is wrong on his state law holding. If he would erroneously rule that notice and hearing are not required, he may serve both policies behind abstention by abstaining or he may serve only the policy against needless constitutional adjudication. If he would rule that notice and hearing are required, abstention can serve only the policy against illegitimate interference with state law programs.

The above analysis of Constantineau is typical for construction cases in which one possible construction of the state law at issue presents a constitutional problem while the other possible construction presents none. If, instead, each of the possible constructions presents a constitutional issue, then it is less likely that determining which way he would rule on the construction issue if he did not abstain will significantly advance a judge's inquiry into what policy he may serve by abstaining. Whichever way he rules he may, if in error, illegitimately limit a state program or unnecessarily decide a federal constitutional question, or both.

As in cases in which only one construction presents a constitutional issue, a state program may suffer illegitimately whichever way the federal court rules on a state construction issue, if its ruling is erroneous. The court may erroneously construe the state provision to raise a constitutional question under which it is invalid. Or it may erroneously construe the provision to avoid the constitutional issue when even if otherwise construed, it would pass constitutional scrutiny, thereby imposing upon the state program unrequired conditions. Whether the imposition has serious consequences for the program depends upon the magnitude of the federal court deviation from what the state court would hold; the importance 
of the matter on which it deviates; and the vulnerability of the program's objectives to delay.

Moreover, when each of two possible constructions raises a different constitutional issue, a federal constitutional question will be decided unnecessarily if the federal court rules erroneously in either direction. Once the federal court decides the state law issue erroneously, it will decide the wrong federal constitutional question-one that could have been avoided by correct decision of the state law issue-though it will avoid for the time being decision of the other constitutional issue, the one that is actually implicated in the case. Unnecessary decision of a federal constitutional question can still be avoided by prior correct decision of the state law issue, therefore, in the sense that any particular federal constitutional question can be avoided. ${ }^{132}$ When each of two possible constructions raises a constitutional issue, federal error on the state issue will not result in unnecessary federal constitutional adjudication only when both possible meanings are alleged to violate the same constitutional provision in precisely the same way, and that is the unusual situation in which it is unnecessary to decide the state issue prior to the federal one. ${ }^{133}$

The impossibility in many construction cases of isolating one policy that abstention may serve necessarily affects the process by which a federal judge should analyze whether to abstain. But even in cases in which either or both abstention policies may be served whichever way the federal judge rules, the judge can profit by determining before abstaining which way he would rule if he did not abstain and by deciding from that perspective whether the likelihood of abstention serving a purpose is sufficient to justify its costs. If there are two possible constitutional issues in a case, one raised by meaning $X$ of the state enactment and one raised by meaning $Y$, the one raised by $Y$ may be a sensitive issue that is important to avoid if at all possible, whereas the one raised by meaning $X$ may not be sensitive at all. In such a case it would be more important, for the purpose of avoiding federal constitutional adjudication, for a federal judge to abstain if in the absence of abstention he would rule that $Y$ were the state law meaning than if he would rule it were $X$. Of course since either ruling could also adversely

${ }^{132}$ But cf. Baggett v. Bullitt, 377 U.S. 360,378 (1964).

${ }^{133}$ See note 129 supra \& accompanying text. 
affect a state law program, the fact that the constitutional issue is not a sensitive one should not in this setting be controlling. If meaning $X$ is not sensitive because it is clearly unconstitutional but it is not at all clear whether meaning $X$ is the correct meaning, abstention might avoid invalidation of the statute. ${ }^{134}$ Or if meaning $X$ is likely to be found constitutional but that meaning may narrow the statute in an important respect that the state may not have intended, the illegitimate interference with a state program that adopting that meaning would cause might justly lead the federal court to abstain.

As in authorization cases, it may be justifiable in construction cases to abstain somewhat more readily when it appears that the case will turn ultimately on the state law issue and need not return to the federal forum than when it appears that a constitutional question will survive the state court adjudication, since in the former cases abstention is likely to be less expensive to the parties than in the latter. When each of two possible constructions is attacked as unconstitutional, however, this distinction cannot operate; in all such cases a judge should be slightly less ready to abstain. When one is attacked as unconstitutional and the other is not, a judge should be slightly more ready to abstain when he believes indications are that the state judiciary would choose the meaning that does not raise the constitutional issue than when he believes the state judiciary would rule in such a way that the constitutional issue remains. Of course, the clearer it is that the state judiciary would choose a particular meaning, the less necessary is abstention, for the federal judge need fear less that he would be in error. Moreover, if the judge considers state law utterly ambiguous, the suggested distinction should not operate, since, in cases of utter ambiguity, the ruling he would make is in no way predictive of whether the state judiciary would dispose finally of the controversy. As in authorization cases, it is only when state law is neither clear nor utterly ambiguous that a federal judge should abstain more readily when indications are that state courts will dispose finally of the controversy than when indications of equal weight suggest that a constitutional question will survive the state adjudication. 


\section{c. Abstention in Cases of Clear Federal Unconstitutionality to Allow the State to Save Its Program}

In Constantineau the suggestion that Wisconsin state courts could construe their statute to require notice and hearing was put forward by Justice Black even though the state had not argued that its statute could be so construed and even though Justice Black knew of no particular state provision that might provide the needed procedural safeguards. He thought nevertheless that, given the chance, the Wisconsin courts would correct the statute by finding the safeguards in "the body of other state law" simply because without those safeguards the statute was blatantly unconstitutional. ${ }^{135}$ Even though clear federal unconstitutionality should not support abstaining so that state courts may hold that state law does not authorize a challenged enactment, ${ }^{136}$ clear federal unconstitutionality might arguably support abstention in construction cases. For if a federal court correctly predicts that the clear unconstitutionality of one construction of the state enactment will lead the state court to adopt the other construction, abstention would appear to serve the interest of saving a statute that would otherwise be ruled in violation of the Federal Constitution.

It probably is true that when a state enactment is obviously unconstitutional if read one way and can survive if read another, a state court is likely to give it the constitutional reading. In construction cases involving a choice between two possible meanings of a state enactment, each of which seems relatively plausible, the element of clear federal unconstitutionality of one meaning probably, therefore, justifies the federal court itself deciding that the state courts would adopt the constitutional meaning, instead of abstaining for that state decision. But when the construction that quite clearly appears federally unconstitutional also quite clearly appears to be correct-either on the face of the enactment or on the basis of state law generally-difficulties inhere in federal court decision of the state issue. A state court in that situation might well choose to strain the meaning of the state enactment in order to preserve its constitutionality. ${ }^{137}$ The incentive to do

135400 U.S. at 445.

${ }^{136}$ See note 111 supra.

${ }^{137}$ For a case in which a state supreme court "performed a remarkable job of plastic surgery upon the face of the ordinance" by giving it "an extraordinarily nar- 
so will, of course, be greatest when the enactment concerns a program of importance to the state and one that would suffer much from interruption. ${ }^{138}$ It seems preferable for a federal court to abstain to allow the state judiciary to adopt a relatively implausible construction than for the federal court to render that result itself. There may well be limits on the extent to which state courts will strain the meaning of statutes to adopt a constitutional construction, and the federal court is apt to lack guidance concerning the range of those limits. It would be an illegitimate interference with state policy to require a statute to conform to constitutional requisites if state officials would prefer no statute at all. And even if a federal judge confidently believes that the state court would adopt a constitutional construction, it may be difficult to document that belief on the basis of traditional legal evidence, evidence he may feel is particularly important when he is interpreting state law to bear a meaning other than its evident one. Finally, it may be difficult to predict the manner in which the state judicial system will construe state law when a strained construction is necessary; a federal decision on a different ground than the state decision would be may have a scope quite different than the state decision it precludes. Even if a federal court confidently believes that the state judiciary will construe a challenged state enactment very freely in order to preserve it against constitutional attack, therefore, it may justifiably conclude that the state instead of the federal judiciary should reach that result. ${ }^{139}$

\section{d. The State's Ability to Correct Some Erroneous Decisions \\ Through Administrative Action}

Although a federal court may feel unable itself to adopt a strained construction even when it believes state courts would do so, in some situations it may be possible instead for it simply to adopt the apparent and unconstitutional reading of the

row construction," see Shuttlesworth v. Birmingham, 394 U.S. 147, 150, 153 (1969).

${ }^{138}$ Other factors increasing the incentive would be that the strained construction that must be adopted either (1) allows the maximum that is constitutionally permissible for the state so that it does not unnecessarily limit the state program or (2) does not deviate in any way that seems of great importance to the state from the apparent construction or at least from the closest thing to it that is constitutionally permissible.

${ }^{139}$ This reasoning may conceivably support the decision to abstain in Lake Carriers' Ass'n v. MacMullan, 406 U.S. 498 (1972). 
state enactment without causing any significant harm to state interests. Constantineau is a case in which abstention for the purpose of saving the state enactment or avoiding interference with its operation would have been inappropriate because it was "unnecessary; even if the federal court was in error in its state law ruling, the state should have been able to correct the error without delaying the enforcement of its posting statute.

It is generally the case that a state can save its statutory program when a state statute may be construed to be either constitutional or unconstitutional and a federal court erroneously adopts an unconstitutional construction. One obvious method is legislative enactment of another statute in which the construction the legislature desires is explicit, a method that is available whether the federal court's reading of the earlier statute was correct or erroneous. A second method is to take the issue of the statute's meaning to state court. Both methods, however, require the elimination of the state program pending the corrective measures; it is wrongful interference during that period that abstention is designed to prevent.

If after the federal decision in Constantineau, however, the state attorney general believed, with Justice Black, that the Supreme Court was wrong in holding that state law did not require notice and hearing, or even if he believed simply that a plausible argument could be made to that effect, he should have been able to effectuate those requirements without delay by simply informing those enforcing the statute not to invoke it without providing notice and hearing. ${ }^{140}$ In a situation like Constantineau, there is no federal-law bar to having state officials thus save the statute by operating under it without its

140 The possibility of a state through administrative action correcting an erroneous federal court ruling without delay exists only in construction cases. In authorization cases state officers cannot ever wholly remedy a federal court error on state law without judicial or legislative proceedings. Even when the federal court erroneously invalidates a state enactment because of a provision that can be removed without abandoning the entire statutory program, the federal court's error illegitimately limits the state's program. Suppose, for example, that the issue is the legality under state and federal law of a posting procedure that does not provide for notice and hearing, and that the federal court avoids the federal constitutional issue by ruling that the state constitution invalidates the procedure. If the federal court is in error in construing the state constitution to require notice and hearing, then even though state officials can save the state program by providing those safeguards, the federal court has illegitimately imposed those procedures upon the state. Only if the Federal Constitution as well requires the procedures-an issue the court has by hypothesis not decided-has the court not wrongfully limited the state program. 
constitutional defects. The injunction issued pursuant to the federal decision of unconstitutionality should not extend beyond prohibiting enforcement of the statute without notice and hearing; if it does, the order should be amendable on the motion of the proper state official. Admittedly, the Supreme Court held the statute unconstitutional and not simply the police chief's conduct, but the only reason it did so was that it deemed state law to be correctly reflected in the actions of the state officials, and state officials need not accept the federal interpretation.

Of course, erroneous construction decisions are not always correctible at an administrative level; there are instances in which it would offend a federal interest for a state to continue to enforce in any way a statute that the federal system has held unconstitutional. ${ }^{141}$ Whether a program is administratively correctible will often be a difficult issue in itself. In making that determination, a court must ask whether, on the facts of the particular program, any person may be detrimentally affected by state alteration of the federal construction at an administrative instead of a judicial level. Constantineau appears to satisfy that criterion because no federally protected interest is impinged upon by having a statute that does not reflect that notice and hearing will be provided if in fact those safeguards are provided. ${ }^{142}$

Whenever a program is administratively correctible-not simply in situations of clear federal unconstitutionality-abstention should not be ordered for the purpose of avoiding inter-

${ }^{141}$ An obvious example is a federal court holding a statute regulating speech unconstitutionally overbroad because it proscribes some activities that cannot be so regulated. See, e.g., Cramp v. Board of Public Instruction, 368 U.S. 278 (1961); Thornhill v. Alabama, 310 U.S. 88 (1940). When the overbreadth inheres in the wording of the statute, it is unlikely that state officials could constitutionally save the statute by enforcing it simply where the regulation was permissible; nor, indeed, in all probability, could the state judiciary save the statute by construing it to apply only to the nonprotected conduct. As a matter of federal constitutional law, there is an interest in not having on the books an enactment that appears to regulate first amendment activity that it is not permitted to regulate, thus "chilling" constitutionally protected conduct. Dombrowski v. Pfister, 380 U.S. 479, 486-87, 494 (1965).

142 The only argument that administrative instead of judicial correction in Constantineau might violate procedural due process is that persons aware of the Supreme Court's apparent voiding of the statute would not have notice that any posting procedure remained. Even if a state could not constitutionally have a posting procedure without embodying it in statutory form, however, the argument fails, for if persons are deemed to have notice of the Supreme Court decision they should also be deemed to have notice of the limits of the decision's effect, and one of those is its ability to be corrected at an administrative level. 
ference with the program, since an erroneous federal adjudication does not necessitate its interruption. But there is the difficulty that state officials may not feel free so to act on the interpretation of state law that the federal court has rejected. They may be unaware that federal law leaves them that option; or state law may in fact preclude correction of a federal error except through the state judiciary or legislature. State officials' ignorance can be handled by enlightenment, but state law preclusion of administrative correction presents a more difficult problem. Such state provisions causing the federal decision to have a disruptive effect might be ignored by the federal system as matters of state choice. ${ }^{143}$ When a federal court is aware, however, that as a practical matter its decision, if wrong, could seriously hamper an important state program, that reality may influence it to abstain.

6. The Application of the Abstention Policies in Cases Apparently Involving Construction in Which Conduct Under Authority of the Ambiguous Provision Is Also at Issue

The discussion of construction cases has concerned the situation in which a plaintiff challenges a state enactment under the Federal Constitution and it is not clear what that enactment means. When in addition conduct has occurred under the authority of the enactment and the plaintiff's constitutional challenge is leveled at the enactment on the theory that its meaning is consistent with such conduct, the analysis changes. Constantineau again provides an example. Assume that Justice Black was correct in believing that the body of Wisconsin law did not clarify whether the challenged statute contemplated a notice and hearing procedure or not. It was nevertheless clear that the chief of police had acted without providing notice and hearing in Ms. Constantineau's case, affecting her rights just as if his interpretation of the statute were a correct one. Because he had acted in the manner alleged to be unconstitutional, abstention was less appropriate than if no such action under the enactment had taken place. Of all the types of cases considered in this Article, the

${ }^{143}$ Since the interest protected by abstaining for this purpose is solely that of the state, it is not problematic for the state to have within its control the ability to waive that protection. See text accompanying notes 196-204 infra. 
argument for abstention is most persuasive when the meaning of the challenged enactment is ambiguous and no action taken under the enactment is challenged. In those cases, even if the plaintiff's argument as to federal unconstitutionality is a correct one, it is not certain that any unconstitutional state action has taken place. ${ }^{144}$ If in Constantineau, before the police chief had taken any action, the plaintiff had attacked the statute's constitutionality because of its apparent failure to provide procedural safeguards, there would be no unconstitutional state action, even assuming the plaintiff's constitutional contention was sound, if the plaintiff was wrong on her state law point that the statutory scheme did not provide notice and hearing. If in that situation the federal court made an erroneous state law ruling, it would render a totally hypothetical federal constitutional decision-one relating to a state law situation that simply did not exist. That cannot result in cases in which a state official has acted in accordance with the challenged meaning. In Constantineau as it actually occurred, there is no doubt that if it is unconstitutional not to provide notice and hearing, unconstitutional state action had taken place. The only unknown is whether the unconstitutional action is attributable to the state legislature or solely to the chief of police. ${ }^{145}$

An argument can be made that in the situation in which the police chief has acted a court should necessarily pass upon the constitutionality of that action instead of abstaining. In that situation, the argument runs, one or the other of two hypotheses is true, and under neither is abstention proper. If the interpretation of the enactment that the police chief acted on does in fact reflect the enactment's meaning, abstention is unnecessary because a federal court passing on the constitutionality of that interpretation by hypothesis will make no

${ }^{144}$ Many such cases may accordingly involve issues of ripeness or standing. It is not necessary, however, for a case to be justiciable, that the challenged enactment have been acted upon. Cf. Epperson v. Arkansas, 393 U.S. 97 (1968).

${ }^{145}$ The same point may be conceptualized as a difference in the ambiguity of the challenged state action in the two instances. In both the case in which the suit is brought before the police chief's action and the one in which it is brought after the action, the state enactment is ambiguous as to whether notice and hearing are required. In the latter instance, however, though the statute is ambiguous, there is state action that is the subject of attack as to which there is no ambiguity: the conduct of the chief of police, who invoked the procedure without the procedural safeguards. 
error in interpreting state law. And if instead the police chief's action does not reflect the statute's meaning, abstention is improper, according to the argument, because the constitutional attack is not levied against the enactment but simply against conduct by a state official. If Pullman abstention is improper when it is an individual state official's action that is the object of the constitutional attack, a per se rule against abstention in the category of cases under discussion would therefore follow.

The Pullman doctrine has not generally been invoked when it is an individual official's conduct that is challenged, and a case can be made that the doctrine is concerned with constitutional attacks on state enactments and not simply on unconstitutional conduct by state officials. ${ }^{146}$ But any such limitation on the doctrine would be irrational. Its rationale could not be simply that, the state official having acted, no ambiguity concerning the allegedly unconstitutional state action exists; ${ }^{\mathbf{1 4 7}}$ that rationale would distinguish such cases from construction cases in which no conduct under the challenged enactment has occurred, but it does not distinguish them from authorization cases. In authorization cases as well, the chal-

${ }^{146}$ Such a limitation does exist in the jurisdiction of three-judge courts. See 28 U.S.C. $\$ \S 2281-82$ (1970). Supreme Court cases do not discuss whether it is a limitation on Pullman abstention as well, but they almost invariably involve challenges to enactments or administrative orders and not solely individual officials' action. Some commentators refer to Pullman abstention as applicable to challenges to "state legislative or administrative action." See, e.g., ALI STUDY, supra note 33, at 282, 284; Wechsler, supra note 29, at 229. But "administrative action" may well embrace the actions of individual officials. If abstention were permissible for constitutional challenges to individual actions, it should perhaps have been considered in a case like Monroe v. Pape, 365 U.S. 167 (1961), in which the plaintiffs, who sought damages under the Federal Givil Rights Act against Chicago police officers, might have raised similar claims under the Illinois statutes and constitution. Id. at 172. Either abstaining or deciding state issues might have enabled the federal court to avoid constitutional decisionmaking if the state damage remedy was as extensive as the federal remedy and if the two were exclusive of each other. Yet without mention of the possibility, the Court proceeded to the federal issues. That the petitioners raised only federal issues is insufficient to explain why abstention was not considered, for in other contexts abstention has been considered on the Court's own motion when no claim under state law was made. See e.g., Wisconsin v. Constantineau, 400 U.S. 433 (1971) (dissenting opinions); $c f$. England v. Louisiana State Bd. of Medical Examiners, 375 U.S. 411 (1964). See text accompanying notes 196-98 infra. The fact that the suit was for damages rather than an injunction likewise does not explain the failure to consider abstaining. See Fornaris v. Ridge Tool Co., 400 U.S. 41 (1970), and text accompanying notes 177-95 infra. And no exception to the Pullman abstention doctrine exists for actions brought under the Civil Rights Act. See Harrison v. NAACP, 360 U.S. 167 (1950); notes 162-66 infra \& accompanying text.

${ }^{147}$ See note 145 supra. 
lenged state action-though it is a state enactment rather than an individual official's action-may be perfectly clear and the uncertain question of state law is whether that action is authorized. Cases attacking an individual official's conduct can thus be conceptualized as authorization cases; the state law issue is whether the official's conduct was consistent with state law or inconsistent with it.

If there is to be a difference in treatment between the cases under discussion and authorization cases that are appropriate for abstention, it must center solely on the fact that it is an individual state officer's action which is attacked as unconstitutional in one category of cases and which may or may not be consistent with state law, while in the other category of cases it is a state enactment which is attacked as unconstitutional and which may or may not be consistent with state law. It may appear plausible to maintain this differentiation for abstention purposes because one objective of the Pullman doctrine is to protect against improvident interference with ongoing state programs that reflect state legislative policy. While state statutes and administrative orders represent ongoing programs and reflect state legislative policy, an individual official's action, if not sanctioned by statute, does not rise to that level. ${ }^{148}$

But this difference would affect the way that the abstention policies operate in the two categories of cases only if it meant that, in cases challenging individual officials' actions, an ongoing state program that reflected state legislative policy could not be harmed by an erroneous federal court ruling. If that were true, it would mean that, in cases involving individual officers' conduct, the only policy that abstention could serve would be avoidance of unnecessary federal constitutional adjudication, whereas in cases involving state enactments either policy behind the abstention doctrine could be served. It is unclear why, even if that were true, abstention should be precluded, since in any particular authorization case abstention will serve only one of the policies behind the Pullman doctrine. ${ }^{149} \mathrm{But}$ in any event, it is not correct that a state legislative program cannot be adversely affected in an illegitimate way by an erroneous state law decision in a case involving a

${ }^{148}$ Cf. Phillips v. United States, 312 U.S. 246 (1941), applying the similar limitation in the three-judge court act. See note 146 supra.

${ }^{149}$ See text accompanying notes 114-18 supra \& text accompanying notes 169-76 infra. 
constitutional attack on an individual state official's action. If the federal court erroneously decides that the official's conduct is not authorized, it thereby interprets state law to be narrower than it is and binds the state by that adjudication to the same extent as in other authorization cases. ${ }^{150}$

Of course, when individual conduct is the subject of challenge, if the federal court rules that the conduct is inconsistent with state law and it is correct in that ruling, no state legislative policy will suffer; only a deviation from that policy on the part of an individual officer, or a group of individual officers, will be stricken down. Cases like Pullman in which state enactments are at issue differ. In those cases, state legislative policy will be stricken down even if the federal court is correct in its state law ruling, though by hypothesis it will be a state legislative policy that, for other reasons of state law, it was illegitimate for the enacting body to make. But this difference between cases involving state enactments and those involving individual officials should not affect the application of the abstention doctrine, since that doctrine's purposes are accomplished only in the event that the federal court is incorrect in its state law holding.

In short, abstention should be ordered in cases involving challenges to individual officials' actions on the same basis that it is ordered in authorization cases; in both these categories the case for abstention is weaker than in construction cases in which conduct has not occurred. ${ }^{151}$

150 To use the Constantineau example, a federal court that avoided the federal constitutional question and held that state law precluded the police chief from acting without notice and hearing would, if it was wrong about the meaning of state law, narrow the meaning of the state statute. Unless the state statute happened in any event to be federally unconstitutional, it would thereby illegitimately narrow the state program.

${ }_{151}$ While the hypothetical character of a federal decision makes abstention most appropriate in construction cases where conduct has not occurred, see text accompanying notes $144-45$ supra, on that ground it is roughly equally appropriate in authorization cases and in construction cases where conduct has occurred. Perhaps as a category, the last group is slightly less appropriate for abstention than authorization cases, for in construction cases in which conduct has occurred, by definition, a state official has necessarily affected the plaintiff in the same way as if his action were authorized. In authorization cases, that may or may not be the situation. On the facts of Pullman, for example, porters might or might not be already affected by the state action challenged as unconstitutional, depending upon whether it had already been put into effect.

The effect on the parties of delaying adjudication should be taken into account in an abstention decision, but more is involved than simply inquiring whether the allegedly unconstitutional action currently affects them. It should also be relevant 
7. Summary of Suggested Rules for Applying Current Requirements That State Law Be Unclear and That It Be Susceptible to an Interpretation That Would Avoid a Federal Constitutional Question

\section{a. Authorization Cases}

Before abstaining in an authorization case, the federal judge should ascertain whether abstaining will serve any purpose by determining which way he would rule on the state law issue in the absence of abstention. If he would hold the program unauthorized, so that abstention might prevent interference with a state program, he should ascertain also whether the program would suffer irreparable harm from interruption. The greater the harm, the more this factor weighs in favor of abstention; but in any event a significant degree of harm should be required. Similarly, if the judge would hold the program authorized, so that abstention might avoid unnecessary constitutional adjudication, he should determir, whether the constitutional question is one that it is especially tesirable to avoid adjudicating. The more desirable it is to avoid, the more this factor weighs in favor of abstention.

When a constitutional question is not particularly difficult or sensitive and would dispose of the case, the federal court should not abstain regardless of how unclear state law is and how it would rule on the state law issue. Instead (unless the state issue is even clearer than the federal issue and also is dispositive), it should rest its decision on the federal issue. But the rules may differ if the federal issue, though clear and not sensitive, is also not dispositive. In that case, it may be permissible to order abstention if the state issue is unclear and the federal court would hold the enactment unauthorized, ${ }^{152}$ but not if the issue is clear or if the court would hold it authorized.

how important is the respect in which it affects them and how much swift adjudication will ameliorate their situation. For those reasons and because authorization cases can involve completed state conduct, it seems desirable in deciding whether to abstain to inquire in each case whether the parties' situation is or is not one in which swift adjudication is particularly desirable to them, rather than to make abstention more readily available in authorization cases as a class than in cases involving completed conduct by individual officials. Similar reasoning supports not limiting abstention to construction cases in which conduct has not occurred. See note 173 infra.

152 The permissibility of abstention in this situation depends largely upon the appealability of abstention orders. See note 123 supra. 
The above factors usually require a federal judge to determine how he would rule in a particular case before he decides the abstention question. Even if state law is entirely ambiguous, so the judge lacks any confidence that his ruling is correct, by making the determination he can eliminate purposeless abstention. The judge can avoid prejudging the state issue if he decides that the facts of the case warrant abstention to fulfill either abstention policy. Or, in the very rare case, he may conclude that the costs of determining the state issue prior to abstaining outweigh the costs of a possibly purposeless abstention.

While the necessity of prejudging the state issue generally obtains no matter how unclear that issue is, there is another abstention factor that is relevant only when the state issue though still unclear is not wholly ambiguous: In cases involving such a state issue, the argument for abstention is somewhat stronger if the enactment appears unauthorized than if it appears 'athorized. If the indications of how state courts would ri? are strong, however, abstention is improper because the likelihood of an erroneous federal result is slight. ${ }^{153}$

${ }^{153}$ The following diagram suggests some of the factors relating to abstention decisions in authorization cases:

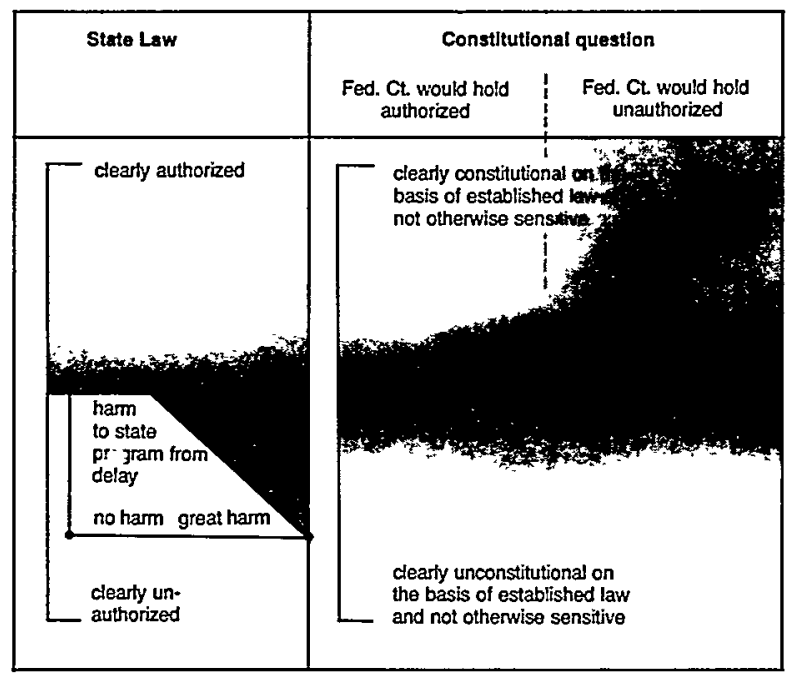

Abstention possible only when case falls in gray area on both issues. (If one issue is in the lighter area. the case for $a b$ stention is aided if the other is in the darker area. If both issues are in the fringe areas, abstention may be improper.)

Cases involving state law authorization are placed on the "state law" spectrum according to how clear the state law issue appears to the federal judge. The spectrum extends from clearly authorized to clearly unauthorized state enactments, with the 


\section{b. Construction Cases}

If there are two possible readings of the state law at issue and if both meanings are alleged to violate the same federal constitutional provision in precisely the same way, abstention is inappropriate, and regardless of the ambiguity of the state law issue, the federal court should proceed immediately to the federal constitutional question. In the usual case in which the court must first decide the state law issue, however, it should abstain only if that issue is very unclear. Even then the federal court should not abstain if two conditions both exist: first, if the state law meaning the federal court would adopt is either clearly unconstitutional or clearly constitutional on the basis of established and nonsensitive federal constitutional doctrine; second, if the state program is such that an erroneous federal court construction can be corrected without delay, or if the program will not suffer any irreparable harm from any delay caused by the error limiting or invalidating it. In that situation, though there may be error on the state law issue, it cannot significantly affect any interest that the abstention doctrine is designed to protect. It should be noted that where the federal issue is clear and not sensitive, no differentiation is made among cases according to how the constitutional issue would be decided. Construction cases are unlike authorization cases in this respect because in construction cases, whichever way the federal court rules on the federal issue, its ruling will dispose of the controversy.

Abstention should be permissible when state law is highly ambiguous and the above conditions are not present. The degree of ambiguity required may be less as the sensitivity of the federal constitutional issue increases, or as the harm to the state program that an erroneous federal construction might cause increases; but in any event substantial ambiguity is required. ${ }^{154}$

Abstention is slightly more justifiable when it appears that the state court decision will be dispositive-that it will

cases where state law is utterly ambiguous on the authorization issue falling in the middle. The federal constitutional issue-whether the challenged state enactment, authorized by state law or not, violates the Constitution-is placed on a similar spectrum according to the degree to which it appears clear and/or sensitive to the judge making the abstention decision.

${ }^{154}$ The following diagram embodies the principles thus far articulated: 
choose a state meaning to which no constitutional challenge is made-than when it does not. Finally, when a state program appears clearly unconstitutional in some respects but is a program that a strained construction of state law might save and that would be important to state interests to save, abstention may be proper to enable the state judiciary so to save the program, if the program is one that cannot be corrected at an administrative level.

c. Construction Cases in Which Conduct Under the Ambiguous Enactment Is Also at Issue.

Abstention should operate in the same manner in these cases as in authorization cases.

C. A Countervailing Factor-The Relevance of a Public Interest in Swift Adjudication of the Federal Constitutional Issue

Even when the factors suggested above would mandate abstention, the nature of the federal constitutional issue should

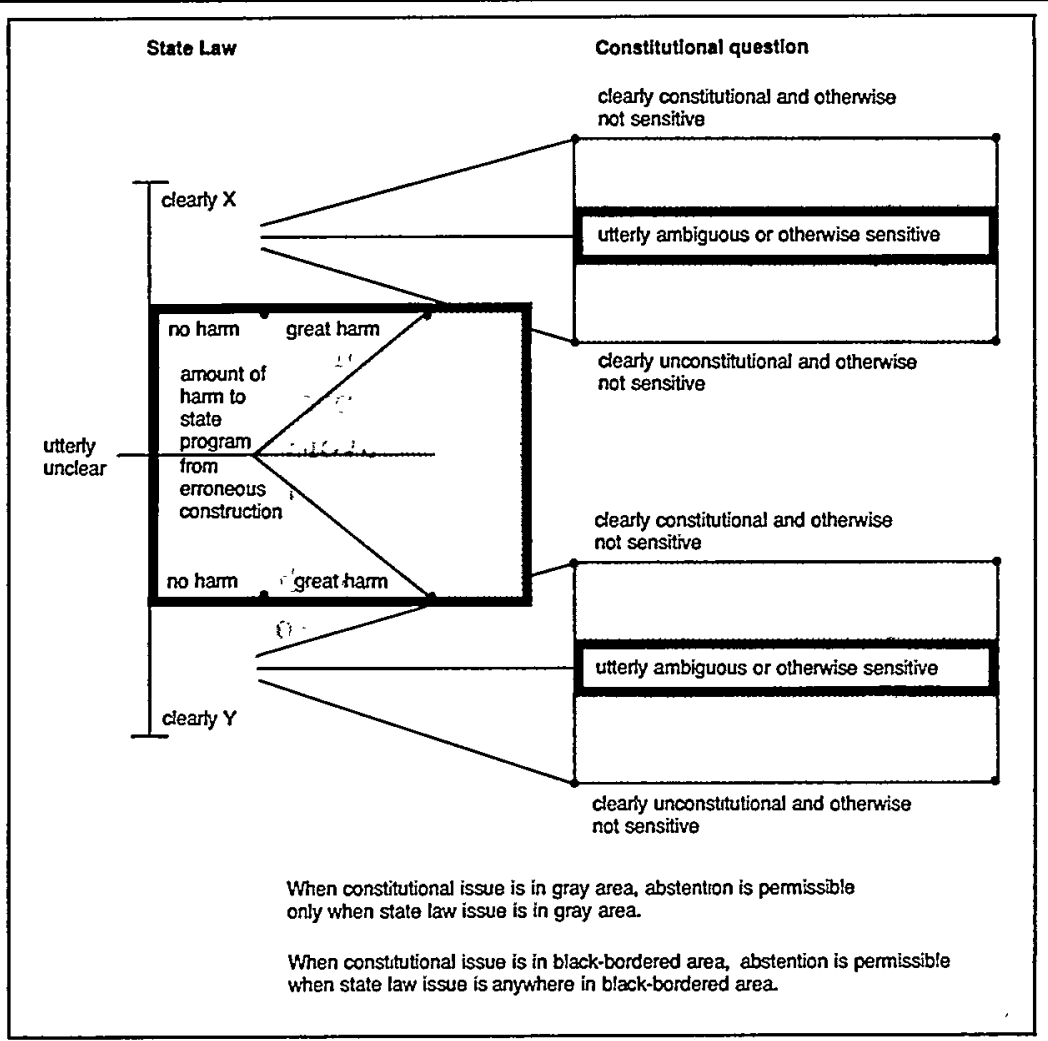


sometimes preclude it. There is some recognition in the case law on abstention that the impact of a delay in the adjudication of federal rights should be a separate factor in a decision whether to abstain. In Baggett v. Bullitt ${ }^{155}$ and Zwickler v. Koota, ${ }^{156}$ for example, the Court held abstention improper not only on the ground that the statutes there involved were not reasonably susceptible to a construction that would avoid the constitutional questions at issue, but also because "in [first amendment cases] . . . to force the plaintiff who has commenced a federal action to suffer the delay of state court proceedings might itself effect the impermissible chilling of the very constitutional right he seeks to protect." ${ }^{157}$ And Harman v. Forssenius $^{158}$ involved an attack on the constitutionality of newly promulgated state voting provisions requiring, as a condition of voting in federal elections, that a person either pay a poll tax or file a certificate of residence six months before the election. The Court said it was proper not to abstain, not only because the state statutes were clear, but also because the deprivation alleged was "fundamental," the "civil rights of a broad class of citizens" were affected, and the forthcoming election made the problem an immediate one. ${ }^{159}$

Since there were independent reasons not to abstain in all the cases suggesting the nature of the federal question as a factor in abstention decisions, it is not definitively settled that such a factor exists. In any event the factor should be recognized; harmful public consequences resulting from abstention should be weighed in the balance against the public injury that the abstention is designed to prevent. Clearly, when the interest abstention would serve is avoiding federal constitutional adjudication, a court should consider facts affirmatively calling for swift constitutional decision in deciding whether to abstain. The same should be true when the other abstention policy is at stake. Just as there may be an especially strong state need in a particular situation not to have the status quo erroneously changed, so in some situations there may be par-

155377 U.S. 360 (1964).

156389 U.S. 241 (1967).

${ }^{157} 389$ U.S. at 252. See also 377 U.S. at 379 (citing Smith v. California, 361 U.S. 147,151 (1959)).

158380 U.S. 528 (1965).

${ }^{159} \mathrm{Id}$. at 537. See also Dombrowski v. Pfister, 380 U.S. 479, 489-90, 491-92 (1965), discussed in note 166 infra. 
ticular need to change the status quo rapidly, when that is to be the ultimate and the correct disposition; in that event the federal interest in expeditious decision should be balanced against the state interest. ${ }^{160}$

The question remains which federal issues show particular need for swift adjudication. The answer depends in part upon the factual situation in each particular case just as the factor of harm to a state program does. First amendment issues and issues pertaining to racial discrimination may be the most obvious candidates for especially expeditious treatment, as Baggett, Zwickler, and Harman might indicate. Some commentators have considered the need for speedy decision of particular federal issues sufficiently great that they have recommended to Congress a per se rule precluding abstention when those issues are raised. ${ }^{161}$ And some language in McNeese v. Board of Education ${ }^{\mathbf{1 6 2}}$ could support an argument that section 1983 (civil rights) actions are a court-imposed exception to the abstention doctrine. ${ }^{163}$ That interpretation would create an enormous exception to Pullman abstention, for today virtually all constitutional challenges to action under color of state law can

${ }^{160}$ It may, of course, happen that some issues calling for swift adjudication are also "sensitive," so that the nature of the constitutional issue theoretically cuts both for and against abstention in the same case. Or possible harm to a state program that might be avoided by abstaining may cut in favor of abstention though an interest in deciding the federal constitutional question cuts against it. These observations militate against a per se rule and in favor of decisions on a case-by-case basis, in which all relevant factors can be balanced.

161 When advocating a general rule that the presence of an adequate state remedy should require a litigant to use the state rather than the federal forum, Professor Wechsler also suggested an exception for "the rights of action specially conferred by Congress in the Civil Rights Laws," because "Congress has declared the historic judgment that within this precious area, often calling for a trial by jury, there is to be no slightest risk of nullification by state process." Wechsler, supra note 29 at 230 . The American Law Institute has made an exception to its abstention proposal, discussed in note 33 supra, for "actions to redress the denial, under color of any State law, statute, ordinance, regulation, custom, or usage, of the right to vote or of the equal protection of the laws, if such denial is alleged to be on the basis of race, creed, color, or national origin," ALI STUDY, supra note $33, \S 1371(\mathrm{~g})$, at 50 , because "there is an especially strong national interest in a federal forum for such cases." Id. at 297.

162373 U.S. 668 (1963).

${ }^{163}$ In McNeese the plaintiffs, who were black, claimed they were racially segregated in the Illinois public schools, and sought to enjoin such segregation. The state provided an administrative remedy for racial segregation, which the plaintiffs had not exhausted. The Supreme Court held that the plaintiffs could come directly to federal court, bypassing both state administrative and judicial remedies. Justice Douglas said for the Court:

Where strands of local law are woven into the case that is before the federal court, we have directed a District Court to refrain temporarily from 
be brought under the Civil Rights Act. ${ }^{164}$ The language in $M c N e e s e$ seems too slight a peg on which to hang the exception, and other cases do not support a per se exception either for

exercising its jurisdiction until a suit could be brought in the state court. See Railroad Comm'n v. Pullman Co., 312 U.S. 496; Thompson v. Magnolia Co., 309 U.S. 478; Harrison v. NAACP, 360 U.S. 167. Thus we have stayed the hands of a Federal District Court when it sought to enjoin enforcement of a state administrative order enforcing state law, since any federal question could be reviewed when the case came here through the hierarchy of state courts. Burford v. Sun Oil Co., 319 U.S. 315. The variations on the theme have been numerous.

We have, however, in the present case no underlying issue of state law controlling this litigation. The right alleged is as plainly federal in origin and nature as those vindicated in Brown v. Board of Education, 347 U.S. 483 . Nor is the federal right in any way entangled in a skein of state law that must be untangled before the federal case can proceed. For petitioners assert that respondents have been and are depriving them of rights protected by the Fourteenth Amendment. It is immaterial whether respondents' conduct is legal or illegal as a matter of state law. Monroe v. Pape, supra, at 171-187. Such claims are entitled to be adjudicated in the federal courts. Monroe v. Pape, supra, at 183; Gayle v. Browder, 352 U.S. 903, affirming 142 F. Supp. 707; Borders v. Rippy, 247 F.2d 268, 271. Cf., e.g., Lane v. Wilson, 307 U.S. 268; Smith v. Allwright, 321 U.S. 649; Schnell v. Davis, 336 U.S. 933, affirming 81 F. Supp. 872; Turner v. Memphis, 369 U.S. 350.

373 U.S. at 673-74 (footnote omitted).

As Pullman analysis, the reasoning seems faulty. The Pullman requirement is more than that "strands of local law are woven into the case that is before the federal court." And McNeese does not escape being appropriate for Pullman abstention for the reason Justice Douglas gives. It is not true in the Pullman sense that there was present "no underlying issue of state law controlling [the] litigation," simply because the right the plaintiffs invoked was federal. The state issue was "controlling" in the same way as in Pullman: if it was decided in a particular fashion, it would dispose of the controversy and make decision of the federal constitutional question unnecessary.

The fact that $M c N e e s e$ did consider it "immaterial whether respondents' conduct is legal or illegal as a matter of state law" might, however, be taken to state a rule of Pullman abstention that is peculiar to civil rights cases. It might be taken to mean that in civil rights cases a federal court should never invoke Pullman abstention if the state law issue is whether the state rule complained of is authorized. Or McNeese might be taken to state the still broader rule that in any case in which there is jurisdiction under the Civil Rights Act, abstention should not be ordered, for state law is deemed not controlling and immaterial; the right to the federal forum is absolute. Under either of these approaches, abstention could have been avoided in the Pullman case itself if only the parties had invoked the Civil Rights Act as a ground of jurisdiction. (The difference between the cases-that in Pullman the plaintiffs raised state as well as federal claims while in McNeese they raised only federal claims -should not be dispositive. See text accompanying notes 196-98 infra.)

164 See Lynch v. Household Finance Corp., 405 U.S. 538 (1972). Prior to that decision it appeared that suits could be brought under 28 U.S.C. $\S 1343$, the statute conferring jurisdiction over civil rights actions, only if they involved "personal" and not "property" rights. It is unclear whether that limitation of $\S 1343(3)$ applied to $\S 1983$ as well. See Eisen v. Eastman, 421 F.2d 560, 565 n.8 (2d Cir. 1969) (Friendly, J.). 


\section{all section 1983 cases $^{165}$ or for any more delimited category}

${ }^{165}$ In Davis v. Mann, 377 U.S. 678 (1964), a suit under the Civil Rights Act questioning the apportionment of the Virginia legislature, the usual Pullman principles appear to have been applied in deciding whether to abstain. Both the district court and the Supreme Court declined abstention not because of any absolute rule for cases under the Civil Rights Act but because the statute was not ambiguous. Zwickler v. Koota, 389 U.S. 241 (1967), also under the Civil Rights Act, engaged in typical Pullman analysis, and Harrison v. NAACP, 360 U.S. 167 (1959), in which abstention was ordered, was brought under the Civil Rights Act. In Harrison, Justice Douglas, without success, espoused the position that Pullman abstention was inappropriate in civil rights actions. 360 U.S. at 180-81 (dissenting opinion). Admittedly, though, the cases are not conclusive. Only Harrison squarely contradicts the existence of a civil rights exception in Pullman cases, and Harrison was decided prior to McNeese. McNeese's reasoning could be deemed to have overturned it.

Askew v. Hargrave, 401 U.S. 476 (1971), a post-McNeese civil rights case, does support to some degree the proposition that no civil rights exception to Pullman abstention exists. The case involved a claim that Florida's system of financing public education discriminated against school children of property-poor countries, thereby violating equal protection. The district court enjoined the program, refusing to defer in favor of proceedings in state courts that had been instituted subsequent to the federal suit, and saying that under McNeese and Monroe v. Pape "[t]he fact that a state remedy is available is not a valid basis for federal court abstention." 401 U.S. at 478. In a unanimous per curiam opinion (after oral argument) the Supreme Court vacated the decision of the three-judge court and remanded the case to that court so it could exercise its discretion, governed by the usual Pullman principles, whether to abstain. It said:

The reliance upon Monroe v. Pape and McNeese was misplaced. Monroe v. Pape is not in point, for there "the state remedy, though adequate in theory, was not available in practice." 365 U.S., at 174. McNeese held that "assertion of a federal claim in a federal court [need not] await an attempt to vindicate the same claim in a state court." 373 U.S., at 672 (emphasis added). See also Wisconsin v. Constantineau, 400 U.S. 433 (1971). Our understanding from the colloquy on oral argument with counsel for the parties is that the Christian case asserts, not the "same claim," that is, the federal claim of alleged denial of the federal right of equal protection, but primarily state law claims under the Florida Constitution, which claims, if sustained, will obviate the necessity of determining the Fourteenth Amendment question. In such case, the line of decisions of which Reetz $v$. Bozanich, 397 U.S. 82 (1970), is a recent example, states the principles that should inform the exercise of the District Court's discretion as to whether to abstain.

401 U.S. at 478.

One factor that may be deemed to detract from whatever significance Askew might otherwise have is the existence of ongoing state court litigation which, though begun subsequent to the federal action, may have influenced the decision. $C f$. Scott v. Germano, 381 U.S. 407 (1965). See note 256 infra. Nevertheless, Askew's treatment of McNeese is significant in that it apparently abandons McNeese's implications of a $\S 1983$ exception to Pullman principles. Askew correctly says that McNeese's statement that a litigant need not await decision of the same claim in state court did not cover the situation in Askew. But as indicated in note 163 supra, it did not cover the situation in McNeese either, a fact that Askew does not point out. Repudiating that language repudiates the basis on which McNeese arguably creates a civil rights exception in Pullman cases. The Court in Reid v. Board of Educ., 453 F.2d 238, 242 (2d Cir. 1971), seems thus to have read Askew to show that abstention in $\S 1983$ actions is permissible. (Askew's distinction of Monroe is also erroneous. See 365 U.S. at 172, 183.) 
of them. ${ }^{166}$

\section{Conclusion Regarding Proposed Application of Existing Factors Relating to Unclear State Law and the Nature of the Federal Constitutional Issue}

The suggested abstention criteria provide a framework for applying the Pullman requirements that state law must be unclear and susceptible to an interpretation that would avoid a constitutional question. They provide more guidance than current statements of the requirements, which do not indicate with any consistency whether or not extreme ambiguity in state issues is required and which generally do not disclose the other variables in an abstention decision. But like current standards, the suggested criteria leave much room for individual judgment. Among the imprecise factors are the degree of unclarity of state law; the extent to which error might harm a state program; and the extent to which the federal constitutional issue is sensitive or, instead, calls for swift adjudication. For each of these inquiries there is obviously no principle by which one can pick any particular point of exactly how unclear, potentially harmful, sensitive, or in need of adjudication an issue must be to be determinative. Moreover cases can fall at all points along each relevant spectrum, and the spectra do not solve what may be the most difficult problem in many cases, which is where on a particular spectrum a particular issue should be placed; the solution to those problems will

To find no support for a civil rights exception to Pullman abstention is not, of course, to deny that exception to the administrative abstention doctrine, which will be discussed in text accompanying notes 250-53 infra.

${ }_{166}$ Rather than an exception for all $\S 1983$ cases, there could be one limited to particular types of actions, as the ALI apparently suggests. See note 161 supra. The one square holding of abstention in a $\S 1983$ case-Harrison v. NAACP, admittedly decided prior to McNeese-would probably fall within any exception that would be devised, as would most probably the facts of Pullman itself. The only suggestion by the Supreme Court of any absolute exception is language in Dombrowski v. Pfister, 380 U.S. 479, 489-90 (1965). There the Court, apparently discussing the propriety of Pullman abstention on the facts of that case, said "we hold the abstention doctrine is inappropriate for cases ... where ... statutes are justifiably attacked on their face as abridging free expression, or as applied for the purpose of discouraging protected activity." See also id. at 491-92. While that language would seem to suggest a per se rule against abstaining because of the nature of particular issues, in fact the reason abstention is inappropriate in that context, as the ensuing discussion in Dombrowski demonstrates, is that, in the Court's view, the basic requirements cannot be satisfied: The decision of the state issues cannot avoid the constitutional question. Accord. Baggett v. Bullitt, 377 U.S. 360 (1964). On whether the Court is correct in believing that the constitutional issue could not be avoided, see the cases cited in note 261 infra. 
depend on the particular substantive issues involved. A further fact preventing the suggested factors from showing with any precision a single correct course in each particular case is that there is no precise way to quantify the factors in order to relate them to each other. Accordingly, the suggested criteria would not result in consistent application of the abstention doctrine and indeed would permit judges to depart from the standards, intentionally or otherwise, without their departure being manifest. Intentional departures might result from judges wishing to take account of factors going to the merits of the cases but not embodied in the abstention criteria ${ }^{167}$ or simply from a distaste or disdain for the intellectual acrobatics involved in applying the suggested rules.

While a judge might justly recoil from applying the suggested standards, if their distinctions and subdistinctions are not deemed worth the energy they require, then Pullman abstention should not be perpetuated at all. For it simply does not seem worth imposing abstention's costs on the parties to order it more broadly than when functional analysis, applied in good faith, would suggest it is likely to serve a significant purpose. If the rule is to be simply that abstention may be ordered whenever a federal court believes state law is "unclear," then the chances of different state and federal results and the chances of any significant detriment resulting from a federal court decision do not seem great enough to warrant the delay and expense. ${ }^{168}$

167 While such an assertion is difficult to prove, there is some evidence in Supreme Court case law that the current lack of consistency in the degree of state law ambiguity required for abstention, see notes 76-78 supra, is attributable to the Justices' views of the merits. In Lake Carriers' Ass'n. v. MacMullan, 406 U.S. 498 (1972), a suit by owners of Great Lakes bulk cargo vessels to enjoin various sections of Michigan's Watercraft Pollution Control Act, Chief Justice Burger joined an opinion dissenting from the Court's order of abstention on the ground that the Michigan law, though unconstrued, was not ambiguous; that the plaintiffs have a right to choose a federal forum; and that they would be hurt by delay. Id. at 513-17. The dissenting position appears directly inconsistent with the Chief Justice's position in Wisconsin v. Constantineau, 400 U.S. 433 (1971), that the state should have the first opportunity to pass on its statute without regard to whether it was ambiguous. Similarly, some of the Justices in the MacMullan majority have seemed far less receptive to the abstention doctrine when the claimants challenge statutes allegedly abridging individual liberties than in the case in which an environmental protection statute was at issue. Compare Justice Brennan's opinion denying abstention in Zwickler v. Koota, 389 U.S. 241 (1967) with his opinion for the Court in Lake Carriers' Ass'n v. MacMullan, 406 U.S. 498 (1972).

${ }^{168}$ Another criticism that might be levelled at the suggested rules is that they could be wasteful in situations in which an appellate tribunal disagrees with a trial 


\section{E. A Proposal to Abandon the Requirement That the Case Must Contain a Federal Constitutional Issue}

The above suggestions for limiting Pullman abstention to cases in which it is likely to serve a valid purpose tend to narrow the range of cases within the authorization and construction categories that are appropriate for abstention. But the analysis of how the Pullman requirements apply in authorization cases reveals other respects in which Pullman abstention should not be as limited as it has been heretofore. As noted above, ${ }^{169}$ it suggests that the doctrine should not be limited to challenges to state enactments to the exclusion of state officials' conduct, if in fact it is so limited today. Moreover, it is logically inconsistent to abstain in authorization cases and at the same time to insist on the traditional Pulman requirement that, for abstention to be considered, decision of the unclear state issue must have the potential of avoiding a federal constitutional issue. There is no doubt that under current law Pullman abstention is impermissible in cases containing only state issues, ${ }^{170}$ and "[w] here a case involves a nonconstitutional federal issue ... the necessity for deciding which depends upon the decision on an underlying issue of state law, the practice in federal courts has been, when necessary, to decide both issues" even though "[t]he state law question [is] . . . concededly difficult and unsettled; [and] its decision admittedly control[s] the existence of a federal question . . ."171 The only apparent rationale for this limitation is that a purpose of Pullman abstention is to avoid, where possible, adjudicating federal constitutional issues and that abstention is proper only when it

judge's application of the rules and orders abstention after the trial judge has heard the case. But this problem is independent of the substantive standards for abstention. It exists under current law, as should be clear from Pullman where abstention was ordered after a three-judge court had passed on the merits. The problem is inherent if there are to be definitive standards and if a decision not to abstain is not reviewable until the conclusion of trial. See note 123 supra. It could be cured by allowing immediate review of such a decision (though that might itself be wasteful) or by allowing trial tribunals discretion always to hear a case in which abstention could have been ordered. The latter approach could be adopted consistently with retaining limits on the cases in which the district court could abstain.

${ }^{169}$ See text accompanying notes $146-51$ supra.

170 Meredith v. Winter Haven, 320 U.S. 228 (1943). Post-Pullman cases in which the Court has abstained despite the absence of any federal issue are explicable on grounds other than the Pullman doctrine. See text accompanying notes 174-76 \& 206-53 infra.

${ }^{171}$ Propper v. Clark, 337 U.S. 472, 490 (1949). 
may serve that purpose. But that rationale is at odds with those authorization cases, like Pullman itself, in which despite the presence of a federal constitutional question, the purpose of abstaining could not be to avoid it, because the district court had invalidated the challenged enactment under state law. If abstention is permissible in authorization cases in which the only purpose it can serve is to avoid interference with a state program, it would seem to follow that when that risk is present, a federal court should be permitted to abstain despite the absence of any constitutional issue in the case. ${ }^{172}$ Retention of Pulman abstention in authorization cases, therefore, calls for a rethinking of the general parameters of that doctrine. ${ }^{173}$

In Louisiana Power E Light Co. v. City of Thibodaux, ${ }^{174}$ abstention was ordered despite the absence of any federal issues. The city in that case sought to expropriate the land, buildings and equipment of the Louisiana Power \& Light Company. It sued in Louisiana court, but the company, which was incorporated in Florida, removed the case to federal court. One issue was whether under Louisiana law a city possessed the power of eminent domain; a Louisiana statute appeared to confer the power upon cities but a Louisiana attorney general had concluded that the power did not exist. The Supreme Court held that on those facts the district court did not err in staying the federal proceeding while the state courts were given an opportunity to construe the doubtful statute.

Thibodaux is a case in which it appeared that an erroneous federal decision on the unclear state issues might seriously affect the state. Its holding might suggest that abstention is

${ }^{172}$ The interest in avoiding federal constitutional adjudication does not extend to federal question cases in which the federal issue is not constitutional. In such cases, therefore, the federal court can proceed directly to the federal issue, particularly if it is dispositive, just as in cases involving clear and nonsensitive constitutional questions. Although Propper v. Clark, 337 U.S. 472 (1949), is to the contrary, abstention should be permissible on the state issues in such a case if they are unclear and if in the absence of abstention the federal court would limit or invalidate a state program.

${ }^{173}$ An alternative to broadening Pullman abstention is limiting it to construction cases in which conduct has not occurred, not an unreasonable approach since the hypothetical quality of federal decisions in that category of cases makes it the most appropriate category for abstention. See text accompanying notes 144-45 supra. Individual authorization cases, however, may warrant abstention more than particular construction cases in which conduct has not occurred, even those in which abstention is justly ordered. That fact cuts against differentiating the availability of abstention according to the appropriateness of categories instead of $\tilde{f}$ on a case-by-case basis. See note 151 supra.

174360 U.S. 25 (1959). 
in fact available on a showing simply that state law is unclear and that there is a danger that a federal court deciding the issue might harm an important state program. The Court did not adopt that rationale, however; rather than treating Thibodaux as a Pullman abstention case, it seemingly created an additional variety of abstention, limited perhaps to eminent domain cases. And since Thibodaux it has reiterated as a requirement of Pullman abstention that the state issue must be susceptible to a construction that would avoid a federal constitutional question. ${ }^{175}$ While it is not clear precisely what contours the Court intended to place on "Thibodaux abstention," a subject to be discussed further, ${ }^{176}$ the Pulman rationales would make abstention available on the facts of that case as readily as in Pullman itself. Abstention should be equally available if the federal court would, in the absence of abstention, invalidate the challenged provision; if the unclearness in the state law (and the consequent likelihood of federal error) is as great; if the program is as important to the state as the program in Pullman; and if the state could be equally harmed by delay caused in it. In both cases abstaining serves only the policy against wrongful interference with state programs, and that policy can be served equally whether or not there is any federal constitutional issue in the case.

\section{F. Possible Additional Pullman Requirements}

\section{A Requirement That the Suit Be One to Enjoin State Action}

The prototype Pullman abstention case involves an attempt to enjoin state action as unconstitutional. A limitation of Pullman abstention to suits to enjoin state officials would seemingly proceed on a theory that erroneous decisions in such suits

${ }^{175}$ E.g., Baggett v. Bullitt, 377 U.S. 360 (1964). It is not possible to interpret Thibodaux as allowing abstention simply when state law is unclear and to preserve this Pullman requirement without rendering the entire Pullman category superfluous.

Kaiser Steel Corp. v. W.S. Ranch Co., 391 U.S. 593 (1968), is another case in which the Supreme Court stayed its hand when no federal constitutional issue was present, without making clear how its holding fit within traditional Pullman requirements. The case may be an example of "Thibodaux abstention," or of administrative abstention, to be discussed later, see text accompanying notes 206-53 infra, or it may be explainable by the fact that a suit that would settle disputed state issues was pending in state court. See note 256 infra.

${ }^{176}$ See text accompanying notes 206-17 infra. 
could be especially harmful to the states. ${ }^{177}$ Any such limitation should, therefore, not apply when the interest to be served by abstaining is the federal interest in avoiding constitutional adjudication. Just as abstention should be permissible without regard to the presence of a constitutional issue if state law is unclear and a federal court ruling on it would disrupt a state program, so should the policy of avoiding unnecessary federal constitutional adjudication be sufficient for abstention in cases in which the federal court would decide unclear state issues in such a way that difficult or otherwise sensitive constitutional issues would remain.

The appropriateness of a requirement that the suit be one to enjoin state action in cases in which a purpose of abstaining is to avoid wrongful interference with the state depends upon whether erroneous federal court decisions will actually harm the state more in suits to enjoin state action than in suits in which no state official is a defendant, or even a party,

177 Under another theory, one could require an injunctive suit, but not require that state officials be the defendants. The federal courts' power to abstain in the face of congressional jurisdictional grants has often been deemed founded on the discretion inherent in equity jurisdiction. See, e.g., Burford v. Sun Oil Co., 319 U.S. 315, $317-$ 18 (1943); Pullman, 312 U.S. at 500-01; Harlow v. Ryland, 172 F.2d 784 (8th Cir. 1949). Such a rationale for abstention, though not an entirely satisfactory explanation, see note 66 supra, could limit it to injunctive suits. The Court has not adopted the limitation, however. It has abstained in simple damage actions without discussion of the issue. Fornaris v. Ridge Tool Co., 400 U.S. 41 (1970) (per curiam without argument); United Gas Pipe Line Co. v. Ideal Cement Co., 369 U.S. 134 (1962) (per curiam after argument). It addressed the issue in Louisiana Power \& Light Co. v. City of Thibodaux, 360 U.S. 25 (1959). There, in response to the objection that abstention was not proper because no equitable relief was sought, the Court said that

[a]lthough an eminent domain proceeding is deemed for certain purposes of legal classification a 'suit at common law', Kohl v. United States, 91 U.S. $367,375-76(1876)$, it is of a special and peculiar nature . . [I]t is intimately involved with sovereign prerogative ... A determination of the nature and extent of delegation of the power of eminent domain concerns the apportionment of governmental powers between City and State. The issues normally turn on legislation with much local variation interpreted in local settings. The considerations that prevailed in conventional equity suits for avoiding the hazards of serious disruption by federal courts of state government or needless friction between state and federal authorities are similarly appropriate in a state eminent domain proceeding brought in, or removed to, a federal court.

360 U.S. at 28. If, despite later application of the Pullman doctrine in damage suits, this were taken to imply that a suit must be in equity except when it is as analagous to an equitable proceeding as Thibodaux was, it would be difficult to see how far the exception to the equity requirement would extend. For the factors the Court relied on to draw the analogy to equity are not peculiar to eminent domain cases. Perhaps a declaratory judgment action, "essentially an equitable cause of action" in that a federal court exercises a discretion whether to grant relief, Great Lakes Dredge \& Dock Co. 
or in which injunctive relief is not sought. Louisiana Power $\mathcal{E}$ Light Co. v. Thibodaux ${ }^{178}$ would suggest that abstention is not limited to suits seeking injunctions against state action since the city was the plaintiff, not the defendant, in that case, and no injunction' was sought. Moreover, the Court has invoked Pulman abstention when the state was not a party at all, ${ }^{179}$ though it has given the issue little if any attention. ${ }^{180}$ Similarly, without discussing the issue, it has twice ordered Pullman abstention in actions for damages between private parties in which no injunctive relief was sought. ${ }^{181}$ Both were cases in which abstaining could serve the purpose of avoiding constitutional adjudication as well as protecting state interests, ${ }^{182}$ but the Court did not rely on that fact. And it seems that even when, as in Thibodaux, the purpose of abstaining is solely to avoid harm to the state, it is probably correct not to require that the suit be one to enjoin state action. ${ }^{183}$

It may generally be true that a state will suffer more interference from a federal pronouncement erroneously invalidating or limiting a state program if it is rendered in litigation in which the state is a defendant than when the state is either

v. Huffman, 319 U.S. 293, 300 (1943), would be sufficiently equitable. But in any event, abandonment of the equity requirement, as Fornaris and Ideal Cement suggest, would seem appropriate unless, as is explored in text, a suit in equity were more harmful to interests that abstention is designed to protect. A strict law-equity dichotomy, which would allow the plaintiff in his choice of remedy to affect decisively the abstention question, would not seem functional, since the abstention doctrine does not exist to protect plaintiffs' interests.

178360 U.S. 25 (1959).

${ }^{179}$ E.g., Fornaris v. Ridge Tool Co., 400 U.S. 41 (1970); United Gas Pipe Line Co. v. Ideal Cement Co., 369 U.S. 134 (1962); $c f$. Kaiser Steel Corp. v. W.S. Ranch Co., 391 U.S. 593 (1968) (state court proceeding on disputed issue pending); Clay v. Sun Ins. Office, 363 U.S. 207 (1960) (certification). Lower courts also have abstained in actions between private parties. E.g., Barrett v. Atlantic Richfield Co., 444 F.2d 38 (5th Cir. 1971); Warren v. Government Nat'l Mortgage Ass'n, 443 F.2d 624 (8th Cir. 1971), cert. denied, 404 U.S. 886 (1971).

${ }^{180}$ Justice Brennan did advert to the issue whether the suit was one to enjoin state action in his Thibodaux dissent, 360 U.S. at 34-35, and to the injunction issue in his opinion for the Court in County of Allegheny v. Frank Mashuda Co., 360 U.S. 185,190 (1959). One should compare his concurring statement in Kaiser Steel, 391 U.S. at 594-95, and note that he joined in the Court's per curiam decisions in Ideal Cement and Fornaris.

${ }^{181}$ Fornaris v. Ridge Tool Co., 400 U.S. 41 (1970); United Gas Pipe Line Co. v. Ideal Cement Co., 369 U.S. 134 (1962).

${ }^{182}$ Fornaris and Ideal Cement are construction cases in which it appears abstention could serve either or both abstention policies.

${ }^{183}$ But see ALI STUDY, supra note 33, at 286: "In a suit between private litigants, a mistaken determination of state law by the federal court, obviating consideration 
plaintiff in the action or is not a party at all. The state is directly bound by a judgment to which it is a party as it is not when litigation is between private parties. And when the state is a defendant in an action, the court's judgment may be so broad as to delay state enforcement of a program against more than the parties to the suit; the judgment also may shield persons situated similarly to the plaintiff. ${ }^{184}$

The lines between the three situations in which the state may find itself - a defendant, a plaintiff, or, not a party-are not, however, absolute. Although a state as plaintiff will be bound ${ }^{185}$ only in relation to the party to the suit, it is readily conceivable that the very suit may involve extremely important state interests. If immediate expropriation of the Power \& Light Company's property was important to the city in Thibodaux, for example, then erroneous delay in that expropriation could seriously affect it even though the erroneously enunciated rule of law was not elsewhere applied. And when the state is in a defensive posture, the issues can be sufficiently peculiar to the particular controversy that there is no serious probability of a federal order affecting its relations with other than the plaintiff in the case. That may have been the situation in County of Allegheny v. Frank Mashuda Co., ${ }^{186}$ a suit against the state involving the eminent domain power, in which diversity was the basis of federal jurisdiction; the Supreme Court decided Mashuda the same day it decided Thibodaux, but in $M a$ shuda it declined to abstain. The plaintiff in Mashuda contended that the county had taken its property for a private use, which was illegal under state law. If a ruling that Mashuda's property was taken for a private use rested on grounds peculiar to that company's controversy with the county, ${ }^{187}$ then whether the state subdivisions could be more harmed by an erroneous federal ruling on state law in Thibodaux or in Mashuda would turn solely on whether the condemnation in one case was

of the constitutional issue, is not of great importance. In litigation to which the state is a party, it is of more significance."

${ }^{184}$ See note 89 supra.

185 Bound, that is, until a corrective state ruling is obtained and the federal decree is reopened to reflect its result.

186360 U.S. 185 (1959).

${ }^{187}$ Justice Brennan's opinion for the Court indicates that the ruling might well rest on such grounds, for it says that the only issue in the case is the "factual" one. 360 U.S. at 190. 
more important to the state subdivision than in the other. It would be unaffected by the fact that the state subdivision was plaintiff in Thibodaux and defendant in Mashuda.

Similarly a state can be harmed by an erroneous federal court ruling in a case involving only private parties, even though its officials are not bound by the judgment. ${ }^{188}$ United Gas Pipe Line Co. v. Ideal Cement Co. ${ }^{189}$ for example, concerned the construction and federal constitutionality of a state taxing provision. ${ }^{190}$ If a federal court erroneously struck down that tax, a hiatus in its payment might leave the state as harmed as in many cases in which it is defendant. Accordingly, it is more sensible to have a rule to be applied on a case-by-case basis that for abstention to be ordered there must be a risk that an erroneous federal ruling would severely hurt the state's interests, than it is to have any absolute requirement that the state must be party to, or defendant in, the suit. ${ }^{191}$

Nor is it clear that the state's interests are necessarily more harmed if an injunction, instead of some other kind of

${ }^{188}$ This is especially likely in cases in which private party litigation is an important means of enforcement of a scheme designed to protect state interests.

${ }^{189} 369$ U.S. 134 (1962).

${ }^{190}$ The plaintiffs sought contractual reimbursement for city taxes they had paid pertaining to sales to the defendants, and the defense focused on the federal unconstitutionality of the city tax in question.

191 The Court has not necessarily limited abstention in cases between private litigants to circumstances in which states' interests could suffer from erroneous state law rulings. In Fornaris v. Ridge Tool Co., 400 U.S. 41 (1970), the issue between the parties did not risk delaying a state program in a way that would greatly harm the state if the federal court erred, but in any event abstaining there, as in United Gas Pipe Line Co. v. Ideal Cement Co., 369 U.S. 134 (1962), served the purpose of avoiding constitutional adjudication as well as avoiding interference with the state. In Kaiser Steel Corp. v. W.S. Ranch Co., 391 U.S. 593 (1968), a nonconstitutional case involving only private parties in which the Court deferred to state adjudication, the Court noted that the case involved water, "a vital state resource," 391 U.S. at 594, but it is difficult to imagine that the state would be seriously harmed in a manner that a federal court should take cognizance of if the federal court erred. One company which had been given water rights by the state claimed a right to use the plaintiff's land as an incident to exercising those water rights. The plaintiff company claimed that so to condemn its land for the use of another private company would violate state constitutional commands that condemnation is legitimate only if for "public use." While the suit involved water, the issues in the suit did not therefore pertain to the allocation of that "vital state resource." 391 U.S. at 594. An erroneous federal ruling would either wrongly deprive the private company of its access to water or would wrongly limit the state's ability to condemn for the benefit of private companies-an interest probably not so central to the state that a hiatus would do the state severe harm. Kaiser can be explained, however, by the fact that a state proceeding on the condemnation issue was pending. See note 256 infra.

For a case in which the court in abstaining noted that the effect on state economic policy of an erroneous ruling would be great, even though the case involved private 
relief, is sought. ${ }^{192}$ Even limiting the cases to those in which the state is a defendant, ${ }^{193}$ it is not clear that the state, or its official or agency, is significantly more limited by an injunction than by a declaratory judgment. ${ }^{194}$ Although declaratory relief is not of itself coercive and does not carry the contempt sanction, the parties will ordinarily heed it, and it is issued on that supposition. If it is violated, an injunction should ordinarily follow without a retrial on- the merits since the earlier litigation, through res judicata or collateral estoppel, would seemingly govern the issue. ${ }^{195}$

\section{The State's Consent As a Precondition to Abstention}

\section{a. A Requirement that State Officials Consent to Abstaining in the Particular Case}

In Thibodaux and in some Pullman abstention cases, ${ }^{196}$ the federal court has raised the issue of abstention sua sponte. Indeed, in Thibodaux the city opposed abstention and the party that had sought the federal forum supported abstention before

litigants, see Union Carbide \& Carbon Corp. v. White River Distribs., Inc., 118 F. Supp. 541, 550 (E.D. Ark. 1954).

${ }_{192}$ Injunctive and declaratory proceedings will be the principal forms of unconsented relief against the state. Suits for damages to be paid out of state funds cannot be maintained against state officials without the state's consent, Edelman v. Jordan, 94 S. Ct. 1347 (1974); Great Northern Life Ins. Co. v. Read, 322 U.S. 47, 52 (1944), and the state can limit any consent to suit in state courts, Smith v. Reeves, 178 U.S. 436,445 (1900). Although cities and counties are subject to federal court suit without their consent, Chicot County v. Sherwood, 148 U.S. 529 (1893); $c f$. Workman v. City of New York, 179 U.S. 552 (1900), they are immune to the extent that state law is determinative of liability, e.g., Broward County v. Wickman, 195 F.2d 614 (5th Cir. 1952), and they are not liable in damage actions under 42 U.S.C. $\S 1983$, Monroe v. Pape, 365 U.S. 167 (1961). Suits for return of specific property in custody of the state but claimed to belong to the plaintiff can be maintained against state officials without the state's consent. Land v. Dollar, 330 U.S. 731 (1947). The measure of the harm to the state's interests in such cases is the value of the property to be retrieved.

${ }^{193}$ Only in those cases would the existence of a request for an injunction seem even arguably to affect the degree to which an erroneous ruling might harm the state.

194 The Supreme Court has recognized in other contexts that a declaratory judgment can interfere with a state program in the same way an injunction does. Samuels v. Mackell, 401 U.S. 66, 69-74 (1971); Great Lakes Dredge \& Dock Co. v. Huffman, 319 U.S. 293, 299 (1943). But see Perez v. Ledesma, 401 U.S. 82, 111-16, 122-28 (1971) (Brennan, J., concurring and dissenting); Mitchell v. Donovan,-398 U.S. 427, 429-30 (1970); Kennedy v. Mendoza-Martinez, 372 U.S. 144, 152-54 (1963).

${ }^{195}$ See Samuels v. Mackell, 401 U.S. 66, 72 (1971). But cf. Perez v. Ledesma, 401 U.S. 82, 125 (1971) (Brennan, J., concurring and dissenting).

${ }^{196}$ E.g., England v. Louisiana State Bd. of Medical Examiners, 375 U.S. 411 (1964). Several Justices in Wisconsin v. Constantineau, 400 U.S. 433 (1971), similarly raised the issue of abstention in dissenting opinions. 
the Supreme Court. ${ }^{197}$ When the purpose abstention is to serve is avoiding federal constitutional adjudication, it seems appropriate that abstention be considered at the request of either party or on the motion of the federal court itself. ${ }^{198}$ But when the purpose of abstaining is to protect state interests, the state should be able to waive the protection. If, as it appears, that was the purpose of abstaining in Thibodaux, it was error to do so over the state's protest.

\section{b. A Requirement of Adequate State Remedies}

It is settled that a federal court can order abstention only if the state provides the parties with adequate means to adjudicate the controverted state law issue. ${ }^{199}$ (The case law is less than clear, however, as to which remedies are adequate.) ${ }^{200}$ One situation in which state remedies may be deemed inade-

197360 U.S. at 42-44 (Brennan, J., dissenting). Delay-and accordingly abstention -benefited the defendant company, which retained possession of its property during the proceedings. Cf. Hostetter v. Idlewild Bon Voyage Liquor Corp., 377 U.S. 324, 329 (1964).

${ }^{198}$ A private litigant might be indulging simply in a strategy of delay or might have a genuine interest in state court decision of state issues, on the assumption that the outcome would benefit him and would differ from a federal court's result. But when in an authorization case the only interest to be served is avoiding constitutional adjudication, a state raising the abstention issue would be serving only purposes of delay, because it would be arguing against the validity of the enactment it was defending. The state's failure in Wisconsin v. Constantineau to request abstention on the ground that the challenged provision might violate the state constitution is thus explicable as a recognition by the state that its interests in preserving the challenged statute would be no better served by its invalidation under state than under federal law.

Because legitimate state purposes do not argue for abstention in such a context, a federal court, in order to serve the federal purpose of avoiding unnecessary constitutional adjudication, must have power to consider abstention on its own motion. The power must extend to considering a state law ground for invalidation of a challenged enactment although the plaintiff has not raised that issue at all; otherwise the plaintiff, whose interests abstention is not designed to serve, would control abstention by his pleading. Thus in both Constantineau and England the parties had not raised the state law claim; the court had to raise the issue sua sponte, if abstention was to fulfill its federal purpose. Cf. McNeese v. Board of Educ., 373 U.S. 668 (1963). Presumably having raised the state law claim, the district court can itself decide the suit on that ground, if the state issue is sufficiently clear or is otherwise inappropriate for abstention.

${ }^{199}$ As early as Pulman the Court emphasized in abstaining that "[t]he law of Texas appears to furnish easy and ample means for determining the Commission's authority." 312 U.S. at 501.

${ }^{200}$ The state procedure should be deemed inadequate whenever it is so cumbersome that the individual litigant suffers substantial prejudice in addition to that necessarily accompanying the abstention procedure. There are many ways in which the state procedure for resolving the state law issue may so cause the litigant preju- 
quate, so that the parties will be permitted to pursue their action in federal court, is where the state courts will not decide the disputed issue subject to the limitations the abstention doctrine would impose on their adjudication. In Pullman cases,

dice. Even if the state has a declaratory judgment procedure which allows access to state adjudication whenever there is a justiciable controversy, there may, for example, be peculiarly long delays involved which could support an allegation that the remedy is inadequate. The state remedy may also be inadequate if no declaratory relief is available. In such a case, the inquiry would be whether the parties are significantly prejudiced by whatever alternative does exist. Pullman indicates that the fact that the plaintiff in the federal action will be in the defensive position in the state litigation is not alone sufficient to render the state remedy inadequate. One of the proceedings the Court there noted in saying Texas afforded "adequate relief" was an "action on the part of the State to enforce obedience to the order." Id. The Court also apparently presumed in favor of the adequacy of the state remedy, placing on the objecting party the burden of coming forward with a showing that the available means "cannot be pursued with full protection of the constitutional claim." Id.

Despite this language, it is questionable that a litigant should be required to undergo a criminal proceeding or otherwise risk heavy penalties under the Pullman abstention doctrine. Certainly if he has not already acted to make himself criminally liable, he should not be required to do so as a precondition to state adjudication, and a state "remedy" that requires him to do so should be deemed an inadequate substitute for federal adjudication; a central purpose of the Federal Declaratory Judgment Act, 28 U.S.C. §§ 2201-02 (1970), is "to avoid accrual of avoidable damages to one not certain of his rights and to afford him an early adjudication without waiting until his adversary should see fit to begin suit, after damage has accrued," E. Edelmann \& Co. v. Triple-A Specialty Co., 88 F.2d 852, 854 (7th Cir.), cert. denied, 300 U.S. 680 (1937). See note 288 infra \& accompanying text. Dombrowski v. Pfister, 380 U.S. $479,489-92$ (1965), would indicate, however, that in the case of a litigant who is already criminally liable, abstention under the Pullman doctrine in favor of a state criminal proceeding may be proper. There the Court discussed the possibility of abstention-seemingly referring to Pullman abstention-when the contemplated state proceeding was a criminal prosecution. It seemingly declined to abstain there because the state issue was such that the constitutional question could not be avoided and not because criminal proceedings were an inappropriate forum for the state adjudication. But if the issues had been appropriate for abstention, one wonders whether the Court would have ordered it in that setting in view of the England procedure, which clearly gives a federal plaintiff the right to reserve federal issues for the federal court. Surely those issues could not constitutionally be excised from a criminal proceeding. The only way to preserve the plaintiff's England rights and also abstain for litigation of state issues in a criminal proceeding would seem to be to allow the federal plaintiff to litigate all issues in the state prosecution and then to relitigate federal issues in federal district court. It is not clear whether England sanctions that approach, see 375 U.S. at 421-22 \& n.12, but it does not seem substantially to prejudice the federal plaintiff over and above the prejudice he generally suffers in Pullman abstention. Moreover, the federal relitigation would seem in keeping with usual federal habeas corpus practice, being broader only in extending a right to a factual hearing in federal court without regard to the adequacy of the state court hearing. Cf. England, 375 U.S. at 417 n.8. In any event, Pullman issues may never be reached in many cases in which a federal plaintiff, by the time of his federal suit, is already liable to criminal sanctions, because of the other type of "abstention" at issue in Dombrowski v. Pfister, which will be discussed below at text accompanying notes 254-328 infra. 
the England procedure arguably forbids state courts to decide federal issues without the parties' consent; ${ }^{201}$ in Thibodaux they are left only the unclear issue of state law. Some states, however, adhere to limitations which prohibit their courts from ruling on state law issues unless they have jurisdiction of the entire controversy. ${ }^{202}$ Under existing doctrine it would seem improper for a federal court to abstain in favor of state courts that under such a limitation will not hear the controversy; instead, the federal court should proceed with its own adjudication. ${ }^{203}$

Such a rule would allow the states to veto abstention by failing to provide necessary procedures even when the purpose of abstaining is to serve the federal interest against unnecessary constitutional adjudication, in apparent contradiction of the rationale suggested above for sua sponte abstention. It may not be inconsistent, however, to hold that while a state cannot always bar abstention by declining to raise the issue at trial, it can always block it by declining to provide the requisite

${ }^{201}$ See 375 U.S. at 421-22 n.12. An alternative reading is that state courts may decide federal issues, but if they do so without the parties' consent, the parties may religate them de novo in federal court.

${ }_{202}$ See United Services Life Ins. Co. v. Delaney, 396 S.W.2d 855 (Tex. 1965); cf. Leiter Minerals, Inc. v. California Co., 241 La. 915, 132 So. 2d 845 (1961); In re Richards, 223 A.2d 827 (Me. 1966). See also 48 Iowa L. Rev. 185 (1963); 40 Texas L. Rev. 1041 (1962).

The problem is that some state courts have interpreted a restriction on their jurisdiction to the decision of "cases and controversies" to mean that they cannot decide a case unless they have power to dispose of it. When the federal court abstains for decision of state issues, the state court cannot necessarily dispose of the case. In Pullman, for example, the Texas courts would dispose of the case only if they held the Commission's order was not authorized. If they held it authorized, the disposition of the controversy would depend upon the resolution of the federal constitutional question. Since England it has been clear that, absent a waiver by the parties, they have a right to have that issue determined in the federal forum.

${ }^{203}$ See England v. Louisiana State Bd. of Medical Examiners, 375 U.S. 411, 421-22 n.12 (1964). Cf. ALI STUDY, supra note 33 , at 286, 294-96 (certification). The alternative of litigating the federal issues in both the state and the federal fora is discussed in note 200 supra. It is worth noting that if federal courts adopted the alternative and abstained in favor of state courts that had announced they would decline to decide state issues alone, persons claiming federal constitutional violations should never consent to have them heard in the state court that nevertheless would hear them. By refusing their consent, those litigants would retain the right wholly to litigate their claims in two separate fora and thus would increase their chance of victory.

In Barrett v. Atlantic Richfield Co., 444 F.2d 38, 45-46 (5th Cir. 1971), Judge Wisdom implies that the correct approach for a federal court faced with a case where state courts will not confine themselves to state issues but which otherwise warrants Pullman abstention is to abstain but dismiss the case rather than retain jurisdiction. Presumably that would solve the state courts' problem only if the difference in disposition were deemed to allow the state courts to pass upon federal claims. Dismissing 
procedures. For the federal system to tell the states that they must provide a procedure for the adjudication of single issues would be a fairly radical interference with state decisionmaking. ${ }^{204}$ Since state procedural limitations affect more than abstention cases, it may be thought that the state interest in deciding what those limitations should be outweighs any federal interest in avoiding federal constitutional adjudication in particular cases.

This analysis would indicate a different result, however, if the state does not have a general principle against deciding less than an entire case but unreasonably delays or otherwise hampers the adjudication of a particular case. When that is the sense in which the state provides inadequate procedures, only federal reluctance to subject state courts to compulsion can explain declining to require them to proceed expeditiously in cases in which the purpose of abstaining is to serve the federal interest.

\section{PART TWO: THE RELATION OF PULLMAN ABSTENTION TO OTHER TYPES OF ABSTENTION}

The term "abstention" is used indiscriminately to refer to several quite distinct doctrines, ${ }^{205}$ only one of which is Pullman abstention. Partly because of the confusion of terminology, and partly because the limits of the other categories of abstention are largely incoherent, the relationships between the various categories are less than clear. Whether it is proper to treat any particular case in accordance with the Pullman doc-

Pullman cases does seem to contravene England. But see 444 F.2d at 45 n.3. Nevertheless, in Barrett there was an independent reason both for dismissing rather than retaining jurisdiction and for leaving federal as well as state issues to the state system: that the case qualified for administrative abstention as well as meeting Pullman requirements. See text accompanying notes 221-23 infra; note 242 infra \& accompanying text.

${ }^{204}$ Moreover, the federal system should be rather sympathetic to such state limitations, both because article III of the Federal Constitution contains similar restrictions and because the purpose of such restrictions appears to be improving the quality of judicial decisionmaking. Indeed it may be that federal constitutional limitation which is primarily responsible for the absence of a counterpart to the Pullman abstention doctrine for cases litigated in state courts which contain very unclear federal issues that are potentially controlling. Another explanation for the absence of any procedure whereby state courts could refer such issues to federal court lies in the possibility of Supreme Court review of erroneous federal determinations; but the pressures on the Court's docket and the consequent difficulty of obtaining review may make that explanation insufficient.

${ }^{205}$ C. A. WRight, Federal Courts 196 (1970). 
trine or instead to place it within another abstention category is not always obvious, although that decision can be of enormous consequence to the determination of the proper forum. Moreover, the rationales behind the other categories of abstention are in some respects inconsistent with the Pullman rationales. This section will attempt briefly to delineate the scope of the various abstention categories; to show the respects in which the coexistence of the various categories is inconsistent with the limits upon Pullman abstention; and, finally, to address the question how, if all the categories of abstention are to persist, a court should decide which doctrine comes into play in any given situation.

\section{I. "ThiBODAUX ABSTENTION"}

Louisiana Power E Light Co. v. City of Thibodaux ${ }^{206}$ is the controlling case in this category, a category that would be rendered superfluous if the previously suggested approach of eliminating the requirement of a constitutional issue were adopted for Pullman abstention. The Court in Thibodaux did not take this approach, however, but purported to create a supplemental Thibodaux category of uncertain scope. The difficulty in determining its scope is compounded by the decision the same day reversing a district court dismissal in County of Allegheny v. Frank Mashuda Co. ${ }^{207}$ While much in Thibodaux suggests a rule of abstention peculiar to eminent domain

206360 U.S. 25 (1959); see notes 174-76 supra \& accompanying text.

${ }^{207} 360$ U.S. 185 (1959); see notes 186-87 supra \& accompanying text. It is not surprising that the cases are difficult to reconcile, since seven of the nine Justices sitting on the two cases disagreed with the holding of one of them, and the author of each opinion dissented in the other. In fact Justice Brennan's opinion for the Court in Mashuda bears a marked resemblance to the vigorous dissent he voiced in Thibodaux. Only Justices Stewart and Whittaker joined in both majority opinions, and only Stewart gave an explanatory statement. He said he concurred in Thibodaux because it "was clearly within the District Court's allowable discretion" for it to defer "immediate adjudication of this controversy pending authoritative clarification of a controlling state statute of highly doubtful meaning." He went on to say:

This case is totally unlike County of Allegheny v. Mashuda Co., decided today ... except for the coincidence that both cases involve eminent domain proceedings. In Mashuda the Court holds that it was error for the District Court to dismiss the complaint. The Court further holds in that case that, since the controlling state law is clear and only factual issues need be resolved, there is no occasion in the interest of justice to refrain from prompt adjudication.

360 U.S. at 31. 
cases, ${ }^{208}$ abstention was refused in Mashuda, which also involved eminent domain, and language in Mashuda states that there is nothing special about eminent domain for abstention purposes. ${ }^{209}$ Mashuda and Thibodaux might be reconcilable on the ground that the state's interests would be more adversely affected by an erroneous ruling against the state in one instance than the other, ${ }^{210}$ but the Court's opinion does not rest on any such distinction. Another distinguishing feature is that state law was unclear in Thibodaux and it was relatively clear in Mashuda. ${ }^{211}$ But that is the rationale that cannot alone explain Thibodaux abstention without rendering superfluous the Pullman category with its requirement of a constitutional ques-

${ }^{208}$ The Court referred to the problem involved in the case as one generic to eminent domain cases when it said, "We granted certiorari . . . because of the importance of the question in the judicial enforcement of the power of eminent domain under diversity jurisdiction." 360 U.S. at 26. It went on to mention that the Court had been closely divided in the decision in which, in 1905, it allowed eminent domain cases in federal courts at all under the diversity jurisdiction. Madisonville Traction Co. v. St. Bernard Mining Co., 196 U.S. 239 (1905). It quoted with approval from Justice Holmes' dissent in that case concerning the plenary power of the state over eminent domain and emphasized "the distinction between expropriation proceedings and ordinary diversity cases." 360 U.S. at 26 . The Court then said abstention was not precluded because the suit was not in equity, because it was an eminent domain suit. See language quoted in note 177 supra. See also note 213 infra.

One could, however, interpret the Court's discussion of eminent domain in Thibodaux as relating solely to whether a suit must be in equity for abstention to be permissible, see note 177 supra, and not suggesting that eminent domain was a factor in any other sense in a decision whether to abstain.

209 "[T] $]$ he fact that a case concerns a State's power of eminent domain no more justifies abstention than the fact that it involves any other issue related to sovereignty. Surely eminent domain is no more mystically involved with 'sovereign prerogative' than ... a host of other governmental activities carried on by the States and their subdivisions which have been brought into question in the Federal District Courts despite suggestions that those courts should have stayed their hand pending prior state court determination of state law."

360 U.S. at 191-92; see id. at 192-96.

${ }^{210}$ See text accompanying notes $186-87$ supra. Moreover, the fact that the state law issue in Thibodaux was more generalized than that in Mashuda, and thus less likely to affect only the particular litigants, may have made state court discrimination against out-of-staters less likely in Thibodaux than in Mashuda. Accordingly, the breach in the exercise of diversity jurisdiction would seem less problematic in Thibodaux.

${ }^{211}$ A variant on this explanation is the suggestion made in Justice Stewart's Thibodaux concurrence and in Justice Brennan's opinion for the Court in Mashuda that the only issues in Mashuda were factual. Whether that is a correct characterization of the Mashuda issues is, however, open to doubt. The facts concerning the use to which the condemned property had been put in Mashuda were fairly clear. The question to be decided was whether Pennsylvania law would characterize that use as "public" or "private". 
tion. ${ }^{212}$ Probably the most satisfactory way to explain the two holdings is to conclude that Thibodaux abstention is proper in eminent domain cases to elucidate unclear issues of state law; neither eminent domain nor unclear state law is sufficient for abstention, but the two in combination are. ${ }^{213}$ The reconciliation is not problem-free, however. Mashuda's language that there is nothing peculiar about eminent domain proceedings is contradicted. ${ }^{214}$ And the only statement given by a Justice

212 One might argue that unclear state law is determinative in Thibodaux and that it still does not displace Pullman by saying unclear state law is sufficient for abstention only in cases not involving any federal issue. But that position is either irrational in its limitation to non-federal question cases, or it constitutes a direct undercutting of the diversity jurisdiction by deeming private litigants' interest in not having their case determined according to an erroneous view of state law sufficient to displace federal jurisdiction in diversity cases alone. In a pre-Thibodaux case, Meredith v. Winter Haven, 320 U.S. 228 (1943), the Supreme Court said that such a position would be contrary to the diversity jurisdiction. Cf. Burford v. Sun Oil Co., 319 U.S. 315, 336 (1943) (Frankfurter, J., dissenting); Alabama PSC v. Southern Ry., 341 U.S. 341, 351 (1951) (Frankfurter, J., concurring). But cf. Kaiser Steel Corp. v. W.S. Ranch Co., 391 U.S. 593 (1968); Hawks v. Hamill, 288 U.S. 52 (1933) (alternative holding). See also Louisiana Power \& Light Co. v. City of Thibodaux, 360 U.S. 25, 31 (1959) (Brennan, J., dissenting). Moreover, in Thibodaux the Court seems to have denied any such general undercutting of the diversity jurisdiction when it spoke of "the distinction between expropriation proceedings and ordinary diversity cases." 360 U.S. at 26.

Much has been written on whether difficult questions of state law are sufficient to justify abstention in cases not involving any federal issue, see, e.g., C. A. Wright, FedERAI Courts 202-03 (1970); Currie, The Federal Courts and The American Law Institute, 36 U. Chi. L. Rev. 268, 313-14 (1969); Liebenthal, A Dialogue on England: The England Case, Its Effect on the Abstention Doctrine, and Suggested Solutions, 18 WESTERN REs. L. Rev. 157, 158 n.2, 183-95 (1966); Comment, Recent Developments in the Doctrine of Abstention, 1965 Duke L.J. 102; Comment, Abstention Under Delaney: A Current Appraisal, 49 Texas L. Rev. 247 (197I); Comment, Abstention and Certification in Diversity Suits: "Perfection of Means and Confusion of Goals," 73 Y ALE L.J. 850 (1964); a question on which the courts of appeal are in conflict. Compare United States Life Ins. Co. v. Delaney, 328 F.2d 483 (5th Cir. 1964) (abstaining) with Martin v. State Farm Mut. Ins. Co., 375 F.2d 720, 722 (4th Cir. 1967) (not abstaining) and In re Mohammed, 327 F.2d 616, 617 (6th Cir. 1964) (not abstaining). The bulk of authority is unfavorable to abstention which serves only the interest of protecting private litigants against the risk of an erroneous state law ruling by a federal court in their particular case.

The existence of diversity jurisdiction does not, however, affect the propriety of other categories of abstention; the issue regardless of diversity is whether the abstention requirements are met. See, e.g., United Gas Pipe Line Co. v. Ideal Cement Co., 369 U.S. 134 (1962); Burford v. Sun Oil Co., 319 U.S. 315 (1943). This is true even though an argument could be made that abstention is per se improper in a case in which the parties are diverse because state courts' bias against out-of-staters keeps them from being more likely than the federal system to reach correct results, despite their general superiority in interpreting state law.

${ }^{213}$ The language of the Court's holding in Thibodaux supports this reading: "The special nature of eminent domain justifies a district judge, when his familiarity with the problems of local law so counsels him, to ascertain the meaning of a disputed state statute from the only tribunal empowered to speak definitively-the courts of the State under whose statute eminent domain is sought to be exercised-rather than himself make a dubious and tentative forecast." 360 U.S. at 29.

${ }^{214}$ Moreover, in seeking to distinguish Meredith v. Winter Haven, 320 U.S. 228 
voting with the majority in both cases de-emphasized the role of the eminent domain factor, calling it a "coincidence" that both cases involved that power, and focused instead on the difference in the clarity of state law in the two cases. ${ }^{215}$ At any rate, since it is difficult to see what in the eminent domain power warrants such special treatment for abstention purposes, it is difficult to predict what other subjects of state power, if any, will be deemed to fall within an abstention category where ambiguity of state law is sufficient for abstention. ${ }^{216}$

(1943), the leading case for the rule that uncertainty in state law does not by itself justify abstention, the Thibodaux Court did not rely on the special nature of an eminent domain proceeding. 360 U.S. at 27 n.2. For the distinction it did adopt, see note 215 infra.

${ }^{215}$ See Justice Stewart's opinion quoted in note 207 supra. Justice Stewart seems to stress also two other points: the district court's discretion on the abstention issue and the difference in the dispositions of Mashuda, where the district court dismissed, and of Thibodaux, where the court retained jurisdiction. The same two reasons were used by Justice Frankfurter in his opinion for the Court in Thibodaux to distinguish the Supreme Court's holding in Meredith v. Winter Haven. 360 U.S. at 27 n.2. Though the Court often speaks of abstention decisions as involving discretion, e.g., Harman v. Forssenius, 380 U.S. 528, 534, 537 (1965), it seems difficult to explain abstention decisions by discretion on the part of the district judge, when the Supreme Court reverses both district court orders granting abstention, e.g., Mashuda; Griffin v. County School Board, 377 U.S. 218 (1964); Turner v. City of Memphis, 369 U.S. 350 (1962), and district court denials of abstention, e.g., Pullman \& Harrison v. NAACP, 360 U.S. 167 (1959), and does not seem in any cases to allow the trial court's result to stand simply because the trial court so ruled. $C f$. Clay v. Sun Ins. Office, 363 U.S. 207, 223 n.17 (1960) (Black, J., dissenting). Conceivably, discretion to abstain or not if state law is unclear could be the rule in "Thibodax abstention" though not in Pullman cases, but any rationale for allowing it would seem to apply in one category as much as the other.

Stewart's and Frankfurter's focus on whether the district judge retained jurisdiction also seems misplaced. If the only way the district judge had erred in Mashuda or Meredith was in dismissing the action rather than retaining jurisdiction pending state proceedings, the Supreme Court should have simply changed that disposition without implying that the district court should proceed to adjudicate the entire case.

${ }^{216}$ There is one suggestion in the Court's opinion of a category larger than eminent domain. In stating the proper law the Court said:

[W]e have held that the mere difficulty of state law does not justify a federal court's relinquishment of jurisdiction in favor of state court action. Meredith v. Winter Haven, 320 U.S. 228, 236. But where the issue touched upon the relationship of City to State, Chicago v. Fieldcrest Dairies, Inc., 316 U.S. 168, or involved the scope of a previously uninterpreted state statute which, if applicable, was of questionable constitutionality, Leiter Minerals, Inc. v. United States, 352 U.S. 220, 229, we have required District Courts, and not merely sanctioned an exercise of their discretionary power, to stay their proceedings pending the submission of the state law question to state determination.

360 U.S. at 27-28 (footnote omitted; emphasis added).

The category suggested-that of cases involving the relationship between cities and the state-does not seem any more rational than a category of eminent domain cases alone. Of course, the state has plenary power over that subject matter, but it 
In the end, one is left with an impression that the limits of "Thibodaux abstention," as a separate category, are indiscernable. ${ }^{217}$ The proper resolution of this confusion, as suggested above, ${ }^{218}$ would be to merge Thibodaux and Pullman abstention, making unclear state law sufficient in all cases in which a state program may be significantly harmed by an erroneous federal decision.

Even if it continues to be treated as a separate abstention category, however, the limits of Thibodaux abstention are not of importance to persons invoking Pullman abstention, for the consequences of each type of abstention are similar: In Thibodaux, as in Pullman, the Court ordered that jurisdiction be retained and eventually exercised on all but the unclear state issue. ${ }^{219}$ Accordingly, even if there were some seeming overlap between the categories-if, for example, Thibodaux were deemed to apply to eminent domain cases with unclear state issues

has such power over all the subjects in question in these cases as long as it does not act unconstitutionally. The category is vulnerable also to the other criticisms Justice Brennan leveled against a category of eminent domain cases in his Thibodaux dissent and in Mashuda. One case that may possibly be explainable as a non-eminent domain version of Thibodaux abstention is Kaiser Steel Corp. v. W.S. Ranch Co., 391 U.S. 593 (1968). See note 175 supra.

217 The use lower courts have made of Thibodaux confirms this impression. There are cases adopting the reading of Supreme Court case law that Thibodaux abstention applies to eminent domain proceedings, and its propriety there depends upon whether state law is clear or ambiguous. See Mayor \& City Council v. National Dairy Prod. Corp., 193 F. Supp. 556 (D.Md. 1961) (abstention not ordered because state law clear); Myrick v. Union Oil Co., 418 F.2d 135 (9th Cir. 1969) (abstention not ordered because state law clear); Crawford v. Courtney, 451 F.2d 489 (4th Cir. 1971) (abstention ordered). Other cases indicate that Thibodaux abstention can be ordered in areas "intimately involved with sovereign prerogative," 360 U.S. at 28, other than eminent domain. John L. Burns, Inc. v. Gulf Oil Corp., 268 F. Supp. 222 (N.D. Ga. 1967), thus applied Thibodaux to allow abstention in a suit for a tax refund involving an uncertain issue concerning the scope of the state tax. While that use of Thibodaux may be justifiable. DuVall v. Moore, 276 F. Supp. 689 (N.D. Iowa 1967), indicates a tendency to apply the same Thibodaux language so broadly that an uncertain issue concerning any subject of state regulation would be subject to abstention. The cases discussed in note 212 supra define Thibodaux abstention still more broadly by suggesting unclear state law as a sufficient condition for its exercise. And in some cases the limits the court places on Thibodaux are largely indiscernible. See, e.g., United Medical Labs, Inc. v. CBS, 256 F. Supp. 570, subsequently dismissed 258 F. Supp. 747 (D. Ore. 1966); Richey v. Sumoge, 257 F. Supp. 32 (D. Ore. 1966); Portland Paramount Corp. v. Twentieth Century-Fox Film Corp., 258 F. Supp. 962 (D. Ore. 1966), rev'd on merits sub nom Taylor v. Portland Paramount Corp., 363 F.2d 623 (9th Cir. 1967); David v. London Shirt Co., 259 F. Supp. 848 (D. Ore. 1966); B-W Acceptance Corp. v. Torgerson, 234 F. Supp. 214 (D. Mont. 1964).

${ }^{218}$ See text accompanying notes 175-76 supra.

219 There were two state issues in Thibodaux, one the unclear one concerning the city's condemnation power and the other an issue concerning the amount of compensa- 
when a federal constitutional issue was also at stake-the categorization would have no effect: If a case falls within the Pullman category, however that is defined, the abstention will not vary according to whether it also falls within the Thibodaux category, however that is defined. ${ }^{20}$ In that respect, "Thibodaux abstention" differs from the two categories of cases next to be discussed.

\section{Administrative Abstention}

"Administrative abstention" cases differ from Pullman cases in that neither the existence of unclear state law nor the presence of a federal constitutional question is necessary for abstention. Moreover, abstention is ordered in administrative cases to enable state courts to decide federal issues as well as state ones, and under the administrative abstention doctrine a case must pass through the state judicial system even if all its issues are clearly federal. Accordingly, administrative abstention does not merely postpone original federal jurisdiction but actually displaces it, ${ }^{221}$ removing entirely from the original

tion, to be decided if the condemnation were sustained. Justice Frankfurter said that the second issue, if reached, would be decided by the federal district court, and accordingly claimed that Thibodaux abstention "does not constitute abnegation of judicial duty. On the contrary, it is a wise and productive discharge of it. There is only postponement of decision for its best fruition." 360 U.S. at 29 . Even if he is correct that the compensation issue in Thibodaux itself would, if reached, return to the federal court, see note 220 infra, it is questionable whether there would usually be an issue in "Thibodaux abstention cases" to make abstention simply a postponement of jurisdiction. It would seem perfectly plausible that the only issue in the case would be the disputed one. In Mashuda, for example, the issue of damages had been litigated in a prior state proceeding. If abstention had been ordered on the unclear state issue, a return to federal court would not seem a possibility. Thus in at least some Thibodaux cases, state jurisdiction may replace federal jurisdiction, unlike Pullman abstention.

${ }^{220}$ There is one possible argument that the disposition of the categories does differ and if it were adopted, the categorization would sometimes be important. While the Court in Thibodaux indicated it would abstain only on the unclear state issue, leaving clear state issues for the federal forum, see note 219 supra, language in Pullman cases often implies, without explicit mention of the issue, that if abstention is ordered state issues generally will be left to state courts, with only federal issues reserved for original federal adjudication. See England v. Louisiana State Bd. of Medical Examiners, 375 U.S. 411 (1964). While a case can be made for either the Thibodaux or the England approach on this point, nothing in the two categories of cases would warrant a different solution for each of them. Presumably when the issue is explicitly addressed the Court will either leave all state issues to state tribunals when it abstains under either category, or else will in both categories leave only the unclear issue.

${ }^{221}$ The same can be true of at least some Thibodaux abstention cases. See note 219 supra. 
federal jurisdiction cases that fall within federal jurisdictional grants; $;^{222}$ a state court will dispose of all the issues in the case, subject to possible Supreme Court review, and whether or not such review is granted, res judicata will bar a party from having the federal district court decide the issue anew. ${ }^{23}$

The scope of administrative abstention, like Thibodaux abstention, is ambiguous largely because the reasoning that supports the abstention is not clear. The doctrine is defined primarily by reference to two cases: Burford v. Sun Oil Co. ${ }^{224}$ and Alabama PSC v. Southern Ry. ${ }^{225}$ In Burford, a diversity and federal question case, ${ }^{226}$ the Sun Oil Company sought to enjoin a Texas Railroad Commission order granting Burford a permit to drill certain wells in East Texas. The Supreme Court held that the suit should be dismissed. Writing for the Court, Justice Black emphasized that the order in question was "part of the general regulatory system devised for the conservation of oil and gas in Texas, an aspect of 'as thorny a problem as has challenged the ingenuity and wisdom of legislatures" "; that the "regulation of the industry by the state administrative agency" involved "basic problems of Texas policy"; and that several state law problems at issue were "of no general significance." 227 Perhaps most important, he noted that allowing a

${ }^{222}$ Largely for this reason, one commentator takes the position that this group of cases should not be termed "abstention" cases at all. Liebenthal, supra note 212 , at 159 .

${ }^{223}$ See England v. Louisiana State Bd. of Medical Examiners, 375 U.S. 411 , 415 n.5 (1964); Alabama PSC v. Southern Ry., 341 U.S. 341, 350 (1951) ("whatever rights appellee may have are to be pursued through the state courts"); Burford v. Sun Oil Co., 319 U.S. 315, 334 (1943) (". . . [I]f the state procedure is followed from the Commission to the State Supreme Court, ultimate review of the federal questions is fully preserved here"); C.A. WRIGHT, FEDERal Courts 200 (1970).

$22+319$ U.S. 315 (1943).

225341 U.S. 341 (1951).

${ }^{226}$ It is a point of some debate whether Burford should be deemed a federal question case as well as a diversity case. Compare Note, 56 HaRv. L. REv. 1162 (1943) with H. Hart \& H. Wechsler, The Federal Courts and the Federal System 872-73 (1953). See also Liebenthal, supra note 212 , at 161 . Hastings v. Selby Oil \& Gas Co., 319 U.S. 348 (1943). Federal question jurisdiction in Burford could technically have been based on a federal due process challenge to the order, which was challenged primarily on state grounds. The federal issue was not, however, prominent in the case, and the Supreme Court said nothing of avoiding federal constitutional adjudication in support of its decision to abstain.

${ }_{227} 319$ U.S. 318, 331-32. Justice Frankfurter dissented, saying that since state law was clear, the federal forum was duty-bound to exercise its jurisdiction. He deemed the federal forum necessary for the reason it generally is provided in diversity cases - the need for a neutral forum-and he contended that the Court's dismissal of jurisdiction contradicted the premises of diversity jurisdiction. 
federal forum to entertain the suit would lead to "conflicts in the interpretation of state law, dangerous to the success of state policies. . ."228 The standard the state applied for the spacing of oil wells was settled, ${ }^{229}$ but it left much room for variation in its application. Moreover, the state had taken pains to minimize judicial variation in applying the rules; it had concentrated review in the state district courts of a single county. ${ }^{230}$

In Alabama PSC $v$. Southern Ry., also founded on both federal question and diversity jurisdiction, the Southern Railway sought to enjoin a Public Service Commission order refusing to allow discontinuance of two passenger trains routed principally but not exclusively within Alabama. ${ }^{231}$ The railroad sought to challenge the order on both state and federal constitutional grounds as unjustified by "public necessity," "contrary to the evidence," violative of requirements for just compensation, a denial of due process and equal protection, and a burden upon interstate commerce. The district court, finding state law clear, ${ }^{232}$ enjoined the order on federal constitutional grounds. Not disputing the clarity of state law, the Supreme Court set aside the injunction and ordered dismissal on the basis that the regulation of intrastate railroad service was " "primarily the concern of the state" "; the problem was "essentially local"; and statutory appeal from a Commission order was "an integral part of the regulatory process." 233

The reasons for administrative abstention that one gleans from these two cases are remarkably similar despite the fact that Burford involved federal court decision of state law issues while Alabama PSC involved federal decision of federal issues. The first two Alabama PSC reasons-that the problem was local and primarily of state concern-seem makeweight. Because the allegation was that the order violated the Federal Consti-

228319 U.S. at 334.

229 There existed a standard for minimum spacing, subject to exceptions where necessary "to prevent waste or to prevent the confiscation of property." 319 U.S. at 322 .

230 Tex. Rev. Civ. Stat. art. 6049(c) § 8 (1962); see Texas Steel Co. v. Fort Worth \& D.C. Ry., 120 Tex. 597, 604, 40 S.W.2d 78, 82 (1931). Article 6049(c) $\$ 8$ is a rule of jurisdiction, not venue. Alpha Petroleum Co. v. Terrell, 122 Tex. 257, 265, 59

S.W.2d 364, 367 (1933).

${ }^{231}$ See 341 U.S. at 343.

23291 F. Supp. 980 (M.D. Ala. 1950).

233341 U.S. at $346-48$. 
tution, it is difficult to see the issue as of interest primarily to the state. Statements in Burford that the issues involved Texas policy and were of no general significance make more sense since that case involved difficult and substantial state issues. Problems remain, however, insofar as federal constitutional issues as well were involved in Burford. More seriously, such reasoning seems contrary to the bases of the diversity jurisdiction, which was one basis for federal jurisdiction in both cases.

Most rationales for allowing abstention in an administrative category of cases on terms other than those of the Pullman doctrine seem extremely unsatisfactory, because they squarely contradict the reasoning that limits Pullman. The difficulty is in finding any factor in administrative cases that makes abstention more appropriate than in cases dealt with under the Pullman doctrine; yet without finding such a factor, it is troublesome that abstention is ever ordered in these cases in the absence of unclear state law and the possibility of avoiding a federal constitutional issue. The rationale that comes closest to justifying separate treatment for administrative cases is suggested in Alabama PSC's statement that statutory appeal of a Commission order was "an integral part of the regulatory process," a rationale that seems to parallel Burford's emphasis on the Texas courts' responsibility for working with the Commission in regulating 'the oil industry. It is unclear exactly what aspect of the agency's order or its relation to the state judiciary made the judiciary be deemed "an integral part of the regulatory process" in either case. But it may be important that in both cases all review of the relevant commission orders was concentrated-in one county's courts in Burford and in one circuit court in Alabama PSC. ${ }^{234}$ Such concentration of judicial review would seem to enhance the case for deference to the state judicial machinery in two important ways. First, a single state court passing on agency action may truly develop a subject matter expertise that the federal courts could not match, and may participate more fully in formulating regulatory decisions than if the functions of judicial review were more scattered. Second, the concentration of judicial review suggests that the state may truly consider uniformity of deci-

${ }^{234}$ The statute concentrating review in Alabama PSC was AlA. CoDE tit. $48, \S 79$ (1958). 
sion on these matters to be unusually important. The argument for abstaining, at least in the absence of some pressing consideration in favor of federal decision of the particular issue and/or controversy involved, would stress that the state concern for uniformity of decision is a legitimate one, and is not aimed specifically against the exercise of federal jurisdiction (since state courts that would otherwise have jurisdiction are deprived of it as well). ${ }^{235}$

But even the state's commitment to uniformity and expertise would not necessitate abstention without regard to the clarity of state issues. At most it would seem that, in situations in which the state had evidenced such a commitment, a federal court deciding whether to abstain should be generous to state adjudication in determining whether or not a particular state issue was clear. The explanation may be, however, that the state tribunals' expertise lies less in their understanding of relevant state provisions than in their special knowledge of a factually complex administrative scheme. In Burford itself great variations in the application of a consistently stated standard were possible, rendering the results of individual cases uncertain although in one sense state law was clear. That rationale for a separate administrative category has the virtue of also providing a possible explanation for abstention obtaining for federal as well as state issues. While federal tribunals' legal determinations of federal issues are presumptively more reliable, conceivably a body especially equipped to analyze a complex factual pattern would better apply the federal rules.

While this explanation might possibly make a separate category of "administrative abstention" logically compatible with Pullman's limitations, the administrative abstention doctrine has not been limited, in its application by lower courts, to cases in which the state had concentrated review of an agency's determinations in a single court or group of courts, let alone to those in which the factual situation appeared especially complex and within the reviewing body's expertise. ${ }^{236}$ More-

${ }^{235}$ Indeed, Justice Frankfurter, dissenting in Burford, asserted that in its provision confining review to courts in Travis County, the Texas legislature had not intended to affect the jurisdiction of federal courts but only to displace the jurisdiction of state courts other than those in Travis County. 319 U.S. at 342-44. Compare Reagan v. Farmers' Loan \& Trust Co., 154 U.S. 362, 391-92 (1894).

${ }^{236}$ E.g., Atlantic Coast Line R.R. v. City of St. Petersburg, 242 F.2d 613 (5th Cir. 1957); Applegate v. Waterfront Comm'n, 129 F. Supp. 71 (S.D.N.Y. 1955). 
over, the lack of complexity in Alabama PSC may remove even that case from the suggested explanation.

While lower courts have not consistently adopted any one explanation or limitation for the administrative abstention doctrine, their rationales and limitations generally contradict the Pullman doctrine's premises. One obvious way of delimiting the administrative abstention doctrine, which some lower courts have adopted, is to find administrative abstention proper whenever a state administrative agency's order is at issue $e^{237}$ and-as is prerequisite to any type of abstention-an adequate state remedy is available to deal with the plaintiff's grievance. Another less precise approach would demarcate administrative abstention according to the degree to which the reviewing court will be required to dabble in the administrative scheme in performing its reviewing function, but without regard to the concentration of judicial review or any special expertise on the part of the state's reviewing court. It would call for administrative abstention if the factors that the reviewing court will have to consider are complex, and if they are within the

${ }^{237}$ The concurring Justices in Alabama PSC appear to have believed this to be the limiting principle for administrative abstention. 341 U.S. at 362. Accord, Note, Judicial Abstention from the Exercise of Federal Jurisdiction, 59 Colum. L. REv. 749, 760 (1959); Comment, 40 Calif. L. Rev. 300, 306-07 (1952). Professor Kenneth Culp Davis, however, disagrees. See $3 \mathrm{~K}$. Davis, Administrative Law Treatise § 23.18, at 382-84. See also Comment, 19 U. CHI. L. Rev. 361,367 n.41 (1952).

A rule that administrative abstention would come into play whenever a state administrative agency's order is at issue raises the difficulty of deciding how an "administrative agency" should be defined. Any reasons for requiring that state rather than federal judicial remedies be pursued for administrative decisions would seem to obtain as well when a single official was the decisionmaker. $C f$. Pennsylvania v. Williams, 294 U.S. 176 (1935).

Martin v. Creasy, 360 U.S. 219 (1959), could be deemed Supreme Court authority for the proposition that administrative abstention is proper for state court review of the decision of a single official. It is not absolutely clear, however, that Martin should be deemed an administrative abstention case. Liebenthal suggests it is in fact a Pullman case, see Liebenthal, supra note 212, at 165, though he recognizes that in so characterizing it he must deem the Supreme Court in error in dismissing it rather than retaining jurisdiction, as England, some years later, made clear was the correct Pullman procedure.

Martin does, however, bear characteristics of an administrative abstention case: Not only did the Supreme Court dismiss the case, but the case also involved a complex regulatory scheme. See 360 U.S. at 224-25. Moreover, review of actions to enjoin the head of an administrative department was concentrated in the courts of one county. See PA. R. Crv. P. $\S 1503$ (c). Martin was such an action, although subsequent to an abstention by the federal district court, that state court had already found it premature to decide the case prior to "viewers proceedings," see PA. Stat. AnN. tit. 36, $\S 670-301$ et seq. (1961), review of which was not concentrated. 
agency's expertise and beyond the ken of the federal court. ${ }^{238}$ The imprecision of that test may, allow it best to reconcile the case law; seeming deviants, which might include Alabama PSC, can be explained as misapplications of the standard rather than an alteration in the standard itself. Many commentators, however, have declined to be even that precise in delineating the administrative abstention requirements. Professor Wright recognizes "Burford-type abstention" as a separate category of abstention but never states precisely what will invoke it, noting only that its purpose is "to avoid interference with state activities." the Burford doctrine simply as a "doctrine that the federal court should relinquish jurisdiction where necessary to avoid needless conflict with the administration by a state of its own affairs."240 Likewise Mr. Liebenthal seems to adopt an "all the circumstances" approach. He suggests that Burford and Alabama $P S C$ "are merely examples of the traditional equity cases concerned primarily with the propriety of equitable relief in a given situation in which the Court places great emphasis on the factor of federal-state harmony"-that the doctrine of those cases "is no more than the doctrine which the Court had used before: No equity court will unnecessarily give extraordinary equitable relief, even though that court has jurisdiction to do so."241

${ }^{238}$ Language in Justice Frankfurter's dissenting opinion in Great Northern Life Ins. Co. v. Read, 322 U.S. 47, 60 (1944), concerning the scope of Burford suggests either such a rule or a rule limited to concentrated review. The case was not an abstention case. The Court had held that an Oklahoma statute consenting to suits to recover taxes restricted its consent to suits brought in state courts; construing the statute narrowly, the majority had adopted a rationale similar to the Burford reasoning. 322 U.S. at 54-55. Justice Frankfurter stated in dissent:

There is here an entire absence of the considerations that led to the decision in Burford v. Sun Oil Co., 319 U.S. 315. There it was deemed desirable, as a matter of discretion, that a federal equity court should step aside and leave a specialized system of state administration to function. Here the suit in a federal court would not supplant a specially adaptable state scheme of administration nor bring into play the expert knowledge of a state court regarding local conditions. The subject matter and the course of the litigation in the federal court would be precisely the same as in the state court. The case would merely be argued in a different building and before a different judge. Language restrictive of suit in a federal court is lacking, and intrinsic policy does not suggest restrictive interpretation to withdraw from a federal court questions of federal constitutional law.

Id. at 60 .

${ }^{239}$ C.A. Wright, Federal Courts 200 (1970).

${ }^{240}$ ALI STUDY, supra note 33, at 283.

${ }^{241}$ Supra note 212, at 163-64. 
Any administrative abstention doctrine broader than one related to a state's concentration of judicial review should be rejected as conflicting with Congress' jurisdictional scheme and with the limits upon Pullman abstention. But if a broader administrative abstention doctrine is to exist, as it unquestionably does today, it is important to Pullman abstention to know what the limits are because otherwise it may be unclear within which of the two categories a particular case falls. If a case satisfies both the Pullman requirements for abstention and the administrative ones, however those categories are defined, the case should presumably be treated as an administrative one; in cases falling within the administrative category, abstention is allowed more readily, and with respect to more issues, than in Pullman cases. ${ }^{242}$ It may not ever be desirable, because a case qualifies as "administrative," to refer it to the state judicial system for disposition on all the issues-or, indeed, to order any abstention at all. But if that disposition of administrative cases generally is deemed desirable or proper, the fact that a case also meets Pullman requirements does not make it less so. The presence of unclear state law obviously does not make abstention less desirable. Nor does the presence of a federal constitutional issue, under the precedents, make administrative abstention less proper; administrative abstention cases have frequently involved federal constitutional issues. ${ }^{243}$

While this treatment of a case that satisfies both Pullman and administrative requirements may seem rather elementary, it is not clear that courts have consistently so disposed of such cases. It is fairly typical for a court not to advert at all to which type of abstention is at issue or to entangle references to both types of abstention as though they were interchangeable. ${ }^{244}$

242 The Pullman, administrative, and Thibodaux abstention doctrines all state conditions for removing cases from federal jurisdiction which prima facie exists; the initial presumption in all of them is in favor of federal jurisdiction. Cf. note 265 infra \& accompanying text. When the Pullman and the administrative abstention conditions concur, therefore, it seems logical that a court should remove the case from the federal jurisdiction in accordance with the doctrine of administrative abstention, since that doctrine removes it more completely. But see Barrett v. Atlantic Richfield Co., 444 F.2d 38, 45 (5th Cir. 1971).

${ }^{243}$ In fact, some commentators have found it necessary to argue that the doctrine should not be limited to cases involving federal constitutional issues. Note, 59 Couvm. L. REv. 749, 762 (1959).

${ }^{244}$ See, e.g., Kaiser Steel Corp. v. W.S. Ranch Co., 391 U.S. 593 (1968). A concurring opinion treats Kaiser as an administrative abstention case, while the majority opinion never adverts to what type of abstention is at issue. Martin v. Creasy, 360 
Burford is a case that could be used to show that when the requirements of both types of abstention are met, administrative abstention is ordered, for Burford arguably satisfied the Pullman abstention requirements, ${ }^{245}$ and Pullman antedated Burford. ${ }^{246}$ Other cases, however, appear to contradict that rule and further discussion of why they are treated as Pullman rather than as administrative abstention cases is necessary to make the line between the two categories intelligible.

Pullman, ironically, is itself a case that under the abovedelineated factors for administrative abstention would seem to qualify for treatment as an administrative case. ${ }^{247}$ Clearly Pullman involved review of the order of an administrative agency-the Texas Railroad Commission. Moreover, review of that agency's orders was concentrated; indeed, it was limited to the same county's courts that review of the Burford orders was. ${ }^{248}$ Only if abstention were limited to suits involving factually complex situations would Pullman seem to fall without that doctrine, but on that test Alabama PSC might as well. ${ }^{249}$

The troublesome fact is that the Court has not explicitly addressed the issue of the line of demarcation between Pullman and administrative abstention. Because of the difference in disposition of the two categories of cases, the line can be cru-

U.S. 219 (1959), set off a debate as to the type of abstention involved which still continues. See notes 237 supra \& 246 infra. In McNeese v. Board of Educ., 373 U.S. 668 (1963), which was seen by Justice Harlan in dissent as an administrative abstention case, the Court did not specify which type of abstention was involved-an omission that has led to confusion concerning the possibility of abstention in civil rights cases. See notes 162-66 supra \& accompanying text.

${ }^{245}$ A key question is whether the federal constitutional issue was genuine. See note 226 supra.

${ }_{246}$ Martin v. Creasy, 360 U.S. 219 (1959), may also support that rule. Certainly Martin was treated, though without explanation by the Court, as an administrative case, for its disposition was dismissal. Liebenthal maintains, however, though his reasoning is not explicit, that Martin was a Pullman case and that the disposition by the Court was erroneous. Liebenthal, supra note 212, at 165. Even if Martin does satisfy the Pullman requirements, Liebenthal should have to show also that it does not satisfy the requirements for administrative abstention in order to prove the disposition inappropriate. The uncertainty whether Martin is an administrative case reflects confusion concerning what the requirements for administrative abstention are. See note 237 supra \& accompanying text.

${ }^{247}$ Pullman was decided prior to Burford. Burford, however, did have its precursors. See, e.g., Pennsylvania v. Williams, 294 U.S. 176 (1935).

${ }^{248}$ The statutes concentrating review in the two cases bear a marked resemblance. Compare Tex. Rev. Civ. Stat. art. 6453 (1926) (Pullman) with Tex. Rev. Civ. STAT. art. 6049(c), \& 8 (1935) (Burford).

${ }^{249}$ Another case that is troublesome from the standpoint of the line between Pullman and administrative abstention is Reetz v. Bozanich, 397 U.S. 82 (1970). The 
cial to parties who have a preference concerning the state or federal forum. Since so much can turn on whether a case is characterized as Pullman or administrative, it is strange to have no intelligible law on the subject. If it retains an administrative abstention category at all, the Court should hold that the line between it and Pullman abstention is defined by the limits placed on administrative abstention, since if a case qualifies as administrative, whether it satisfies Pullman requirements as well should be simply irrelevant. And if administrative abstention is retained, it is also important to the proper application of the Pulman doctrine that the Court isolate the factors that invoke the administrative doctrine and attend to their presence or absence in each case.

Currently it may be of little import to Pullman abstention what the limits of administrative abstention are and which category predominates when a case satisfies administrative and Pullman requirements, because there may be an exception to the administrative abstention doctrine for suits brought under the Civil Rights Act. As stated earlier, ${ }^{250}$ McNeese v.

issue in Reetz was the constitutionality, under state and federal law, of Alaska provisions limiting salmon fishing licenses to particular persons. The licenses were issued through a state administrative agency. That agency's regulations, as well as the authorizing statute, were attacked as unconstitutional. The plaintiffs had applied for and had been denied the fishing licenses they sought in 1968. They apparently did not request licenses under the 1969 regulations. See Bozanich v. Reetz, 297 F. Supp. 300, 304 (D. Alaska 1969). The fact that in the litigation they were not formally challenging the denial of licenses may justify the Court's failure to treat the case as administrative. If so, however, plaintiffs would be able strategically to manipulate the application of the abstention doctrines by the way they frame their suit. That would seem out of keeping with abstention's purposes, which are to protect interests other than the plaintiffs', and which seem unaffected by the difference between the form of the plaintiffs' suit in Reetz and the form the suit would have taken if the plaintiffs had applied for licenses in 1969. Cf. Wreiole v. Waterfront Comm'n, 132 F. Supp. 166 (S.D.N.Y. 1955). Although the plaintiffs in that case attacked a statute authorizing an administrative order rather than the administrative order itself, the Court did not allow that fact to prevent administrative abstention.

Moreover, if in Reetz it is the plaintiffs' failure to apply for licenses in 1969 that explains the Court's treatment of the case as a Pullman case rather than an administrative one, it is troublesome that the opinion of the Court does not reflect that fact. Instead the possibility of administrative abstention is not alluded to, and Pullman abstention seems simply to have been assumed as the issue. See also Lake Carriers' Ass'n v. MacMullen, 406 U.S. 498 (1972) (administrative abstention not contemplated).

Another case that was treated as a Pullman case but that might conceivably have qualified for administrative abstention, depending upon the scope given that doctrine, is Reid v. Board of Educ., 453 F.2d 238 (2d Cir. 1971), in which judicial review was not concentrated. $C f$. Chicago v. Fieldcrest Dairies, Inc., 316 U.S. 168 (1942).

${ }^{250}$ See notes 162-66 supra \& accompanying text. 
Board of Education ${ }^{251}$ probably should not be read to create an exception to Pullman abstention for civil rights cases. But it seemingly does create such an exception for administrative cases, an exception allowing the bypassing not only of state judicial remedies, as were involved in Burford and Alabama $P S C$, but also of remedies of the administrative agency itself. ${ }^{252}$ If such an exception to administrative abstention is accepted, it could encompass all cases currently admitted to the Pullman category. As long as a federal constitutional issue is requisite to Pullman abstention, it would seem that all cases satisfying current Pullman standards could be pursued under the civil rights exception, if they satisfied the criteria for administrative abstention as well. In that event, there would be no problem of overlap between the Pullman and administrative categories. The problem of overlap remains relevant, however, to the extent that doubt remains concerning the existence of the civil rights exception or its scope. ${ }^{253}$ Moreover, the problem would recur if the suggestion were adopted that Pullman abstention not be limited to cases containing a federal constitutional issue.

\section{The Dombrowski-Younger Line of CASES}

It is basic to Pullman abstention that the presumption is in favor of federal jurisdiction; it takes "special circumstances" - usually articulated as unclear state law and the possibility of

251373 U.S. 668 (1963).

252 See language quoted in note 163 supra.

${ }^{253}$ McNeese's holding is the chief authority for the exception. There is some problem even with that case as authority, for the Court announced as well a different and sufficient ground for its decision: that the administrative procedure that the state provided was an inadequate one. While that ground might limit McNeese, however, the case of Damico v. California, 389 U.S. 416 (1967), held that the limitation is unintended. Plaintiffs in Damico sued under the Civil Rights Act to challenge the constitutionality of certain welfare provisions. They brought suit in federal court without either first pursuing administrative remedies or challenging them as inadequate. The district court dismissed the complaint for failure to exhaust administrative remedies but the Supreme Court, without hearing argument, reversed per curiam, indicating that under McNeese exhaustion of administrative remedies is not required. Justice Harlan alone dissented, expressing a desire to limit McNeese to cases involving inadequate administrative remedies. Damico is of interest also because while a civil rights exception laid down by $M c N e e s e$ could conceivably be limited to racial matters, the Damico holding precludes such a narrowing of the exception.

While Damico would seem dispositive of the exhaustion problem, Justice White, writing for the Court, has recently claimed it is an open question whether McNeese states an invariable exception to administrative exhaustion. Gibson v. Berryhill, 411 U.S. 564, 575 (1973). (Two concurring Justices, however, stated it is an invariable exception. Id. at 581). Some lower courts, moreover, have declined to apply a 
avoiding a federal constitutional question-to justify referring state law issues to the states. ${ }^{254}$ There is, however, a category of cases falling within federal jurisdictional grants in which the presumption is in favor of state jurisdiction, and the federal plaintiff must show "special circumstances" to justify the exercise of federal jurisdiction. ${ }^{255}$ It is this group that will be referred to as the "Dombrowski-Younger" group of cases. It differs from the Pullman group also in that, as in administrative cases, a federal court decision staying its hand results in a state proceeding wherein federal issues are adjudicated along with state ones. ${ }^{256}$

A description of three of the leading cases in the "Dombrowski-Younger" category illustrates the difference. between

McNeese exception where the state remedy to be pursued is an adequate one. E.g., Eisen v. Eastman, 421 F.2d 560, 567-69 (2d Cir. 1969). In Eisen, Judge Friendly distinguished Damico on the ground that a terse elaboration of Damico in King v. Smith, 392 U.S. 309,312 n.4 (1968), indicated that administrative remedies need not be exhausted only where constitutionality was an issue and exhaustion would probably be futile.

${ }^{254}$ See, e.g., Baggett v. Bullitt, 377 U.S. 360, 375 (1964); Propper v. Clark, 337 U.S. 472,492 (1949).

${ }^{255}$ Dombrowski v. Pfister, 380 U.S. 479, 485 (1965). See also Douglas v. City of Jeannette, 319 U.S. 157, 163 (1943).

${ }^{256}$ Moreover this proceeding may be, and usually is, a state criminal prosecution, as it is most unlikely to be in Pullman abstention cases. See note 200 supra. It is not altogether clear, however, that the Dombrowski-Younger category is limited to suits involving state criminal prosecutions as distinct from state civil enforcement proceedings. See note 278 infra. It does seem that only enforcement proceedings by the state against the particular federal plaintiff will warrant the deference the DombrowskiYounger category affords. This limitation obviates the problem that a state declaratory remedy would almost always be adequate to prevent irreparable harm in the Dombrowski-Younger sense of that term, see text accompanying notes 266-68 infra, and thus, if it could invoke the Dombrowski-Younger change of presumption, could operate to displace almost entirely federal jurisdiction. See notes 264-76 infra \& accompanying text.

There is another important doctrine that is distinct from the Dombrowski-Younger or any other abstention doctrine, whereby a federal court may in its discretion defer to state declaratory or other proceedings involving the same issues as the federal action, whether the proceedings are between the same parties or not, by awaiting the outcome of the state proceedings before going forward with the federal suit. Amdur v. Lizars, 372 F.2d 103 (4th Cir. 1967); P. Beiersdorf \& Co. v. McGohey, 187 F.2d 14 (2d Cir. 1951); see H. Hart \& H. Wechsler, The Federal. Courts and THE FEDERAL SYSTEM 1057 (1953). That doctrine, which is frequently alluded to in cases along with one or more abstention doctrines, is supplementary to the abstention doctrines and may explain some cases that may otherwise seem difficult to justify in terms of the traditional abstention categories. E.g., Askew v. Hargrave, 401 U.S. 476 (1971); Kaiser Steel Corp. v. W.S. Ranch Co., 391 U.S. 593 (1968). It may be justifiable to allow deference to an ongoing state proceeding in the district judge's discretion without regard to whether traditional abstention requirements are met, not only because of the state's interests but also because such deference does not 
this group and Pullman cases. Douglas v. City of Jeannette ${ }^{257}$ was a suit to enjoin the city of Jeannette from prosecuting the plaintiffs for violating an ordinance prohibiting distribution of pamphlets without obtaining a license. The plaintiffs claimed the ordinance violated the first amendment when applied to Jehovah's Witnesses. The district court agreed and issued an injunction prohibiting enforcement of the ordinance against the plaintiffs or other Jehovah's Witnesses. In another case decided the same day as Douglas, ${ }^{258}$ the Supreme Court sustained the plaintiffs' position on the substantive ground, holding that the ordinance could not constitutionally be applied to religious solicitation. In Douglas, however, it reversed the judgment of the district court, holding it error to grant an injunction against prosecution under the invalid ordinance. The Court said the injunction was unnecessary since the plaintiffs could assert their federal constitutional claim in defending any criminal prosecution. ${ }^{259}$

In Dombrowski v. Pfister ${ }^{260}$ the plaintiffs sought declaratory relief and an injunction restraining various state officials from prosecuting them under a statute which they claimed violated the first amendment because it was overbroad. They also alleged that the threatened prosecutions would not be brought in good faith but instead would be brought with no hope of securing valid convictions, as part of a campaign to harass the plaintiffs. The district court had emulated the Supreme Court's Douglas holding and held that even if the plaintiffs' constitu-

impose on the parties as much as abstention often does, since it does not require initiation of any additional proceeding.

257319 U.S. 157 (1943).

${ }^{258}$ Murdock v. Pennsylvania, 319 U.S. 105 (1943).

${ }^{259}$ A narrow but possible explanation of Douglas is that an injunction was thought unnecessary because Murdock rendered it unlikely that the city would prosecute. Cf. Speight v. Slaton, 94 S. Ct. 1098 (1974). The Court's language in Douglas is broader than that narrow reading and suggests that in the absence of Murdock the Douglas holding would be the same. In Dombrowski, while the Court distinguished Douglas at one point on the ground that Pennsylvania -courts and prosecutors could be expected to follow Murdock, 380 U.S. at 162, it dealt also with the other reasoning Douglas suggested.

Except for the Murdock holding, the plaintiffs in Douglas had shown a likelihood that the ordinance would be enforced against them. They had earlier been arrested and prosecuted for distributing pamphlets similar to those they currently desired to distribute, and state officials had threatened to continue so to prosecute them. See Zwickler v. Koota, 389 U.S. 241 (1967); $c f$. Younger v. Harris, 401 U.S. 37, 41-42 (1971).

${ }^{260} 380$ U.S. 479 (1965). 
tional allegations had merit, an injunction against state prosecution was not warranted.

The Supreme Court disagreed, finding here special circumstances justifying the exercise of federal jurisdiction: Defense of the state criminal prosecution in this instance was not adequate to protect the plaintiffs' constitutional rights. While the Court did not clearly set forth the circumstances that would impel the exercise of federal jurisdiction, it was relevant that bad faith was alleged. It was also relevant that the challenged statute regulated freedom of expression and was attacked on grounds of overbreadth. A statute containing that vice is unlikely to be cured, according to the Court, ${ }^{261}$ in a single state proceeding. ${ }^{262}$ Yet plaintiffs in such cases should not have to await a series of prosecutions, for while they are pending, the threat of prosecution may substantially chill the exercise of first amendment rights.

Finally, in Younger $v$. Harris ${ }^{263}$ the plaintiff sought to enjoin the Los Angeles district attorney from prosecuting him for violating the California Criminal Syndicalism Act. He claimed "that the prosecution and even the presence of the Act inhibited him in the exercise of his rights of free speech and press." 264 The district court held in his favor, finding the Act void for vagueness and overbreadth. The Supreme Court reversed, saying that as in Douglas the state criminal prosecution was an adequate forum for raising the constitutional issue.

While federal jurisdiction was exercised in Dombrowksi and declined in Douglas and Younger, in all three cases the Court started from the premise that the federal courts should defer in favor of state jurisdiction if the contemplated state proceeding was adequate to protect the plaintiffs' rights. It is that premise, which separates these from Pullman cases, that is of primary interest here, and not the much-discussed issue of which cases within the Dombrowski-Younger category warrant the exercise of federal jurisdiction and which do not. Why is the presumption against the exercise of federal jurisdiction

${ }^{261}$ But see the state courts' construction of the ordinances in Shuttlesworth 'v. Birmingham, 394 U.S. 147 (1969); Poulos v. New Hampshire, 345 U.S. 395 (1953); and Cox v. New Hampshire, 312 U.S. 569, 575-76 (1941).

262380 U.S. at 486. See also Baggett v. Bullitt, 377 U.S. 360, 378-79 (1964).

263401 U.S. 37 (1971).

264401 U.S. at 39. 
in Dombrowski-Younger cases, requiring the plaintiff to show the necessity of federal jurisdiction on the facts of his particular case, when those cases like Pullman cases fall within congressional jurisdictional grants? ${ }^{265}$

The explanation the Court has most prominently given for not exercising jurisdiction in Dombrowski-Younger cases is the plaintiffs' failure to satisfy the requirement of irreparable harm. The Court has recalled the traditional rule of equity that irreparable harm must be shown for an injunction to issue and reasoned that that prerequisite to injunctive relief ${ }^{266}$ is not satisfied if the state proceeding provides an adequate forum for litigating the constitutional issue. ${ }^{267}$

The irreparable harm requirement does not, however, adequately explain why Dombrowski-Younger cases differ from Pullman cases, which also typically involve injunctive relief. In Pullman cases, however, the Court follows its usual equity practice of applying the irreparable harm requirement and the rule of equity that no injunction should issue if there is an adequate remedy at law, by looking to whether available remedies on the law side of the federal court afford the plaintiff sufficient protection. ${ }^{268}$ Because of its "duty" to "give due respect to a suitor's choice of a federal forum for the hearing and decision

${ }^{265}$ Like Pullman cases, these cases are typically brought under the general federal question jurisdiction, 28 U.S.C. $\$ 1331$ (1970); the Civil Rights Act, id. § 1343 (1970); the Declaratory Judgment Act, id. $\$ 2201$ (1970); and/or the diversity jurisdiction, id. $\S 1332$ (1970). In some of the cases there is an issue of "justiciability" as well. E.g., Boyle v. Landry, 401 U.S. 77 (1971); Younger v. Harris, 401 U.S. 37, 41-42 (1971). Of course, where the case is deemed nonjusticiable federal jurisdiction will not be exercised for that reason. What is significant is the need specially to justify the exercise of federal jurisdiction in these cases when the standing, ripeness, and other case-or-controversy requirements are met.

${ }^{266}$ Though traditionally it is a prerequisite to injunctive relief, the same limitation applies in these cases when declaratory relief is sought, at least when a state prosecution is pending. Samuels v. Mackell, 401 U.S. 66 (1971). Zwickler v. Koota, 389 U.S. 241 (1967), indicated that is not the case when no state prosecution is pending, but the Samuels reasoning suggested that Zwickler would no longer be followed in that respect. But see Perez v. Ledesma, 401 U.S. 82, 103-30 (1971) (Brennan, J., concurring in part and dissenting in part). The recent case of Steffel v. Thompson, 94 S. Ct. 1209 (1974), appears, however, to limit Samuels to cases involving pending state prosecutions. But cf. notes 322-23 infra.

${ }^{267}$ See Younger v. Harris, 401 U.S. 37, 43-49, 53-54 (1971); Dombrowski v. Pfister, 380 U.S. 479, 484-89 (1965); Douglas v. City of Jeannette, 319 U.S. 157, 162-64 (1943).

${ }^{268}$ See DiGiovanni v. Camden Fire Ins. Ass'n, 296 U.S. 64, 69 (1935); McConihay v. Wright, 121 U.S. 201 (1887). 
of his federal constitutional claims,"269 the Court does not take into account, in determining whether the equity requirements are met, the existence of state proceedings that could provide adequate relief.

The irreparable harm requirement cannot then explain the difference in presumption between Dombrowski-Younger and Pullman cases. For different irreparable harm requirements are imposed in the two classes of cases. Explanation remains necessary for why in Dombrowski-Younger cases the question asked is whether given the existence of the state forum ${ }^{270}$ as a possible forum, irreparable harm would result from a failure to exercise federal jurisdiction, while in Pullman cases the issue is whether irreparable harm supports injunctive relief and not whether it supports a federal forum.

The most likely explanation for the Court's differing approach delineates the Dombrowski-Younger category as cases involving attempts to enjoin state criminal proceedings and then invokes, in addition to federal-state comity; a traditional equitable doctrine ${ }^{271}$ against enjoining criminal proceed-

${ }^{269}$ Zwickler v. Koota, 389 U.S. 241, 248 (1967). Justice Brennan goes on to say for the Court:

Plainly, escape from that duty is not permissible merely because state courts also have the solemn responsibility, equally with the federal courts, ". . . to guard, enforce, and protect every right granted or secured by the Constitution of the United States. . ., Robb v. Connolly, 111 U.S. 624, 637. "We yet like to believe that wherever the Federal courts sit, human rights under the Federal Constitution are always a proper subject for adjudication, and that we have not the right to decline the exercise of that jurisdiction simply because the rights asserted may be adjudicated in some other forum". Stapleton v. Mitchell, 60 F. Supp. 51, 55; see McNeese v. Board of Education, 373 U.S. at 674, n.6. Cf. Cohens v. Virginia, 6 Wheat. 264, 404.

Id. Those statements are directly contradictory, however, to the practice in the Dombrowski-Younger group of cases where "adjudication of constitutional defenses in the course of a criminal prosecution" is considered "normal," Dombrowski v. Pfister, 380 U.S. at 485; where it takes a showing that being left to the state remedy will result in irreparable injury before a suitor's choice of the federal forum will be respected; and where the state forum will not be deemed inadequate simply on grounds of federal-court superiority in deciding questions of federal law, see 380 U.S. at 484 -the view that presumably lies at the basis of Congress' grant of federal question jurisdiction, and of the Court's insistence in Pullman cases that the parties may reserve federal questions for the federal forum.

${ }^{270}$ The state forum will usually, perhaps invariably, be a criminal trial court. See note 256 supra \& note 278 infra. But cf. note 323 infra.

${ }^{271}$ The rule that equity will not interfere with criminal prosecutions does have deep roots. The Supreme Court first expounded upon it in In re Sawyer, 124 U.S. 200 (1888), pointing out that well before the Declaration of Independence it was settled in England that courts of chancery lacked power to stay criminal proceedings 
ings. ${ }^{272}$ Language in Douglas supports both elements of this explanation:

... Congress, by its legislation, has adopted the policy, with certain well defined statutory exceptions, of leaving generally to the State courts the trial of criminal cases arising under state laws, subject to review by this Court of any federal questions involved. Hence, courts of equity in the exercise of their discretionary powers should conform to this policy by refusing to interfere with or embarrass threatened proceedings in state courts save in those exceptional cases which call for the interposition of a court of equity to prevent irreparable injury which is clear and imminent; and equitable remedies infringing this independence of the states-though they might otherwise be given-should be withheld if sought on slight or inconsequential grounds. ...

It is a familiar rule that courts of equity do not ordinarily restrain criminal prosecutions. . . . ${ }^{273}$

The Court's reasons for shifting the presumption in that category of cases do, however, leave something to be desired. Immediately preceding the above-quoted language, the Court

and that state courts had adhered to that limitation in interpreting the powers of their respective court systems.

${ }^{272}$ It is not absolutely clear that this is the explanation for the differing DombrowskiYounger and Pullman approaches to the exercise of federal jurisdiction, however, for it is not settled whether the Dombrowski-Younger category is limited to interference with criminal enforcement proceedings. See note 278 infra.

273319 U.S. at 163. Further language suggests that the impetus against exercise of federal jurisdiction comes largely from a reluctance to interfere with state criminal processes:

Notwithstanding the authority of the district court, as a federal court, to hear and dispose of the case, petitioners are entitled to the relief prayed only if they establish a cause of action in equity. Want of equity jurisdiction, while not going to the power of the court to decide the cause, . . . may nevertheless, in the discretion of the court, be objected to on its own motion. ... Especially should it do so where its powers are invoked to interfere by injunction with threatened criminal prosecutions in a state court.

319 U.S. at 162.

Language throughout Dombrowski and Younger also indicates that the Dombrowski-Younger analysis is limited to cases in which a plaintiff attempts to interfere with state criminal prosecutions, as does the language in other cases as well. E.g., Samuels v. Mackell, 401 U.S. 66, 68, 69, 71, 72, \& 73 (1971); Meredith v. Winter Haven, 320 U.S. 228, 235 (1943). And support is found for a traditional equitable doctrine against interfering with state criminal proceedings in Fitts v. McGhee, 172 U.S. 516, 531-32 (1899), and In re Sawyer, 124 U.S. 200, $210-11$ (1888). But of. Parker v. Brown, 317 U.S. 341, 349-50 (1943); Packard v. Banton, 264 U.S. 140, 143 (1924). 
said, "The power reserved to the states under the Constitution to provide for the determination of controversies in their courts may be restricted by federal district courts only in obedience to Congressional legislation in conformity to the judiciary Article of the Constitution." 274 Yet congressional legislation rather clearly places the cases in question within the federal jurisdiction. The Court's reference to a congressionally adopted policy of leaving criminal cases to the states is apparently an attempt to circumvent that difficulty; its language "Congress, by its legislation, has adopted the policy" may suggest the cases are not in fact in the federal sphere. The Court does not, however, inform us what legislation it has in mind. ${ }^{275}$ Moreover, it becomes clear that the Court is not referring to a legislative directive, but simply a policy the Court derives from congressional laws generally, when it goes on to say that federal courts should accordingly "in the exercise of their discretionary powers" decline to interfere with state criminal proceedings except when such interference is absolutely necessary to prevent irreparable harm. One wonders how such an uncodified congressional policy, admittedly not binding on the courts, can outweigh and displace the explicit congressional grants of jurisdiction contained in the general federal question statute and the Civil Rights Acts. ${ }^{276}$

But even if one were to accept a tradition of noninterference with state criminal proceedings as sufficient explanation for the differing Dombrowski-Younger and Pullman approaches to the exercise of federal jurisdiction, there would remain a

274319 U.S. at 162-63. In In re Sawyer, 124 U.S. 200 (1888), the Court quite properly noted that the traditional bounds of equity courts' jurisdiction, which it was describing, were controlling only "unless enlarged by express statute." Id. at 210.

275 The legislation most suggestive of the kind of congressional policy the Court refers to is congressional legislation permitting removal much more broadly in civil cases in state courts involving federal questions than in similar criminal cases.

${ }^{276} \mathrm{Cf}$. text accompanying notes $40-45$ and $65-71$. One could argue instead that the presumption in favor of state fora in these cases derives from the policy behind the federal anti-injunction statute, 28 U.S.C. $\$ 2283$ (1970), which forbids injunctions against state proceedings except in certain circumstances. Justice Black explained the policy this way in Younger v. Harris, 401 U.S. 37, 43 (1971). Such an explanation of the deference paid state courts in this class of cases does not, however, advance the inquiry, since the Anti-Injunction Act does not apply to these cases. At the time of the Younger decision it was an open issue whether cases arising under the Civil Rights Acts, as all the cases in question do, see text accompanying note 164 supra, are excepted from $\$ 2283$ or not; the Court in Younger declined to decide the issue. $40 \mathrm{I}$ U.S. at 54. It is now settled, however, that such an exception does exist. Mitchum v. Foster, 407 U.S. 225 (1972). And it has long been settled that the anti-injunction 
difficulty in knowing which cases to treat as Dombrowski-Younger cases, with the attendant presumption in favor of the state forum, and which instead to subject only to Pullman analysis. The difficulty in knowing how to treat a particular case is solely in the demarcation of the Dombrowski-Younger category, which changes the usual presumption concerning the exercise of federal jurisdiction in cases within a jurisdictional grant. Once it is known which cases warrant the application of the Dombrowski-Younger presumption, the interaction of that doctrine with the Pullman abstention doctrine seems clear. If the facts of a given case place it within the Dombrowski-Younger category, and if application of that category's rules suggests the state forum is proper, then a Pullman analysis becomes superfluous; the state forum will decide all issues in the case regardless of whether the case contains an unclear question of state law whose resolution might avoid a federal constitutional question. Like the administrative abstention category, then, the Dombrowski-Younger category can remove an other-

statute applies only against state proceedings that are pending at the time the injunction is sought, see Dombrowski v. Pfister, 380 U.S. 479, 484 n.2 (1965); Ex parte Young, 209 U.S. 123, 161-62 (1908), a rule that excludes some of the cases in the Dombrowski-Younger category from the statutory prohibition, including Dombrowski itself. There is another respect as well in which the Dombrowski-Younger category differs in scope from the anti-injunction statute: The statute applies to all pending state civil and criminal proceedings that are not excepted, whereas the DombrowskiYounger presumption may be limited to criminal proceedings, see text accompanying notes 271-76 supra, and at any rate does not cover more than state enforcement proceedings, see notes 256 supra \& 278 infra.

It is clear then that it, is not the anti-injunction statute itself that requires the shift in presumption in these cases. It seems strange, then, to assume that the policy behind the act could extend it to cases excepted from its reach. Nonetheless, that is the approach of Younger, in which the Court avoided deciding whether the act did apply by holding that the same result concerning the availability of an injunction would obtain whether or not it did; in either event, the federal court would exercise jurisdiction upon a showing of bad faith or harassment, which was deemed to satisfy the irreparable harm requirement, but not otherwise.

Even accepting that the same rule will obtain in cases within the statutory prohibition and those within exceptions, however, "the policy of the act" does not explain the shift of presumption in Dombrowski-Younger cases without identification of what that policy is. Nor can one know how far beyond the statute's terms the policy will apply without identifying it. In Younger, Justice Black admitted that "the precise reasons for this long-standing public policy against federal court interference have never been specifically identified," but he said the "primary sources" are, first, "the basic doctrine of equity jurisprudence that courts of equity should not act, and particularly should not act to restrain a criminal prosecution, when the moving party has an adequate remedy at law and will not suffer irreparable injury if denied equitable relief" (see note 271 supra) and second, "the notion of 'comity', that is, a proper respect for state functions," a doctrine which Justice Black refers to as "Our Federalism." 401 U.S. at 43-44. 
wise appropriate case from Pullman treatment. If, on the other hand, the case is within the Dombrowski-Younger category but is one in which the exercise of federal jurisdiction is deemed proper, then Pullman analysis as well must be undertaken. The case will remain wholly within the federal forum if it does not contain an unclear issue of state law whose resolution might avoid a federal constitutional question. If it does contain such an issue, however, Pullman abstention under the England procedures is proper and the parties retain the right to return to the federal court for adjudication of the federal issues. ${ }^{277}$

Assuming that the Dombrowski-Younger category is accurately described as "cases where the plaintiff seeks to interfere

277 Professors Bator, Shapiro, Mishkin, and Wechsler in H. HART \& H. WECHSLER, supra note 8 , at 1044 , have suggested that a case that survives Dombrowski-Younger analysis but is ultimately referred to state court as a result of Pullman analysis is "a merely theoretical possibility." It does seem perfectly possible, however, that a case that under Younger and Dombrowski is deserving of a federal forum because the federal plaintiff would suffer irreparable harm if limited to the state enforcement proceedings might also contain an unclear issue of state law whose resolution might avoid a federal constitutional question. Such a case seems unlikely only if it is deemed essential, in order to meet the Dombrowski-Younger irreparable harm requirement, that the case be one where the disputed issue does not appear capable of resolution in one state proceeding. For courts will not abstain under Pullman unless it appears that a single state proceeding can dispose of the state issue. See note 166 supra. But even if this were so, Pullman abstention might in a given case be proper on a different issue than the one that, if left to the state enforcement proceeding, would cause the litigants irreparable harm. Moreover, it is not clear whether it is essential to the exercise of federal jurisdiction in a Dombrowski-Younger case that the case be one where the issue the federal plaintiff raises could not be settled in a single state proceeding. If a federal plaintiff alleges bad faith or harassment, that may itself be sufficient to impel the exercise of federal jurisdiction. Language in Younger is ambiguous on the point. 401 U.S. at 49,53 , \& 54 . It could be read either as requiring only bad faith or harassment, or as requiring as well that the challenge be to a vague and/or overbroad statute, with which most Dombrowski-Younger cases are concerned, see Maraist, Federal Injunctive Relief Against State Court Proceedings: The Significance of Dombrowski, 48 Texas L. Rev. 535, 580-81 (1970), and where it is deemed that the defendant cannot adequately protect his federal rights by defending a single proceeding.

In Dombrowski in fact, after holding that the irreparable harm requirement for the exercise of federal jurisdiction was satisfied, the Court went on to discuss the propriety of Pullman abstention, 380 U.S. at 489-92. And the Supreme Court seems to have first analyzed AFL v. Watson, 327 U.S. 582 (1946), as a Dombrowski-Younger case and, having found that the irreparable harm requirement was met, 327 U.S. at 593-95, then held that Pullman abstention was nevertheless proper. (The only doubt concerning this categorization of AFL v. Watson comes from the Court's statement in the midst of its apparent Dombrowski-Younger analysis that it could look to the law side only of the federal courts in deciding whether alternative remedies are adequate. 327 U.S. at 594. In other respects, however, its analysis appears to be a Dombrowski-Younger one.) In Harrison v. NAACP, 360 U.S. 167 (1959), moreover, a three-judge court, NAACP v. Patty, 159 F. Supp. 503, 521 (E.D. Va. 1958), found sufficient irreparable harm to overcome Dombrowski-Younger requirements, but the Supreme Court deemed abstention necessary on the basis of Pullman analysis. 
with a state criminal prosecution," 278 the question remains what will be considered an attempt to interfere with a state criminal prosecution. It is settled that, at least when a state criminal proceeding is pending when the federal plaintiff files suit, ${ }^{279}$ an attempt to interfere by declaratory relief will be treated as the equivalent of an attempt to enjoin. But cases provide little guidance concerning which suits constitute attempts to interfere with criminal prosecutions. That category is not limited to situations in which criminal prosecutions are pending, for none was pending in Dombrowski, and despite the exercise of federal jurisdiction in the case it is a "DombrowskiYounger" suit in the sense that the Court required special circumstances to support the exercise of federal jurisdiction. ${ }^{280}$ Conceivably all cases in which a plaintiff phrased his aim in his pleadings as enjoining a state prosecution would be Dombrowski-Younger cases, whereas if he said he sought to enjoin

${ }^{278}$ The Dombrowski-Younger category may not, however, be limited to cases threatening interference with criminal enforcement proceedings. The decided Supreme Court cases do involve criminal proceedings, but it is an open issue, which has been adverted to by a number of Justices, whether civil enforcement proceedings should be included. Chief Justice Burger and Justices White and Blackmun seem to have taken the position that no line should be drawn between civil and criminal proceedings. Lynch v. Household Finance Corp., 405 U.S. 538, 561 (1972) (dissenting opinion). See also Mitchum v. Foster, 407 U.S. 225, 244 (1972) (concurring opinion). In his separate concurring statement in Younger v. Harris, Justice Stewart, joined by Justice Harlan, noted that the Court did "not deal with the considerations that should govern a federal court when it is asked to intervene in state civil proceedings, where, for various reasons, the balance might be struck differently" than in cases involving state criminal prosecutions. 401 U.S. at 55. At the same time, however, Justice Stewart indicated that he found major differences between criminal and civil proceedings. 401 U.S. at 55 n.2. In Gibson v. Berryhill, 411 U.S. 564, 575 (1973), the opinion for the Court, authored by Justice White, stated that it was still an open question whether the Younger v. Harris rules applied in state civil proceedings. At another point in the opinion, however, it stated that only three "established principles" would "under appropriate circumstances, restrain a federal court from issuing ... injunctions" against state court proceedings: the requirement of exhaustion of administrative remedies, Pullman abstention, and "the basic principle of federalism . . . that a federal court may not enjoin a pending state criminal proceeding in the absence of special circumstances ...." 411 U.S. at 573-74 (emphasis added). See also Mitchum v. Foster, 407 U.S. 225, 230, 237 (1972); Allee v. Medrano, 94 S. Ct. 2191, 2201 (1974); note 323 infra. In Speight v. Slaton, 356 F. Supp. 1101 (N.D. Ga. 1973), a three-judge district court declined under Younger to intervene in a pending state civil enforcement proceeding. On appeal the Supreme Court vacated the decision on other grounds. 94 S. Ct. 1098 (1974). See text accompanying notes 323-27 infra. The Court has since noted probable jurisdiction in a case that should resolve the issue. MTM, Inc. v. Baxley, 94 S. Ct. 1559 (1974).

${ }^{279}$ See note 266 supra.

${ }^{280}$ One factor relevant to whether federal jurisdiction will be exercised in a case that does fall within the Dombrowski-Younger category is whether the proceeding sought to be enjoined is pending. It once appeared that this factor governed as well whether 
operation of a statute, albeit a criminal one, Pullman analysis alone would apply. Such a rule would be extremely nonfunctional; no purpose behind either the Dombrowski-Younger or the Pullman doctrines is fulfilled by allowing a plaintiff through his pleading so to affect the choice of forum. And the cases show that the plaintiff's pleading is not determinative. ${ }^{281}$ Moreover the cases show the determinative question is not simply whether the statute the plaintiff attacks carries criminal penalties. That line might be justified simply on the theory that the basis for the presumption in favor of state jurisdiction is a desire to allow states to control their own criminal processes

the federal anti-injunction statute, 28 U.S.C. $\S 2283$ (1970), would apply to these cases since it covers only pending proceedings, see Dombrowski v. Pfister, 380 U.S. 479, 484 n.2 (1965); Ex parte Young, 209 U.S. 123, 161-62 (1908), but now it is settled that civil rights actions are within the "expressly authorized" exception to the congressional prohibition, Mitchum v. Foster, 407 U.S. 225 (1972), so the anti-injunction statute would seem in any event ineffective in the suits in question. But of. note 276 supra.

Since Dombrowski itself did not involve a pending state prosecution, it is clear that the line between pending and non-pending prosecutions does not demarcate the Dombrowski-Younger category. But of. Perez v. Ledesma, 401 U.S. 52, 120-21 (1971) (Brennan, J., concurring in part and dissenting in part). That line may be relevant, however, in deciding how to dispose of cases within the category. Douglas involved threatened and pending prosecutions, while Younger involved principally a pending one. In Younger the Court held the irreparable harm requirement would usually not be satisfied in an attempt to secure federal intervention in state criminal proceedings absent a showing of bad faith and harassment. (The Court said, 401 U.S. at 53, there might be other unusual circumstances that could show irreparable harm, including perhaps that the challenged prosecution "is only one of a series of repeated prosecutions to which [the plaintiff] . . . will be subjected," id. at 49 , but it did not detail them.) That rule for when the irreparable harm requirement is satisfied seems narrower than Dombrowski's rule. The difference is explainable on the ground that Younger involved pending proceedings while Dombrowski did not; there is language in Younger that would support that explanation. 401 U.S. at 41 ("We express no view about the circumstances under which federal courts may act when there is no prosecution pending in state courts at the time the federal proceeding is begun."); $i d$. at 45, 49 (references to "pending" proceedings). See also Perez v. Ledesma, 401 U.S. 82, 103-30 (1971) (Brennan, J., concurring in part and dissenting in part). Other language, however, would indicate that Younger cuts back on Dombrowski for non-pending cases as well. 401 U.S. at 45-53 (reference to "threatened prosecutions" and use as examples of cases involving non-pending prosecutions).

281 In both Pullman and Dombrowski-Younger cases the complaint typically prays for an injunction and/or declaratory relief against enforcement of the challenged state enactment. In Pullman and Harrison v. NAACP, 360 U.S. 167 (1959), for example, both of which were treated as Pullman and not Dombrowski-Younger cases, the plaintiffs sought respectively "to restrain the enforcement of a certain order made by the Commission ... ", Pullman Co. v. Railroad Commission, 33 F. Supp. 675, 676 (W.D. Tex. 1940); and "to secure a declaratory judgment and an injunction restraining and enjoining the defendants from enforcing or executing [the statute at issue]," NAACP v. Patty, 159 F. Supp. 503, 506 (E.D. Va. 1958). See also 360 U.S. at 169. The prayers for relief in Douglas and Dombrowski appear similar. In Douglas the 
and that the presumption must operate whenever a plaintiff seeks to enjoin the operation of a statute with criminal penalties. Case holdings belie the explanation; not all cases in which plaintiffs attack a statute with criminal penalties are treated as Dombrowski-Younger cases; some are subjected only to Pullman analysis. ${ }^{282}$

A more functional line of demarcation for the DombrowskiYounger category would focus on whether a criminal proceeding brought under the statute challenged was either pending or imminent. If it was neither, and there was nonetheless a case or controversy, Dombrowski-Younger treatment would not be proper. The rationale would be that though defense of a criminal prosecution might be adequate to protect the plaintiff, if no such proceeding seemed imminent it would not seem likely that the plaintiff would soon have that forum available. ${ }^{283}$ This line too has difficulties. The most obvious are the difficulties in deciding how imminent should be considered "imminent" and how imminence should be shown. ${ }^{284}$ Need

plaintiffs sought "to enjoin the defendant city of Jeannette and its Mayor from enforcing against them . . a certain ordinance of that city . . . Douglas v. City of Jeannette, 130 F.2d 652, 653 (3d Cir. 1942). In Dombrowski the plaintiff asked, inter alia, "that a permanent injunction issue ${ }^{*} * *$ restraining the defendants, their agents and attorneys from the enforcement, operation or execution of [the statutes in question] . . . ." ' Dombrowski v. Pfister, 227 F. Supp. 556, 558 (E.D. La. 1964).

In Zwickler v. Koota, 389 U.S. 241 (1967), so far as appears from the reports, the prayer for relief did explicitly ask that the defendant be restrained from "prosecuting" the plaintiff. 261 F. Supp. 985, 988 (E.D.N.Y. 1966). It is not clear whether it is a Dombrowski-Younger or solely a Pullman case. See note 292 infra. But in any event the phrasing of the complaint is not a factor in that determination.

Nor can the two categories of cases be separated according to the identity of the defendants sought to be enjoined. Law enforcement and prosecuting officials have been defendants in such Pullman cases as Harrison and Pullman itself, as well as in Dombrowski.

${ }^{282}$ For cases involving statutes bearing criminal penalties, yet subjected only to Pullman and not to Dombrowski-Younger analysis, see England v. Louisiana State Bd. of Medical Examiners, 375 U.S. 411 (1964); Harrison v. NAACP, 360 U.S. 167 (1959); cf. Lake Carriers' Ass'n v. MacMullan, 406 U.S. 498 (1972); Chicago v. Atchison, Topeka \& Santa Fe Ry., 357 U.S. 77 (1958).

It is noteworthy that the statute carrying criminal penalties in each instance could be characterized as part of a regulatory program rather than an ordinary criminal statute. On the basis of current case law, that distinction, though it is not a very precise one, could be said to separate the Pullman and Dombrowski-Younger categories.

283 Professors Bator, Mishkin, Shapiro and Wechsler in H. HART \& H. WECHSLER, supra note 8 at 1044, seem to assume that this is the line setting off the DombrowskiYounger category.

${ }^{284}$ Douglas v. City of Jeannette, 319 U.S. 157 (1943), indicated DombrowskiYounger analysis should be used when the plaintiffs are "threatened" with prosecution, at least when they have earlier actually been prosecuted for engaging in similar 
state officials have threatened proceedings against the plaintiff prior to the institution of the federal suit, or is it sufficient if in their answer they express an intent to institute such proceedings promptly? The latter approach would allow the state, at the pleading stage, to control whether a case would get Dombrowski rather than Pullman treatment, provided the plaintiff had violated the statute he challenged prior to his federal suit. That result might not be dysfunctional, however, if when a plaintiff challenges a state criminal enactment the only reason for not presuming in favor of state fora when no proceedings against him are pending or imminent is that he should not have to forego the federal forum without an affirmative showing that the state will provide an alternative. ${ }^{285}$

In some situations the suggested categorization may be the equivalent of a rule that any case in which the plaintiff attacks a statute carrying criminal penalties should be analyzed in the Dombrowski-Younger manner, for a plaintiff will often be unable to satisfy "case or controversy" requirements unless state enforcement proceedings are either pending or imminent. If the plaintiff has engaged in the conduct the state makes criminal, and no prosecution is even imminent, a challenge to the criminal statute is not likely to satisfy those requirements $^{286}$ unless the criminal conduct is conduct he wishes to continue to engage in. If he does wish to continue, however, he may well be deemed in need of a present adjudication of the validity of the state statute ${ }^{287}$ - a need that could satisfy justiciability requirements and that would not appear satisfied by an ability to defend a prosecution in the absence of the imminence of any such prosecution. Similarly when the plaintiff's attack on the validity of a statute that he has not yet violated is justiciable, ${ }^{288}$ he needs a forum in which to test the

conduct. Cf. note $292 \&$ text accompanying notes $319-22$ infra. AFL v. Watson, 327 U.S. 582, 588 (1946), applied Dombrowski-Younger analysis when law enforcement agencies had been directed immediately to institute prosecutions against the plaintiffs and were in the course of preparing those prosecutions.

${ }^{285}$ If that were the test of imminence, the only way a plaintiff could assure a federal forum for a constitutional challenge to a state criminal statute would be to test that statute before violating it, and that method would be available only if he could satisfy justiciability requirements at that stage.

${ }^{286} C f$. Younger v. Harris, 401 U.S. 37, $41-42$ (1971).

${ }^{287}$ Compare Zwickler v. Koota, 389 U.S. 241, 252-55 (1967), and Steffel v. Thompson, 94 S. Ct. 1209, 1215-16 (1974), with Golden v. Zwickler, 394 U.S. 103 (1969), and O'Shea v. Littleton, 94 S. Ct. 669, 675-77 (1974). See also note 259 supra.

${ }^{288}$ See Epperson v. Arkansas, 393 U.S. 97 (1968); Gardner v. Toilet Goods 
statute without having first to engage in criminal conduct. In the latter two situations, in which justiciable controversies can exist despite the absence of pending or imminent state proceedings, the "pending or imminent" line does produce a different result than a test focusing on whether the challenge is to a criminal enactment, and it allows those cases to be analyzed only in accordance with the Pullman doctrine without regard to the Dombrowski-Younger shift of presumption.

Decided cases are not altogether consistent with a "pending or imminent state criminal proceedings" limitation on the Dombrowski-Younger category. That line can explain the treatment of many cases. Baggett $v$. Bullitt, ${ }^{289}$ for example, was treated solely as a Pullman case although it involved an attack on a criminal statute, because the plaintiffs had not violated the statute they challenged. ${ }^{290} A F L$ v. Watson ${ }^{291}$ was treated as a Dombrowski-Younger case as well as a Pullman one. There the plaintiffs were in violation of the challenged statute and their prosecutions were, according to the complaint, "in process of being prepared."292 Lake Carriers' v. MacMul-

Ass'n, 387 U.S. 167 (1967); Adler v. Board of Educ., 342 U.S. 485 (1952); Euclid v. Ambler Realty Co., 272 U.S. 365 (1926); Pierce v. Society of Sisters, 268 U.S. 510 (1925); $c f$. Lake Carriers' Ass'n v. MacMullan, 406 U.S. 498, 504-08 (1972). But see Toilet Goods Ass'n v. Gardner, 387 U.S. 158 (1967); Poe v. Ullman, 367 U.S. 497 (1961); International Longshoremen's Union v. Boyd, 347 U.S. 222 (1954); United Public Workers v. Mitchell, 330 U.S. 75, 86-91 (1947).

289377 U.S. 360 (1964).

${ }^{290}$ Wisconsin v. Constantineau, see text accompanying notes 102-06 supra, escapes Dombrowski-Younger treatment because the plaintiff had not been subjected to a criminal sanction and was not threatened with any criminal proceedings. Insofar as the posting of her name is considered the equivalent of imposition of a criminal sanction, it had already taken place.

291327 U.S. 582 (1946).

292327 U.S. at 588. Zwickler v. Koota, 389 U.S. 241, 254 (1967), casts doubt on this analysis but does not squarely contradict it. The plaintiff Zwickler had been convicted of violating the statute he complained of when he distributed anonymous political handbills in the past. His conviction had been overturned on other grounds. He then sought declaratory and injunctive relief against future prosecutions for violating the same statute. He seemingly had not again violated the statute but expressed a desire to do so and claimed he was prevented from doing so by a fear of prosecution. 389 U.S. at 252-53.

In its treatment of the case, the Court did not make clear whether it would view it as a Dombrowski-Younger case or not. The court below had so treated it and had held the plaintiff had not satisfied the requirement of irreparable harm. The Supreme Court avoided deciding whether Zwickler was actually a Dombrowski-Younger case by holding that even if that conclusion were correct with respect to the plaintiff's request for injunctive relief, the same analysis did not apply to declaratory relief. See note 266 supra.

Under the analysis suggested in text, Zwickler should not be treated as a Dombrowski- 
$\operatorname{lan}^{293}$ is not a Dombrowski-Younger case because though the plaintiffs were in violation of the water pollution act they attacked and though the Michigan authorities had enforced the provisions of the act regarding pleasure craft, ${ }^{294}$ the Michigan authorities had not enforced the provisions pertaining to industrial boats like the plaintiffs', nor had they threatened to prosecute violations. ${ }^{295}$

Supreme Court opinions, however, rarely indicate any line of demarcation for the Dombrowski-Younger category or address in particular cases whether Dombrowski-Younger or Pullman treatment is proper. Moreover, they often do not disclose facts relevant to the proper treatment of the case-such as whether a criminal proceeding is imminent or indeed whether the plaintiffs have violated the statute they challenge -but instead talk simply of one doctrine in relation to a particular case without disclosing why it is the relevant one. Assuming that "pending or imminent criminal proceedings" is indeed the line demarcating the Dombrowski-Younger category, then Pullman itself is a case in which the Court's failure to discuss such issues creates doubt whether the case was properly handled. Neither the Supreme Court opinion nor the district court opinion is informative on the point, but it seems likely that in Pullman the complaining railroads were in violation of the Commission's order, since that order sought to alter a preexisting practice. Nor do the opinions state whether enforcement proceedings had been threatened, ${ }^{296}$ though the district

Younger case since the plaintiff had not engaged in the conduct he would be prosecuted for and accordingly no prosecution was imminent. See text accompanying notes 319-22 infra. Douglas v. City of Jeannette is like Zwickler in every respect except that there was more than an individual plaintiff; there was a class, and despite previous prosecution its members had engaged in further violations of the statute they challenged and had been threatened with further prosecution.

293406 U.S. 498 (1972).

${ }^{294} 336$ F. Supp. 248, 250 (E.D. Mich. 1971).

295 "Michigan authorities ... seek the cooperation of the industry in the implementation of its program and have not instigated, nor does it appear, threatened criminal prosecutions." Id. at 252.

${ }^{296}$ Pullman did involve a penalty, subjecting a violator to a possible fine of up to $\$ 5000$. Tex. Rev. Civ. Stat. AnN. art. 6476 (1926). Multiple violations were multiply cognizable, Gulf, Col. \& S.F. Ry. v. Texas, 246 U.S. 58, 60 \& 62 (1918). The Pullman enforcement proceeding appears to have been denominated civil, however, with civil rules of evidence prevailing. That the case was thus not purely "criminal" might explain why it was not treated as a Dombrowski-Younger case. See note 282 supra; cf. Gibson v. Berryhill, 411 U.S. 564, 576 (1973) (suggesting that the dividing line between Dombrowski-Younger and Pullman cases may be whether state law characterizes the proceedings as "quasi-criminal"). 
court opinion does disclose that a temporary restraining order against the order's enforcement was issued during the proceedings. ${ }^{297}$

The vice of Pullman is a failure to address these issues; it may indeed have been correctly treated. There are two cases, however, that were treated solely as Pullman cases in which it affirmatively appears that the facts would justify DombrowskiYounger treatment if pending or impending prosecutions is the test of that category. The district court opinion in Chicago $v$. Atchison, Topeka $\mathcal{E}$ Santa $F e R y .{ }^{298}$ suggests that the plaintiffs there had violated the statute of which they complained. Moreover, the city had threatened criminal prosecution. ${ }^{299}$ As in Pullman, however, a temporary restraining order against enforcement had been issued by the district court after commencement of the proceeding. Similarly, the district court opinion in NAACP v. Patty ${ }^{300}$ shows that the plaintiffs there were in violation of the statutes they challenged and also that prosecution had been threatened. The district court therefore treated the case as a Dombrowski-Younger one. It did find the irreparable harm requirement satisfied, though in doing so it applied a test seemingly less stringent than that the Court would have followed..$^{301}$ The Supreme Court, however, did not mention the possibility of Dombrowski-Younger treatment for the case ${ }^{302}$ and applied only Pullman analysis. ${ }^{303}$

The Supreme Court has recently decided several cases that appear to contain the opposite error, applying Dombrowski-

${ }^{297}$ Pullman Co. v. Railroad Comm'n, 33 F. Supp. 675, 676 (W.D. Tex. 1940).

${ }^{298} 136$ F. Supp. 476 (N.D. Ill. 1956), rev'd, 240 F.2d 930 (7th Cir. 1957), aff'd, 357 U.S. 77 (1958).

299357 U.S. at 81 .

${ }^{300} 159$ F. Supp. 503 (E.D. Va. 1958), vacated and remanded, 360 U.S. 167 (1959).

${ }^{301}$ Cf. Douglas v. City of Jeannette, 319 U.S. 157, 163-65 (1943); Spielman Motor Sales Co. v. Dodge, 295 U.S. 89, 95-96 (1935); \& Beal v. Missouri Pac. R.R., 312 U.S. 45, 50-51 (1941). Earlier the Court had followed a more lenient test closer to that of the district court. See Packard v. Banton, 264 U.S. 140, 143 (1924); cf. Ex parte Young, 209 U.S. 123, 161-63 (1908).

${ }^{302}$ It did refer to the district court's finding that threatened enforcement produced irreparable harm and said the finding was supported by the evidence. 360 U.S. at 178. It did not, however, appear to be thereby addressing the Dombrowski-Younger issue but instead seemed to state concern that the parties be protected during the Pullman abstention it ordered. That concern was satisfied by pledges state officials made during the course of the litigation not to proceed against the plaintiffs for conduct engaged in during the period they were testing the statutes. Id. at 179 .

${ }^{303}$ England v. Louisiana State Bd. of Medical Examiners, 375 U.S. 411 (1964), may also properly be a Dombrowski-Younger case, though only Pullman abstention was discussed or ordered. The Supreme Court did not rule on the validity of the abstention. 
Younger analysis in situations calling only for Pullman treatment. While those cases do not fit within the categorization this Article suggests for Dombrowski-Younger cases, they do not suggest any other workable classification either. Indeed, they do not recognize Dombrowski-Younger cases as a separate category at all; their common mistake is a failure to note any difference of approach between "Dombrowski-Younger cases" and other cases within the federal jurisdiction, most noticeably the difference in applying the irreparable harm requirement. Consequently the opinions proceed on the assumption that the only distinction to be made is between one group of cases in which it is proper to exercise federal jurisdiction and one group in which it is not.

In Steffel $v$. Thompson ${ }^{304}$ the petitioner sought declaratory relief $^{305}$ against a threatened application to him of Georgia's criminal trespass statute. While distributing handbills protesting American involvement in Vietnam on an exterior sidewalk of a shopping center, the petitioner had on two occasions left under threats by police that if he continued handbilling he would be arrested. On the second occasion, petitioner's companion had refused to leave and had been arrested and charged with criminal trespass.

In his complaint the petitioner alleged he desired to continue handbilling but that threats that if he did he would be arrested and prosecuted deterred him from doing so. The district court and the court of appeals denied relief. The Supreme Court reversed, Justice Brennan writing for a unanimous Court.

The Court found, first, that the petitioner's allegations did establish the existence of an actual controversy at the time he filed his action. His fears of prosecution were not "imaginary or speculative," 306 as both police testimony and his compan-

which was ordered by the district court. It appears that the plaintiffs had violated the criminal statute and that threats of enforcement had been made.

${ }^{304} 94$ S. Ct. 1209 (1974).

305 In the district court he sought injunctive relief as well. It was denied along with the declaratory relief. Becker v. Thompson, 334 F. Supp. 1386 (N.D. Ga. 1971). On appeal to the court of appeals the petitioner abandoned the request for injunctive relief. Becker v. Thompson, $459 \mathrm{~F} .2 \mathrm{~d} \mathrm{919,} 921$ (5th $\mathrm{Cir}$. 1972). The fact that injunctive relief was originally requested means that a three-judge court should have heard the case in the first instance, but the abandonment of the request for injunctive relief made the court of appeals' exercise of jurisdiction proper. $94 \mathrm{~S}$. Ct. at 1214-15 n.7. ${ }^{306} 94$ S. Ct. at 1215 (quoting Younger v. Harris, 401 U.S. 37, 42 (1971)). 
ion's arrest confirmed, and it was not necessary that he "first expose himself to actual arrest or prosecution to be entitled to challenge a statute that he claims deters the exercise of his constitutional rights." 307 The only question was whether the controversy continued until the present, given the lessening of American involvement in Vietnam, ${ }^{308}$ a question the Court directed the district court to resolve on remand.

The Court then proceeded to ask whether declaratory relief should have been precluded because the petitioner's attack was levelled at a state criminal statute. The lower courts had found relief inappropriate on grounds that Younger $v$. Harris "made it clear beyond peradventure that irreparable injury must be measured by bad faith harassment,"309 that bad faith could not be found here, and that though Younger's holding was limited in terms to situations in which a state prosecution was pending, its reasoning applied equally to threatened state proceedings. Likewise, the courts reasoned, Samuels v. Mackell ${ }^{310}$-holding that in situations where Younger made injunctive relief unavailable because of an absence of irreparable harm, declaratory relief should be equally unavailable-should apply equally to threatened criminal proceedings.

The Supreme Court's reversal was on the theory that "[n]either Younger nor Samuels . . . decided the question whether federal intervention might be permissible in the absence of a pending state prosecution," 311 and that those decisions should not apply when criminal proceedings were not pending because in that situation

federal intervention does not result in duplicative legal proceedings or disruption of the state criminal justice system; nor can federal intervention, in that circumstance, be interpreted as reflecting negatively upon the state courts' ability to enforce constitutional principles. In addition, while a pending state prosecution provides the federal plaintiff with a concrete opportunity to vindicate his constitutional rights, a refusal on the part of the federal courts to intervene when no state proceeding is pending may place the

${ }^{307}$ Id. at 1216 .

${ }^{308}$ Cf. Golden v. Zwickler, 394 U.S. 103 (1969).

${ }^{309}$ Becker v. Thompson, 459 F.2d 919, 922 (5th Cir. 1972).

310401 U.S. 66 (1971).

$31194 \mathrm{~S}$. Ct. at 1217. 
hapless plaintiff between the Scylla of intentionally flouting state law and the Charybdis of foregoing what he believes to be constitutionally protected activity in order to avoid becoming enmeshed in a criminal proceeding. ${ }^{312}$

Therefore, the Court concluded, when no state criminal proceeding is pending at the time federal intervention is sought, at least declaratory relief is not precluded, for it does not require the irreparable injury traditionally prerequisite to injunctive relief. ${ }^{313}$ The Court left open the question whether injunctive relief would be precluded on the facts of this case, ${ }^{314}$ since the petitioner had abandoned an earlier request for that remedy. 315

While the Court's result is clearly proper, its reasoning is problematic. A plain implication is that central to the result is a difference between the equitable requirement of irreparable injury and the requirements for declaratory relief. It cannot be simply a difference between the requirements for equitable and declaratory relief that explains which cases a federal court will hear, however, for in suits involving pending state prosecutions, requests for declaratory and injunctive relief are equally barred..16 More fundamentally, Pullman and other cases subjected solely to Pullman analysis involved injunctive relief and yet were deemed to have satisfied the equitable requirement of irreparable harm without a showing that state criminal processes could not adequately adjudicate the controversy. If, as the Court said, it recognized as an open question whether injunctive relief might be proper on the facts of Steffel, prèsumably without a showing of bad faith on the part of law enforcement officials, that is because it is not solely a difference between declaratory and injunctive requirements that explains the exercise of federal jurisdiction in Steffel. An injunction might be permissible in the circumstances of that case on either of two theories: First, the less stringent test of irreparable injury, not requiring a showing of inadequacy in the state forum but instead presuming in favor of the fed-

$312 I d$.

313 See id. at 1218-22.

${ }^{314}$ Id. at 1217. See also Allee v. Medrano, 94 S. Ct. 2191,2203 n.15 (1974).

315 See note 305 supra.

316 Samuels v. Mackell, 401 U.S. 66 (1971). 
eral forum, might be applicable and the case not be within "the Dombrowski-Younger category" at all. Alternatively, special circumstances might be required to justify the exercise of federal jurisdiction in the case without the test of special circumstances being as stringent as when state proceedings are pending. ${ }^{317}$ For example, the bad faith requirement usually prerequisite to the exercise of federal jurisdiction when a state prosecution is pending ${ }^{318}$ might not be deemed essential if the prosecution were not pending. This alternative would mean that Steffel, though not within a Younger category of cases (those involving pending criminal proceedings) was within the Dombrowski one (imminent state proceedings, still requiring showing of special circumstances for exercise of federal jurisdiction) and not in a category, like cases properly subjected only to Pullman analysis, where the presumption is in favor of federal jurisdiction.

On the facts of Steffel the first of these alternatives should be adopted and the case should not be subjected to DombrowskiYounger analysis at all. ${ }^{319}$ For the petitioner in Steffel . was seeking to enjoin a statute that would be applied to him only in the event that he engaged again in handbilling; the threats to prosecute were not for past conduct but for conduct the petitioner had yet to engage in. In that situation, to defer in favor of state criminal proceedings would require persons to subject themselves to criminal liability as a condition of attacking the constitutionality of the state criminal statute, a plainly undesirable result if, in the absence of criminal liability, there is nonetheless an extant case or controversy. ${ }^{320}$ Since no deference should be paid state criminal proceedings in a situation where the conduct to be charged has not yet occurred, a constitutional attack on the criminal statute brought at that time should proceed in federal court, unless Pullman requirements for abstention are satisfied.

The Court's analysis in Steffel does not, however, proceed along such lines. In addition to whether declaratory or injunctive relief is sought, a factor discussed above, the Court implies that the differentiating factor between cases in which federal jurisdiction is exercised and those in which it is not is whether

317 See note 280 supra.

318 Id.

319 See also note 292 supra.

${ }^{320}$ See note 287 supra \& accompanying text. 
state criminal proceedings are pending or merely threatened at the time the federal suit is commenced. While that distinction may be operative in some cases, ${ }^{321}$ it does not explain the difference in treatment between cases like Dombrowski and Pullman. The Court has failed to differentiate between two kinds of threatened state proceedings: those threatened for conduct that has already occurred and those threatened for conduct yet to be engaged in. If in Steffel the threat was to prosecute the petitioner for handbilling he had already done and, though state proceedings had not commenced when the federal suit was filed, state officials were in the course of preparing to prosecute, the case would resemble Dombrowski; under that holding more deference to state criminal proceedings would seem appropriate than in the case as it arose. ${ }^{322}$

$$
\text { Another case }{ }^{\mathbf{3 2 3}} \text { containing errors similar to Steffel is Speight }
$$

${ }^{321}$ See note 280 supra.

${ }^{322}$ It has not been clear whether the special circumstances required to justify the exercise of federal jurisdiction in that instance would be the same as in a Younger (pending state prosecution) situation or not. See notes 266 \& 280 supra. The Steffel holding purports to answer that question, saying at least as respects declaratory relief, a different and more lenient standard applies when the federal plaintiff wins the race to the courthouse. No doubt Steffel will be taken so to settle the question. See Allee v. Medrano, 94 S. Ct. 2191, 22012203 (1974). Query whether the Court would have so held, however, if it had been presented with a case properly within the Dombrowski-Younger category-if, for example, Steffel had been threatened with prosecution for acts already engaged in. Since the issue is the standard of special circumstances in that type of case, and Steffel is not that type of case, it should not be deemed dispositive of the issue despite the fact that the Court apparently thought it was involved there.

${ }^{323}$ A third 1973 Term case contains errors similar to Steffel. In Allee v. Medrano, 94 S. Ct. 2191 (1974), the plaintiffs, farmworkers, sought to enjoin as unconstitutional the enforcement of several Texas statutes, Texas PEN. Code ANn. art. 474 (1948) (breach of the peace) (since repealed); id. art. 482 (1948) (abusive language) (since repealed); id. art. 439 (1948) (unlawful assembly) (since repealed); Tex. Rev. CIv. STAT. ANN. arts. 5154(d) \& 5154(f) (1971) ("picketing" \& secondary picketing), and sought also to enjoin certain Texas law enforcement officials from interfering with their constitutional rights. They prevailed in the district court, and the Supreme Court affirmed, Justice Douglas writing for the five-man majority.

Justice Douglas first explained that a "case or controversy" was present, 94 $\mathrm{S}$. Ct. at 2197-98, then took up the subject of the decree enjoining state officials. After "not[ing] that this portion of the decree creates no interference with prosecutions pending in the state courts, so that the special considerations relevant to cases like Younger v. Harris . . . do not apply here," $i d$. at 2199-2200, Justice Douglas said, "Nonetheless there remains the necessity of showing irreparable injury, "the traditional prerequisite to obtaining an injunction' in any case." Id. at 2200 (citing Younger v. Harris, 401 U.S. 37, 46 (1971). He went on to say that irreparable injury was apparent from the "persistent pattern of police misconduct" that the case involved. 94 S. Ct. at 2200.

From the language quoted thus far, it is apparent that Allee v. Medrano, like Steffel, assumes that for purposes of the exercise of federal jurisdiction there are 
v. Slaton. ${ }^{324}$ There the three-judge district court had declined to exercise its jurisdiction because of a pending state civil enforcement proceeding. The Supreme Court avoided reaching the question whether Younger applied to civil as well as criminal enforcement proceedings, ${ }^{325}$ for subsequent to the district court's decision, the Georgia Supreme Court had declared unconstitutional the state statute under which the enforcement proceedings had been brought. The Supreme Court reasoned that

two categories of cases-those involving pending state criminal prosecutions and others-without regard to any distinction between cases like Dombrowski involving imminent state prosecutions and cases properly subject only to Pullman analysis where state prosecutions are neither imminent nor pending. The Court's failure to make the latter distinction is apparent in its comment that irreparable injury is invariably requisite to injunctive relief. It is unclear whether Justice Douglas is applying that requirement in the Pullman or the Dombrowski sense when he says the showing of persistent police misconduct satisfies it. It should be sufficient for the plaintiffs in Medrano to satisfy the less stringent test of irreparable harm applied in Pullman, since Medrano's injunction against Texas officials, which "[o]n its face . . . [did] not more than require the police to abide by constitutional requirements," id. at 2199 , did not involve pending or threatened prosecutions at all. The Court's citation to Dombrowski in making its irreparable harm argument, id. at 2200 , however, may indicate it viewed the requirement it was imposing as equivalent to the one in that case.

In the final part of his opinion, Justice Douglas addresses the propriety of the injunction against the Texas statutes. Since there was some confusion in the record concerning whether there were pending prosecutions, Douglas remanded for a finding on this question, saying Younger and Samuels apply only when pending state prosecutions are present (citing Steffel). A confusing factor in Justice Douglas' discussion of the issue is his reference to whether "there were pending prosecutions at the time of the District Court decision," id. at 2201, or whether there are pending prosecutions at the time of the remand, id. at 2202, whereas earlier cases dealing with pending prosecutions clearly have been concerned, for Dombrowski-Younger purposes, with their pendency at the time the federal suit was filed, e.g., Steffel v. Thompson, 94 S. Ct. 1209, 1217 (1974); Dombrowski v. Pfister, 380 U.S. 479, 484 n.2 (1965).

Another indication of a departure from settled practice in the Medrano opinion is contained in Douglas' statement, 'because we cannot determine with certainty whether there are pending prosecutions, or even whether the District Court intended to enjoin them if there were, the proper disposition is to remand the case to the District Court for further findings." 94 S. Ct. at 2202 (emphasis added). The implication that the result may differ according to whether the decree speaks in terms of enjoining a criminal prosecution or, instead, enjoining the criminal statute under which a prosecution pending against the federal plaintiff is brought is inconsistent with prior case law. See note 281 supra \& accompanying text; Roe v. Wade, 410 U.S. 113,126 (1973). No such distinction according to the wording of an injunction should be accepted, since once a state criminal statute is declared unconstitutional and its enforcement enjoined, any criminal prosecution proceeding under it is effectively interfered with.

A final point of interest in Allee v. Medrano is that while two of the statutes sought to be enjoined were civil statutes, the Court's opinion proceeds exactly as if all the challenged enactments were criminal. $C f$. notes 256 \& 278 supra.

32494 S. Ct. 1098 (1974) (unanimous per curiam decided after oral argument).

${ }^{325}$ See note 278 supra. 
appellants could obtain full relief in the state court proceeding merely by moving to dismiss the state action, in accord with state procedural rules, in light of ... [the Georgia Supreme Court's recent decision]. If that is the case, appellants could not now make any showing of irreparable injury by reason of the state court proceeding, and such a showing is of course required before the federal court could grant the equitable relief, apart from any special considerations involved in Younger v. Harris. . . . ${ }^{326}$

The difficulty with this reasoning is that its correctness depends upon whether civil enforcement proceedings are within the Dombrowski-Younger category at all-the question the Court purported not to decide. For if the case is wholly without the Dombrowski-Younger category, it is erroneous to apply as a prerequisite to injunctive relief an irreparable harm requirement that looks to the adequacy of state proceedings. ${ }^{327}$

Despite Steffel v. Thompson and Speight v. Slaton, there is a difference in treatment between cases like Dombrowski and those properly subjected only to Pullman analysis, though distinctions may also be drawn within the Dombrowski-Younger category between suits involving imminent and pending prosecutions. Whether a case is placed in the Dombrowski-Younger category or the Pullman category may well determinatively affect the exercise of state or federal jurisdiction. It is therefore both surprising and disturbing that Supreme Court opinions often seem oblivious to the fact that any two such categories exist; consequently, they neither address the demarcation of these categories nor reveal any clear pattern of where the line is drawn. If, as seems likely despite Steffel $v$. Thompson, it is pending and imminent state criminal proceedings in which the Court will presume in favor of the state forum, the Court should explicitly recognize its shift of presumption from other cases within federal jurisdiction and should attempt to explain why the shift is allowable in the face of congressional jurisdictional statutes. In any event, enunciation of an explicit line

32694 S. Ct. at 1099.

${ }^{327}$ The Court's result might be permissible anyway under the discretionary rule that when an ongoing state proceeding involves an issue presented to the federal court, the federal tribunal may in its discretion await the state outcome without regard to usual abstention principles. See note 256 supra. 
would provide the parties and the lower courts with more guidance than does the current amalgam of holdings, thus avoiding much of the wastefulness that currently occurs in determining whether the federal or the state forum should proceed with a controversy. ${ }^{328}$. Little can be said for retaining a category of cases of such uncertain scope and rationalea criticism applicable to the Thibodaux and administrative categories of abstention, as well as to this Dombrowski-Younger one.

${ }^{328}$ Perhaps also, depending upon what definition of "imminence" prevails, an explicit line drawn at imminent and pending state proceedings would often enable a state's attorney general to take advantage of the Dombrowski-Younger presumption by claiming an intent promptly to institute state criminal proceedings. 